\title{
Marine Archeological Survey of the Proposed Bolivar Ferry Dredge Spoil Pile Expansion Area, Galveston County, Texas
}

\author{
Mason D. Miller \\ Jeffrey M. Enright \\ Paul Sjordal
}

Follow this and additional works at: https://scholarworks.sfasu.edu/ita

Part of the American Material Culture Commons, Archaeological Anthropology Commons, Environmental Studies Commons, Other American Studies Commons, Other Arts and Humanities Commons, Other History of Art, Architecture, and Archaeology Commons, and the United States History Commons

Tell us how this article helped you.

This Article is brought to you for free and open access by the Center for Regional Heritage Research at SFA ScholarWorks. It has been accepted for inclusion in Index of Texas Archaeology: Open Access Gray Literature from the Lone Star State by an authorized editor of SFA ScholarWorks. For more information, please contact cdsscholarworks@sfasu.edu. 


\section{Marine Archeological Survey of the Proposed Bolivar Ferry Dredge Spoil Pile Expansion Area, Galveston County, Texas}

\section{Licensing Statement}

This is a work for hire produced for the Texas Department of Transportation (TxDOT), which owns all rights, title, and interest in and to all data and other information developed for this project under its contract with the report producer. The report may be cited and brief passages from this publication may be reproduced without permission provided that credit is given to TXDOT and the firm that produced it. Permission to reprint an entire chapter, section, figures or tables must be obtained in advance from the Supervisor of the Archeological Studies Branch, Environmental Affairs Division, Texas Department of Transportation, 125 East 11th Street, Austin, Texas, 78701 


\section{Marine Archeological Survey of the Proposed Bolivar Ferry Dredge Spoil Pile}

Expansion Area, Galveston County, Texas

by

Final

Mason D. Miller, Jeffrey M. Enright, and Paul Sjordal

Prepared for

Texas Department of Transportation-Environmental Affairs Division

CSJ: $7100-00-001$

Texas Antiquities Permit: 6272

Technical Report No. 19

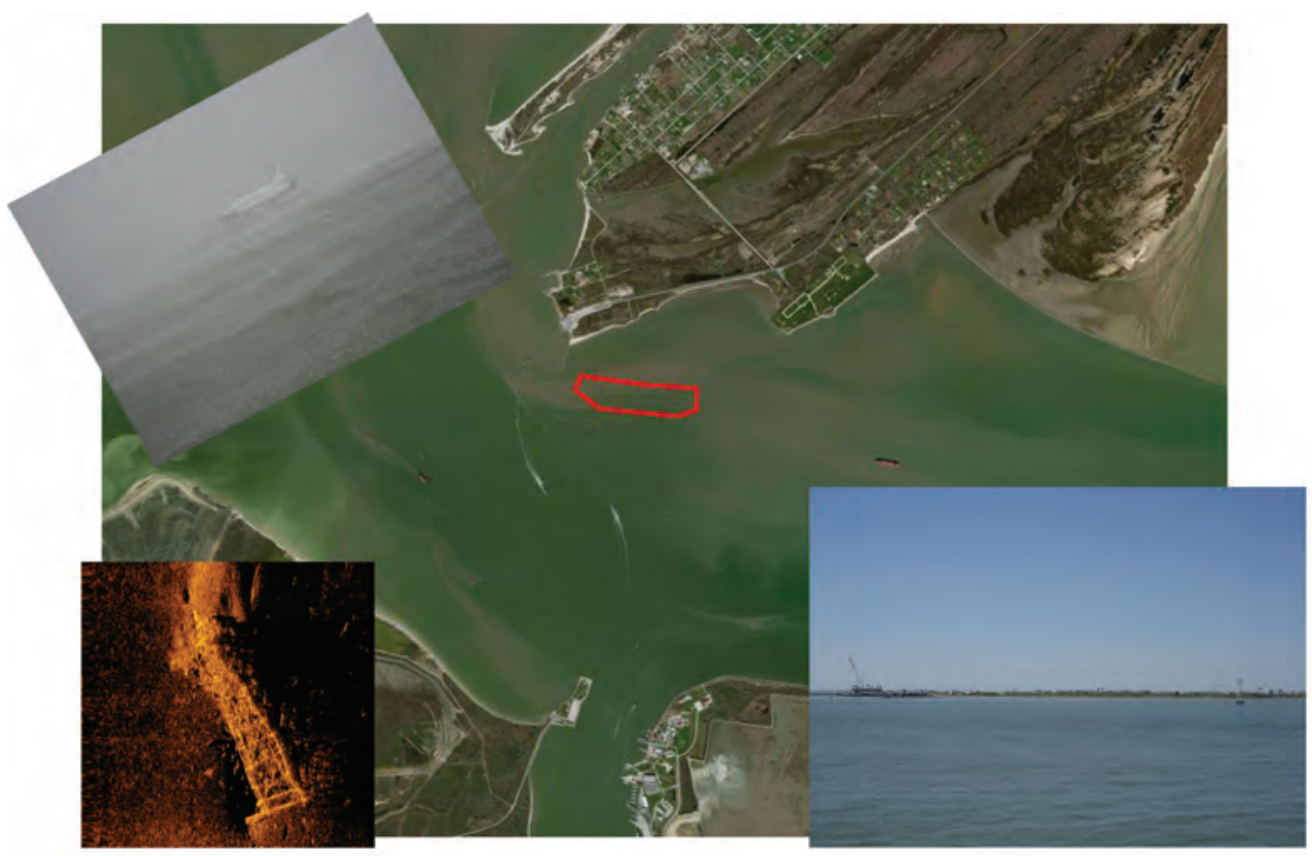





\title{
Marine Archeological Survey of the Proposed Bolivar Ferry Dredge Spoil Pile Expansion Area, Galveston County, Texas \\ Final
}

CSJ: 7100-00-001

by

\author{
Mason D. Miller, Jeffrey M. Enright, and Paul Sjordal \\ Marine Archeological Principal Investigator: \\ Jeffrey M. Enright, M.A.
}

Contract 57-1XXSA002

Work Authorization 57-107SA002

TxDOT Archeological Studies Program Report No. 146

Prepared for

Texas Department of Transportation

Environmental Affairs Division

Antiquities Permit No. 6272

by

AmaTerra Environmental, Inc.

and

Southeastern Archaeological Research, Inc.

AmaTerras

Technical Report No 19

August 2012 
This is a work for hire produced for the Texas Department of Transportation (TxDOT), which owns all rights, title, and interest in and to all data and other information developed for this project under Contract 57107SA002. Brief passages from this publication may be reproduced without permission provided that credit is given to TxDOT and AmaTerra Environmental, Inc. Permission to reprint an entire chapter, section, figures, or tables must be obtained in advance from the Supervisor of the Archeological Studies Program, Environmental Affairs Division, Texas Department of Transportation, 125 East 11th Street, Austin, Texas, 78701. Copies of this publication have been deposited with the Texas State Library in compliance with the State Depository Requirement.

Printed by Speedway Printing, Austin, Texas

Published by:

Texas Department of Transportation

Environmental Affairs Division

Archeological Studies Program

Scott Pletka, Ph.D., Supervisor

Archeological Studies Program Report No. 146

A. McGraw, Series Editor

and

AmaTerra Environmental, Inc.

Technical Report Number 19

ISBN \# 978-1-935545-13-2

AmaTerra Project No. 062-042

Cover photograph: Various images from the survey. 


\section{Abstract}

Archeologists from AmaTerra Environmental, Inc. (AmaTerra) and Southeastern Archaeological Research, Inc. (SEARCH; collectively the Team) conducted intensive underwater archeological remote sensing survey on behalf of the Texas Department of Transportation (TxDOT) on a proposed dredge spoil expansion area south of the Bolivar Peninsula at the mouth of Galveston Bay, Galveston County, Texas. The survey was required for compliance with the National Historic Preservation Act of 1966, as amended, due to dredge permits to be issued by the US Fish and Wildlife Service, and the Antiquities Code of Texas, due to its location on lands owned by a political subdivision of the State of Texas (the Texas General Land Office). Completed under Antiquities Permit 6272, the survey area includes the 51-acre dredge spoil expansion footprint and the original 16-acre dredge spoil pile (67 acres total). The archeologists utilized towed marine magnetometer and side-scan sonar survey along 12 parallel, 20-meter-interval transects to assess the full archeological Area of Potential Effects. The survey area was found to be littered with isolated modern metallic debris. Side-scan sonar imagery revealed a submerged surface that was generally flat with no indications of shipwrecks and a large oyster reef along the southwestern quarter. One large metallic feature located within the survey area (Anomaly M1) was identified as a fallen modern navigational sighting marker tower. None of the archeological survey data, sensor readings, or imagery from the proposed expansion area is consistent with expected signatures of historic-age shipwrecks. Archeologists did re-identify the previously-documented magnetic anomaly M44 that was recommended for avoidance or testing within the original dredge pile area. If the avoidance zone continues to be observed, it will not be impacted by the current undertaking. As such, the project is recommended to proceed with no Historic Properties, State Archeological Landmarks, or archeological sites impacted in accordance with guidelines outlined in 36 CFR 800 and 13 TAC 26. No sites were identified and no artifacts were collected during the course of the survey. Accordingly, all project-generated notes, forms, and other materials will be permanently curated at AmaTerra's office in Austin, Texas and SEARCH's office in Pensacola, Florida. 


\section{Table of Contents}

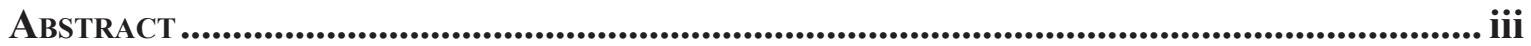

\section{Chapter 1.}

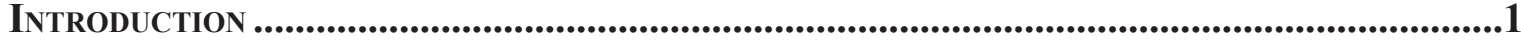

1.1 Description of the Existing and Proposed Facilities and Area of Potential Effects ......... 1

1.2 Management Summary and Regulatory Framework .................................................... 3

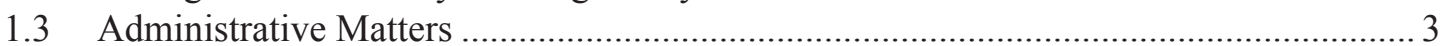

Chapter 2.

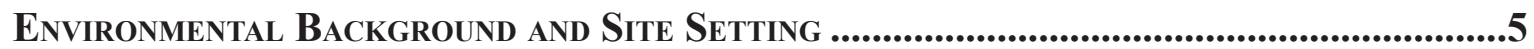

2.1 Geology

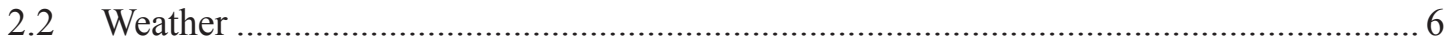

Chapter 3.

Cultural/Historical Background and Previous Investigations...................................7

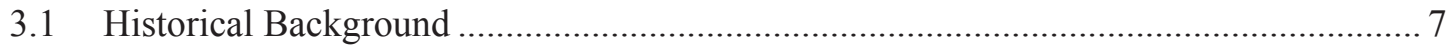

3.2 Previously Identified Shipwrecks and Historic Cartographic Features ......................... 15

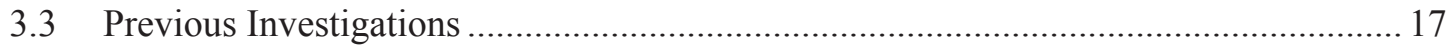

\section{Chapter 4.}

Research Design and Field Methodology ................................................................21

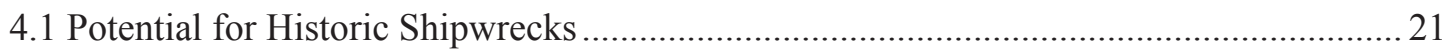

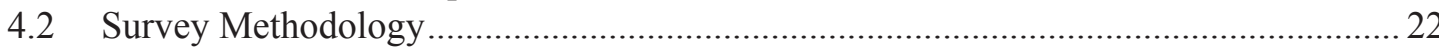

4.3 Remote-Sensing Data Processing and Interpretation Methodology ............................. 25

\section{Chapter 5.}

RESULTS OF FIELD INVESTIGATIONS ...................................................................................29

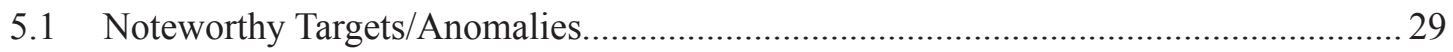

\section{Chapter 6.}

Conclusions AND RECOMMENDATIONS ...............................................................................31

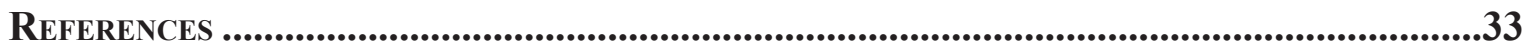

appendix a-Sensitive Cultural Resource Locational Information

appendix b-Antiquities Permit Documentation

APPENDIX C- Remote-SENSING SuRVEy LoG

APPENDIX D-Side-Scan Sonar CONTACT Report

appendix e- Bolivar Ferry Dredge Expansion Project Engineering Schematics 


\section{List OF Figures}

Figure 1. Bolivar Ferry Dredge Expansion Project Location Map..................................................... 2

Figure 2. Second Point Bolivar lighthouse ...................................................................................... 14

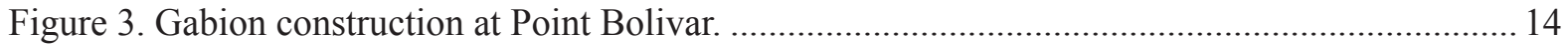

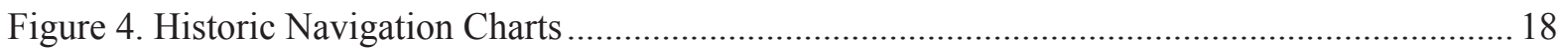

Figure 5. Map of previously conducted archeological surveys in the vicinity ................................. 19

Figure 6. General photo of the project area (facing northwest). Note sighting marker in right-center

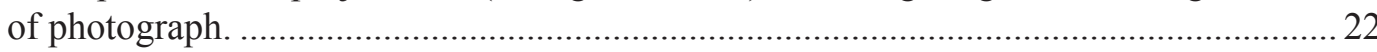

Figure 7. Photo of a Space Shuttle replica being towed into Galveston Bay during the brief, heavy thunderstorm that temporarily interrupted survey........................................................... 23

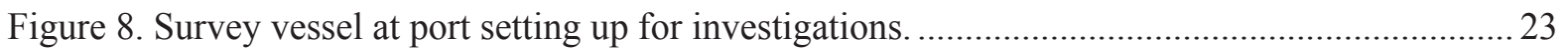

Figure 9. Survey transects followed to conduct marine investigations. ..............................................24

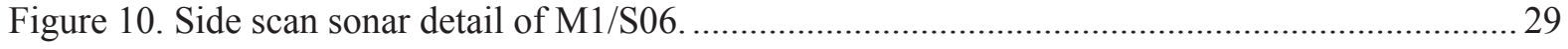

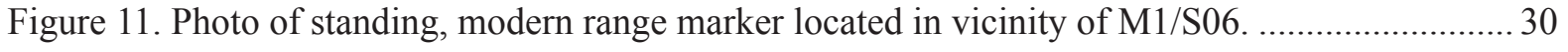

Figure A-1. Identified, previously recorded shipwrecks within one kilometer of the project area.....A-3

Figure A-2. Magnetometer survey contour map of the Bolivar Ferry dredge expansion survey

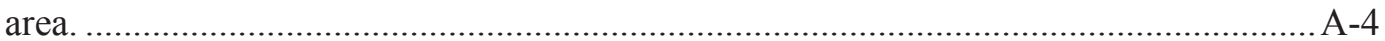

Figure A-3. Side Scan Sonar mosaic of the Bolivar Ferry dredge expansion survey area. ................ A-5

\section{LisT OF TABLES}

Table A-1: Recorded Shipwrecks within One Kilometer of Current Project Area 


\section{Chapter 1}

\section{INTRODUCTION}

From May 31st through June 1st, 2012, archeologists from AmaTerra Environmental, Inc. (AmaTerra) and Southeastern Archaeological Research, Inc. (SEARCH; collectively, The Team) conducted intensive maritime archeological remote sensing survey of the proposed 67-acre Bolivar Ferry Dredge Spoil Expansion Area in Galveston County, Texas. The work was conducted on behalf of the Texas Department of Transportation's Environmental Affairs Division (TxDOT-ENV) for National Historic Preservation Act (NHPA) and Antiquities Code of Texas (ACT) compliance under Texas Antiquities Permit 6272 (Figure 1). Remote sensing data were processed and analyzed and found to be devoid of any indications of historic-age shipwrecks, instead revealing a bottom that is littered by modern metallic debris and a large metallic lattice tower interpreted as a modern navigation range light. The Principal Investigator recommends that if a previously established avoidance zone is continued, the project may proceed with no Historic Properties or State Archeological Landmarks (SALs) affected.

\subsection{Description of the Existing and Proposed Facilities and Area of Potential Effects}

The Texas Department of Transportation (TxDOT) has proposed to conduct new dredging activities at the Bolivar Ferry Landing at Point Bolivar in Galveston County, Texas (Figure 1). Dredge spoil has been deposited at a previously surveyed and designated disposal area to the southeast of the dredging site but additional area is now required to deposit the remaining sediments from the current effort. The proposed dredge spoil expansion area is approximately $300 \times 700$ meters ( $984 \times 2,297 \mathrm{ft}$ ), covering a total area of about 51 acres ( 21 hectares; 67 acres including the 16-acre existing, previously-surveyed dredge spoil pile; see Figure 1, Appendices A and B). From available information, the undertaking's area of potential effects (APE) is defined as the three-dimensional limits of impacts that could result from a federal undertaking. For this undertaking the APE is defined as the 67 acres of proposed dredge spoils with the majority of those impacts limited to the proposed 51-acre expansion footprint. Impacts are anticipated to be limited to the submerged ground surface (or slightly below) that result from dumping dredged sediment. No private lands will be impacted by the proposed expansion and no PSLs or other facilities are anticipated.

Dredge excavation activities are not considered part of this project and are located within lands that have been previously surveyed. As such, survey coverage and recommendations do not have any relation to this activity. 


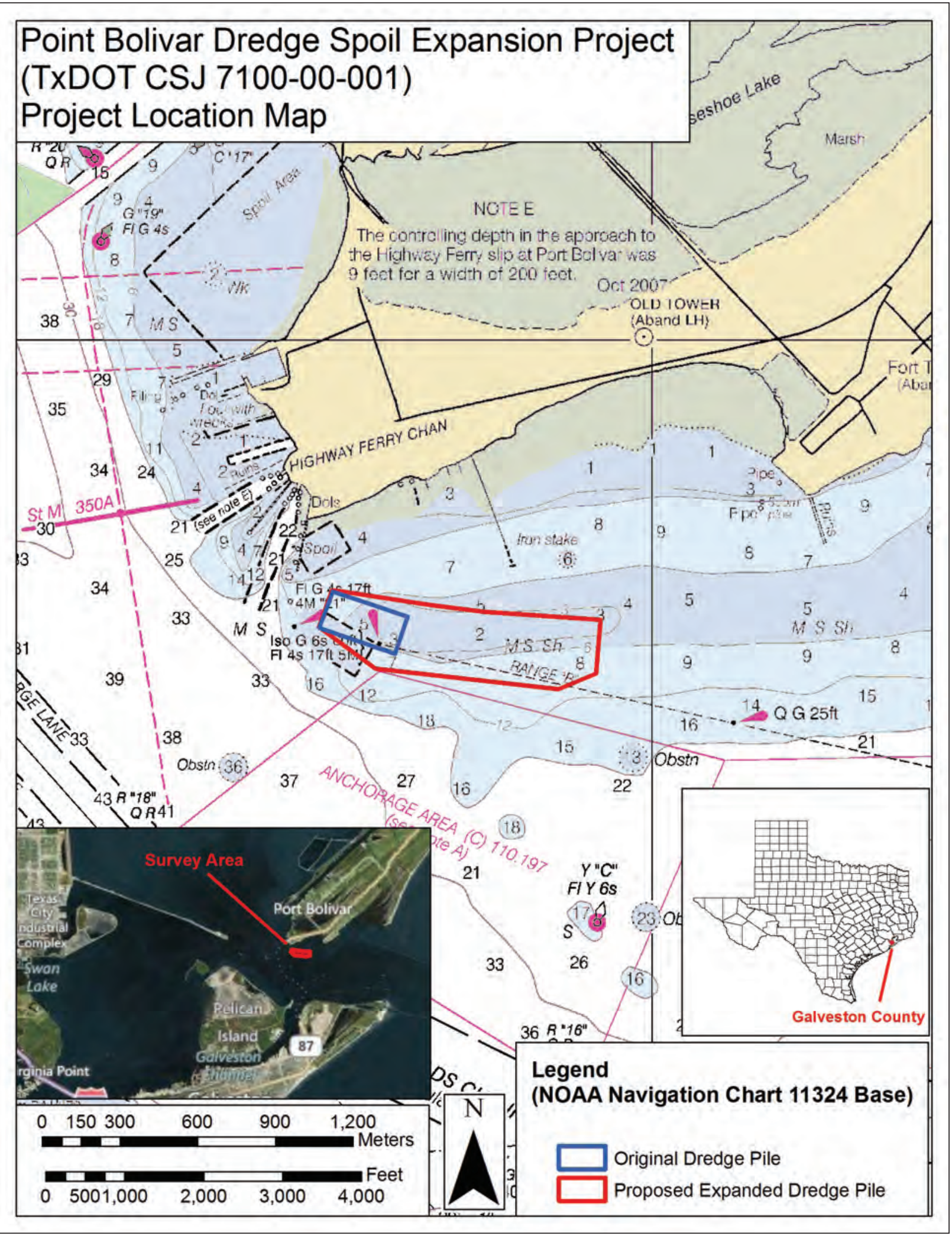

Figure 1. Bolivar Ferry Dredge Expansion Project Location Map 


\subsection{Management Summary and Regulatory Framework}

This survey was conducted on behalf of and sponsored by TxDOT-ENV and TxDOT's Houston District office. TxDOT has received a temporary, one-time clearance permit from the US Fish and Wildlife Service (USFWS) to deposit dredge materials at the expansion area location. The US Army Corps of Engineers' (USACE) Galveston office reviewed the proposed expansion plans and recommended that the area be archeologically surveyed prior to use for compliance with Section 106 of the National Historic Preservation Act of 1966, as amended. This survey would assess the undertaking's potential for impacting submerged historic properties (cultural resources considered eligible for listing on the National Register of Historic Places [NRHP]; letter Kimberly McLaughlin to Pat Henry 2/17/2012). For Section 106 purposes, USFWS is considered the Lead Federal Agency. Additionally, this dredge spoil pile is located within a state-owned (Texas General Land Office [GLO]) tract of submerged land (GLO Tract 136a) identified as a high-probability area for shipwrecks. Accordingly, the project is also subject to archeological resource regulatory oversight through the Antiquities Code of Texas (ACT). Known significant shipwrecks and unidentified significant magnetic anomalies are located nearby. In initial project coordination, TxDOT received a similar recommendation for survey from the State Marine Archeologist at the Texas Historical Commission (THC). The Team conducted the remote-sensing survey for the Point Bolivar Dredge Spoil Expansion Project following methodology specified in the Texas Administrative Code (Title 13, Part 2, Chapter 28, Rule 28.6). All survey work was conducted under Antiquities Permit 6272.

\subsection{Administrative Matters}

SEARCH maritime archeologist, Jeff Enright, served as the Principal Investigator while AmaTerra archeologist, Mason Miller, served as the underwater Project Archeologist. SEARCH archeologist Drew Roberts fulfilled the remaining staffing duties. All work was conducted between May 31st and June 1st, 2012, requiring approximately 36-person hours to complete.

No sites or artifacts were observed or collected during the course of investigations. All records, photographs, and notes will be permanently curated at AmaTerra and SEARCH's offices in (respectively) Austin, Texas and Pensacola, Florida.

Succeeding sections of this report include a discussion of the project setting and environmental, cultural, and historical background. The field methods and research goals employed in the survey are then discussed, followed by a detailed description of the results of field survey. The report ends with regulatory conclusions and recommendations based upon those field findings. 


\section{Chapter 2 \\ ENVIRONMENTAL BACKGROUND AND Site Setting}

This discussion of the environmental background of Galveston Bay focuses on the natural processes contributing historically to vessel loss and shipwreck preservation-weather and geology. Similar discussions have been presented previously in cultural resources management reports.

\subsection{GeOLOGY}

Galveston Bay lies within the Gulf Coastal Plain physiographic province and is the largest estuarine system in Texas. The bay covers approximately $600 \mathrm{mi} 2(1,554 \mathrm{~km} 2)$ and averages 7.0-9.0 feet (ft) (2.1-2.7 meters [m]) deep (Leatherwood 1996:53). The bay formed between 10,000 and 3,500 years before present (BP) following the Wisconsinan glacial episode (ca. 18,000-120,000 BP). Rivers incised valleys along the Texas coast as sea level fell during the Wisconsinan glacial episode. This created the Trinity/Sabine incised valley beneath Galveston Bay, Trinity Bay, Sabine Lake, and the near shore portion of the Gulf of Mexico (Fisk 1944). As glaciers retreated, sea level rose in the Trinity/Sabine valley during several flooding events, shorelines migrated, and the bay reached its approximate present depth towards the end of this period. Starting around $4500 \mathrm{BP}$, longshore currents and waves transported eroded sands southwestward and formed spits and bars offshore from Galveston Bay (Fisher et al. 1990). Eventually, sedimentation accumulation resulted in the formation of Bolivar Peninsula, Galveston Island, and Follets Island. These barrier islands help buffer oceanic processes such as tides, currents, and waves within the bay.

Galveston Bay sediments are dominated by Pleistocene (1.8 million-10,000 BP) and Late Holocene (4500-2800 BP) deposits. Pleistocene sediments, regionally referred to as Beaumont clay, were deposited in two depositional systems, fluvial-deltaic and barrier-strandplain, and consist of sands, silts, and muds (Fisher et al. 1990). Holocene sedimentation, consisting of sand and mud deposits, backfilled the incised valleys and valley margins between ca. 10,000 and $2500 \mathrm{BP}$ as sea level rose (Bernard et al. 1962). Recently, currents, eroding streams, and urbanization have altered the natural drainage of the modern bay-estuary-lagoon system and increased deposition of sediment (Fisher et al. 1990). Localized shoals were created throughout the bay as early Texas entrepreneurs and the Federal government placed dredged material along the margins of navigation channels.

Although the presence of barrier islands helps protect Galveston Bay from extreme oceanic forces, its relatively shallow water, localized shoals, and oyster reefs created treacherous conditions for historic mariners, as they do for modern mariners. Addressing the effect oyster reefs had on navigation historically, one maritime historian comments, "the edibility and 
profusion of oysters led to their frequent mention by travelers, and in some places the oyster population was so prolific that actual reefs of oysters were formed to create yet another hazard to navigation" (Francaviglia 1998:16). Once wrecked in Galveston Bay, the lower portion of a vessel would tend to sink into the Holocene sediments, while continuous sedimentation builds around the shipwreck as a result of erosion and storm activity. It is possible that a substantial portion of a shipwreck in Galveston Bay will become buried given an adequate amount of time. Buried in sediment, shipwreck remains will experience a higher level of preservation in a more anaerobic environment. Moreover, the buried portions are less likely to fall victim to plunder or destruction as a navigation hazard.

\subsection{WEATHER}

Extreme weather in the forms of hurricanes, strong tropical storms, and northers also likely contributed to historic vessel loss. Galveston Bay is located within the Upper Coast climatic region, which includes both tropical and temperate zones. Severe weather in the region can include hurricanes in the Gulf of Mexico during the months of June through November. A hurricane creates dynamic wind and current conditions within the bay. Strong counterclockwise winds stack water on the north side of the bay in front of the storm, while a southwestward current is generated along the shoreline that flushes water and sediment through the bay's tidal passes and storm channels on the backside of the storm (Fisher et al. 1990). As the storm passes inland and weakens, water stacked on the north side of the bay drains quickly through the tidal passes and storm channels.

Strong storms generated by cold polar air masses forced south over the warm waters of the Gulf of Mexico ("northers") occur in the region from October to April. The most powerful northers can produce gale force winds, amplify ebb tide velocity through Bolivar Roads, and generate longshore drift. Straight trajectory winds can last for several days generating waves as high as $30 \mathrm{ft}(9.1 \mathrm{~m})$ in the Gulf of Mexico (Rosendal 1965). 


\section{Chapter 3 \\ Cultural/Historical Background and Previous Investigations}

\subsection{Historical BaCkground}

The purpose of the following narrative is not only to present the maritime history of Galveston Bay, but to characterize the potential for historic shipwrecks in the vicinity of the project area. Knowledge of the types and frequency of maritime traffic within Galveston Bay throughout its recorded history will provide insight into the probability for shipwrecks during different periods.

\subsubsection{European Exploration and Colonization, 1500-1800}

The historian and author Robert S. Weddle has researched and written numerous books on Spanish and French colonial history. The following narrative of the maritime history of Galveston Bay from 1500 to 1780 is summarized from Weddle's exhaustive trilogy on the European exploration of the northern Gulf of Mexico: Spanish Sea: The Gulf of Mexico in North American Discovery, 1500-1685 (1985); The French Thorn: Rival Explorers in the Spanish Sea, 1682-1762 (1991); and Changing Tides: Twilight and Dawn in the Spanish Sea, 1763-1803 (1995).

The Panfilo de Narváez expedition of 1528 provides the first documented account of European contact on the Texas coast. During their explorations into the Gulf of Mexico, a storm separated and shipwrecked some of the expedition ships upon an island that many scholars believe to be either modern day Galveston Island or Follet's Island. Spain ignored the region for the next 150 years until the French explorer René Robert Cavelier Sieur de La Salle mistakenly wandered into the area in 1685 looking for the Mississippi River. La Salle's expedition provides the first European documentation of Galveston Bay. News of the French incursion reached Spain in 1686, emphasizing the lack of interest and knowledge of the northern Gulf of Mexico coastal province, as well as instilling a fear that their archenemy was gaining a foothold in Spanish territory. This spurred expeditions to locate and clear the French intruders and launched what Weddle (1991:68) refers to as the "...most intense coastal reconnaissance ever made in the Gulf of Mexico."

The first expedition, led by captains Martin de Rivas and Pedro de Iriarte, sailed on December 25, 1686, from Veracruz aboard two shallow draft piraguas. The Rivas-Iriarte expedition entered San Luis Pass and West Galveston Bay in the spring of 1687 and named it Santa Suzana. Two miles further up the coast, they arrived at the mouth of Galveston Bay, which they named Rio Bajo (Shoal River) due to the shoals at its mouth. The piraguas entered Galveston Bay and reconnoitered as far north as modern day Eagle Point. 
French interest in La Salle's claim to Bay Saint-Bernard (Matagorda Bay) increased during the War of the League of Augsburg (1688-1697) (incorporating King William's War on the North American continent) and the fight with Spain over the Texas-Louisiana frontier. New French exploration of the region continued in 1719 with an expedition commanded by Gervais de La Gaudelle. La Gaudelle overshot his destination in Louisiana and ran aground near the mouth of Galveston Bay. A group of sailors abandoned ship in order to travel overland for aid, only to be left behind by the commander once his ship was freed. Stranded, the sailors struggled to survive on the shores of Galveston Bay with what meat they could kill and what oysters they could collect from their canoe. A single sailor survived among the Indians of Galveston Bay until 1721 when he was returned to Louisiana. Next, Jean-Baptiste Bénard Sieur de La Harpe commanded an expedition in 1721 to establish a French garrison at Matagorda Bay. The expedition landed at Galveston Bay in the summer of 1721, mistaking it for Matagorda Bay.

The Seven Years' War (1756-1763) (incorporating the French and Indian War on the North American continent) brought an end to French occupation in America, and thereby Spain's feud over the border with Louisiana. However, during the conflict England established a foothold on the continent and in the northern Gulf of Mexico. At the same time, Spain entered an "Age of Enlightenment" for scientific knowledge. Both circumstances combined to spark Spain's geographical awareness and manifest “...a concern for exploration not seen since its determined search for La Salle's Texas colony in the previous century” (Weddle 1995:75).

Spain joined the American colonists' struggle for independence from Great Britain in 1779. Spain's goal, which would benefit them as much as the Americans, was to drive the British out of the Gulf of Mexico. War with England extended operations into the Gulf of Mexico and underscored Spain's lack of security along the Texas coast and in the strategic Gulf. The same year as Spain's declaration of war, Athanase de Mézières, a French officer who had entered Spanish service in 1769 as an Indian agent, prepared a report in which he stressed the need for exploration of the Gulf Coast. Another report late in the century prepared by pilot Manuel Laso de la Vega remarked that coastal Indians engaged in trade with Anglo-American schooners in Galveston Bay. Spain's only knowledge of Galveston Bay, of which Laso de la Vega later opinioned was the best bay on the entire coast, was that it harbored the mouths of the Trinity and San Jacinto rivers.

By the late 18th century, the Spaniards had explored and settled much of the Gulf of Mexico, except the Texas coast. The Gulf campaign during the American Revolutionary War and the reports of Mézières' and Laso de la Vega emphasized the need for more accurate nautical charts of the region and the underutilization of the Texas resources. In part to remedy the situation, one final maritime expedition in the 18th century, led by José Antonio de Evia, was sent to explore the Texas coast in the autumn of 1783. In July 1785, the Evia expedition sought shelter in Galveston Bay just inside San Luis Pass. Evia's expedition explored the area as far as half a dozen leagues up Trinity Bay, took soundings, and created a chart of the bay. It was this expedition that first provided the name Galveston Bay to the water body. 


\subsubsection{Piracy and Port Development under Mexican Rule, 1800-1836}

Spain's neglect of the Texas coast fostered the growing problem of piracy in the early 1800 s. One French buccaneer, Louis Michel Aury, took up residence on the Texas coast early in the 19th century and waged war against Spanish shipping. In 1816, Aury conspired with some New Orleans associates who planned a Mexican rebel port on the Texas coast as part of their revolt against Spain. Aury lost several prize vessels while attempting to enter Galveston Bay but still was able to establish his rebel port. He was named resident commissioner and conducted his privateering activities out of Galveston until the spring of 1817, when he left on a New Orleans backed expedition to seize Texas from Spain. While away, the pirate Jean Lafitte seized the port of Galveston and established his own rebel government and privateer base. Lafitte used a dozen schooners and brigs to harass mainly Spanish merchant vessels (Pratt 1954:56). Not until 1821 did U.S. backed interests force Lafitte out of Galveston.

Mexico won its independence from Spain in 1821 and opened Texas to entrepreneurs, empresarios, and settlers like Stephen F. Austin. This new influx of people, coupled with the patrolling Mexican Navy, effectively subdued piracy along the Texas coast for some time. Entrepreneurs set their sights on Texas and focused on turning Galveston into a major seaport for the shipment of cotton to England. Mexican support followed, when in 1825, the government voted to open a major port in Galveston and establish a customs house (Barker 1924:417). Cartographic knowledge of the coast followed the development of Texas and in 1826 Austin commissioned a printed map of the region. The map noted that "...the landing place most frequently used is Trinity Bay or Galvestown [sic] to take the Cíbola Creek [Buffalo Bayou] by which ships up to 100 tons burden can come up within 22 leagues off the Villa of Austin" (McClean 1975:461). Austin's map helped develop Texas maritime trade via the passes and bays that accessed the rivers and the interior (Francaviglia 1998:92).

Illicit maritime activity was curtailed under Mexican rule, but never ceased entirely. Contraband continued to be moved into Texas due to the "many anchorage points that schooners could slip into and out of virtually undetected" (Francaviglia 1998:105). Austin attempted to properly regulate all maritime trade but was unsuccessful. In an attempt to stem illegal trade, the Mexican Navy increased activities along the Texas coast. The heavy hand of the Mexican government against illegal trade eventually planted the seed for Texas revolution. Tensions increased along the coast in 1834, when several Mexican Navy vessels arrived at Galveston Bay to disband a militia at Anáhuac (Francaviglia 1998:108). In response to the presence of the Mexican Navy along their coastline, Texans organized the first Texas Navy. The fledgling armada gained control of the sea from Mexico in the spring of 1836. In part due to the aggressive actions of the Texas Navy, Sam Houston secured independence for Texas that same year. The first Texas Navy lasted only until 1837, falling victim to a financially overextended republic. A second Texas Navy was established and for a time resided at Galveston.

\subsubsection{Growth and Prosperity in the Republic, 1836-1845}

Galveston prospered under the Republic and became Texas' most important port city. Many European immigrants arrived at the city and built its population to a thriving 5,000 inhabitants 
by the end of the 1830s. "Without question, Galveston was the most promising and rapidly growing port in the Republic of Texas. Galveston's growth can be attributed to its geographic location, which included a harbor behind a fairly open pass, proximity to the communities developing inland in the vicinity of Houston, and proximity to New Orleans" (Francaviglia 1998:144).

The destinations of many immigrants were the growing shoreline communities of Galveston Bay. As immigrants arrived, populations along Buffalo Bayou and the Trinity, San Jacinto, Brazos, and Colorado rivers produced exports like cotton, which were transported to Galveston via steamboat. The growth and success of the Galveston Bay communities helped the port of Galveston become the Gulf of Mexico terminal for the territories between the Mississippi River and the Rocky Mountains, and their main outlet to the world's oceans (Young 1997:3).

\subsubsection{Steam Opens the Interior}

With the advent of steam-powered vessels it was not long before entrepreneurs, like Clopper in Harrisburg, realized the potential of river navigation in Texas. Clopper remarked (1828) that goods and passengers could be brought closer to the interior settlements by a small expense to render the rivers navigable and open to small steam vessels. "If, by the mid 1820 s, enterprising European Americans intuitively recognized and began to promote the potential of the rivers for steam navigation, their early writings were to prove prophetic in light of aggressive maritimerelated developments that would soon open up the province of Texas to a steady flow of European Americans" (Francaviglia 1998:97).

Steam powered vessels revolutionized maritime traffic and were seen more frequently sheltered in the ports and bays of the Republic loading and offloading goods and passengers faster and cheaper. Steamships became a regular site in Texas waters starting in the late 1830s with steam packets of the Charles Morgan and Mallory lines servicing Galveston and plying the Texas waters for more than 40 years. Steamships provided coastal trade to and from Galveston, while shallower draft steamboats bridged the gap between the gulf port and the communities along the shore and rivers of Galveston Bay. Steamboats began testing navigation on the San Jacinto and Trinity rivers beginning in the 1830s. In 1838 it was reported that a steamboat ascended $350 \mathrm{mi}(563 \mathrm{~km})$ up the Trinity River, and in 1840 it was reported that a steamboat travelled down the Trinity from the town of Alabama to Galveston, a distance of $500 \mathrm{mi}(805 \mathrm{~km})$ (Block 1995:181; Francaviglia 1998:133). Much interest was sparked during the 1840s at the ability of steamboats to depart Galveston and run up Buffalo Bayou to Houston (first established in 1837) and up and down the Trinity River.

\subsubsection{War, the Coming of the Railroad, and Dominance in the Bay Shifts, 1845-1900}

Texas was annexed into the Union in 1845, while Galveston continued to boom in the 1840 s and 50s as the premier port of Texas. Trade between Galveston and far away cities like New Orleans, Mobile, Savannah, Newport News, Philadelphia, New York, and Boston helped the 
port city and the interior communities of Galveston Bay continue to develop rapidly during the mid-19th century. Development brought an increase in the number of small schooners, sloops, and barges plying the waters of Galveston Bay to reach the inland rivers. A wide variety of sail and steam vessels serviced ports like Galveston by carrying goods and passengers to and from the inland communities and those farther down the Gulf Coast (Francaviglia 1998:171-172).

Vessel traffic through the entrance of Galveston Bay was so busy that the federal government built a light house on the tip of Point Bolivar to prevent shipwrecks. The light house was used in conjunction with a light boat located offshore to navigate the entrance of the bay. The original lighthouse that was built in 1852 was destroyed by Confederates during the Civil War to prevent Union vessels from using it as an aid to navigate the entrance to Galveston Bay (Daniels 2012).

\subsubsection{American Civil War: The Battle of Galveston}

The American Civil War descended upon Galveston on the evening of July 2, 1861, with the appearance of a Union steamer to initiate a blockade of the city. "Given Galveston's strategic importance and proximity to the prosperous hinterland of slave-holding East Texas and beyond, it is no surprise that this entrepôt was singled out for blockading by the federal forces soon after the war began" (Francaviglia 1998:191). The Union Navy blockaded Texas ports in an attempt to halt Confederate maritime commerce in the Gulf of Mexico.

"After Mobile and New Orleans were captured, Galveston became one of the only major Southern ports still in Confederate hands. It therefore became an increasingly prominent port for vessels engaged in the lucrative (if somewhat risky) practice of running the blockade" (Cotham 1998:168).

War materials and luxury items were brought into the city, while cotton was being shipped out aboard fast, steam-powered blockade runners. Approximately 87 percent of the steamers that attempted the blockade out of Galveston were successful (Price 1951:271).

Union forces captured Galveston in the autumn of 1862 and utilized it as a base of operations on the Texas coast. In response, General Magruder of the Confederate army enlisted Consulting Engineer Caleb G. Forshey to design an attack to take back the city. Magruder, stationed in Houston, combined Forshey's proposed nighttime land and sea attack with Captain Armand R. Wier's recommendation to place artillery units on steamboats, and set about preparing plans. For the naval attack, Magruder enlisted the services of steamboats previously used in the Galveston to Houston trade that were a regular site at Galveston and Houston wharfs (Cotham 1998:105-107). Union forces discovered the combined Confederate land and sea attack in Galveston Bay in the early morning hours of New Year's Day 1863. The naval battle was intense and ended in a defeat of the Union Navy and a surrender of the Federal ground forces. Galveston would not witness Union vessels at its wharves again until June 2, 1865, when Confederate authorities surrendered the Army of the Trans-Mississippi. "This final act in the failure of Southern independence occurred in the Confederacy's last major unoccupied port" (Frazier 1998:115). 


\subsubsection{Houston Rising}

By the turn of the century the Port of Galveston was cluttered with vessels registered all over the world. The city had climbed to second (behind New Orleans) in the amount of cotton exported, while the volume of other exports, like wheat, corn, and cattle, increased significantly (Young 1997:196). Pleasure crafts, yachts, and fishing vessels (commercial and private) plied the waters of Galveston Bay, while the fishing industry thrived both in the opens waters of the Gulf of Mexico and inside Galveston Bay. Shipyards were operating in Galveston Bay by 1880 constructing shallow draft sloops, schooners, tugs, and steamboats that operated in the maritime trade of Texas' shallow bays and rivers (Bricker 1998:4,10). The Industrial Revolution brought improvement in maritime transportation to Galveston in the late 19th century, like steel hulls and screw driven steamships.

Galveston was now the largest city on the Texas coast; however, Houston's population was growing rapidly and developing as the gateway to east Texas. Houston's access to the Gulf of Mexico, via Buffalo Bayou and Galveston Bay with the use of shallow draft vessels, ensured its growth. Two transportation improvements in the late 19th and early 20th centuries shifted power forever in Galveston Bay: the creation of permanent navigation channels and the railroad. Both ports stimulated the growth of the railroads for faster and cheaper service to the interior of the country. The combined services of maritime and rail transportation through ports like Galveston and towns like Houston stimulated coastal and oceangoing shipping and opened Texas to development and trade (Francaviglia 1998:183-184). However, the railroad not only stimulated growth and prosperity in the port towns but ultimately doomed riverboat navigation in the late 19 th century.

Houston had become a major rail center and maintained its own port facilities. Getting to and from Houston via Galveston Bay however, still remained difficult in the mid-19th century. Hazards to navigation included the bar at the Galveston entrance channel; Red Fish Bar, which was a shell reef that stretched east to west across the middle of the bay with a depth of only 4.0 $\mathrm{ft}(1.2 \mathrm{~m})$ across the top; Clopper's Bar near Morgans Point; and finally snags and logs in the bayou. "Running aground on this reef [Red Fish Bar] was an almost predictable occurrence in the course of a trip to Buffalo Bayou" (Alperin 1977:92). Galveston's inadequate railroad connections and Houston's superior rail service led one entrepreneur, Charles Morgan, to bypass Galveston and cut a channel in the 1870s directly from the Gulf of Mexico to Houston, via Buffalo Bayou. Houston, not Galveston, was now the terminus for the Morgan and Mallory steamship lines.

Galveston did not give up easily. In order to compete with Houston, Galveston attempted to improve its rail connections and access to and from the Gulf of Mexico. Natural sand bars occurred at the inshore and offshore portions of the pass into Galveston Bay in an otherwise deep entrance channel to the city. The difficulty crossing the bar into Galveston Harbor, despite being the best entrance on the Texas coast, became apparent in the 1840s. Through a series of congressional appropriations, delays, and redesigns the entrance channel was deepened and stabilized near the turn of the century through the construction of jetties and channel dredging. This successful lobbying for completion of Galveston's jetties and deepening of its 
harbor channel, combined with a push for better rail connections, created a boom in shipping exports and ensured the city's preeminence as a Texas port until century's end (Francaviglia 1998:263-264).

Galveston's improvements at the end of the 19th century briefly jeopardized the lightering traffic to Houston as deep draft vessels could now access the city of Galveston. Houston responded early in the 1900s with the government funded Houston Ship Channel, which was completed in 1914 to a depth of $25 \mathrm{ft}(7.6 \mathrm{~m})$ and a width of $150 \mathrm{ft}(46 \mathrm{~m})$ (Alperin 1977:100-102). Additional navigation improvements completed in Galveston Bay that promoted maritime commerce include a channel to Texas City from Galveston Harbor (1896), the Intracoastal Waterway between the Mississippi River and the Rio Grande (1949), and channel access to Trinity Bay (1960) (Alperin 1977).

The transfer of power to Houston was solidified by Mother Nature in 1900 when a hurricane devastated the city and population of Galveston. The 1900 hurricane, additional ship channel construction in Galveston Bay, Houston's location close to the recently discovered oil fields in east Texas, and the increased ship construction in the east Texas cities of Orange and Beaumont shifted the balance permanently to Houston. By 1920 Houston was becoming Texas' major port; a position that would remain throughout the twentieth century (Francaviglia 1998:266-267).

\subsubsection{Bolivar Peninsula}

While Galveston, Houston, and nearly every town and city on Galveston Bay thrived with increased trade and commerce, Bolivar Peninsula remained largely unpopulated for most of its history. In the early nineteenth century the peninsula was used mostly by smugglers trying to avoid the customs house at Galveston. They would sail to the east end of the peninsula and unload their cargo, transport it across the quarter mile strip of land and load again onto waiting ships in Rollover Pass (Wiggins 1990:40). The first permanent settlement attempt was undertaken in 1838 by an English settler named Samuel Parr. He claimed the western five miles of Bolivar Point and named it Parrsville. Following Parr's comprehensive survey of the land, the Republic of Texas granted his claim. Almost immediately, Parr began selling off plots of his newly acquired land. He sold 960 acres to his partners William Lawrence and Archibald Wynn (Wiggins 2012). For the next several decades the peninsula was settled by American and immigrant families, but never reached the population size seen in Galveston just a few miles to the west.

Throughout the nineteenth century few individuals and families settled Bolivar Peninsula. Most of the development and construction on Bolivar Point was done by the federal government to aid navigation and support the important Port of Galveston. A lighthouse was built at the southwestern tip of Point Bolivar in 1852, to assist mariners entering Galveston Bay. The lighthouse was used in conjunction with a light boat that was placed just offshore of Point Bolivar. At the outset of the American Civil War, Confederate troops destroyed the lighthouse to make it more difficult for Union forces to navigate Bolivar Roads. Seven years after the close of the Civil War a second lighthouse was built at Point Bolivar (Figure 2). This new brick lighthouse was built on a robust nine-foot concrete foundation. Additionally, the 
entire 117 foot structure was sheathed with cast-iron plates that were riveted together. This construction method proved successful, as the lighthouse was one of the few structures to survive the devastating hurricanes of 1900 and 1915, as well as an accidental shelling from Fort San Jacinto in 1917. The 52,000-candlepower lighthouse was eventually retired in 1933, when it was replaced by the South Jetty Light (Daniels 2012).

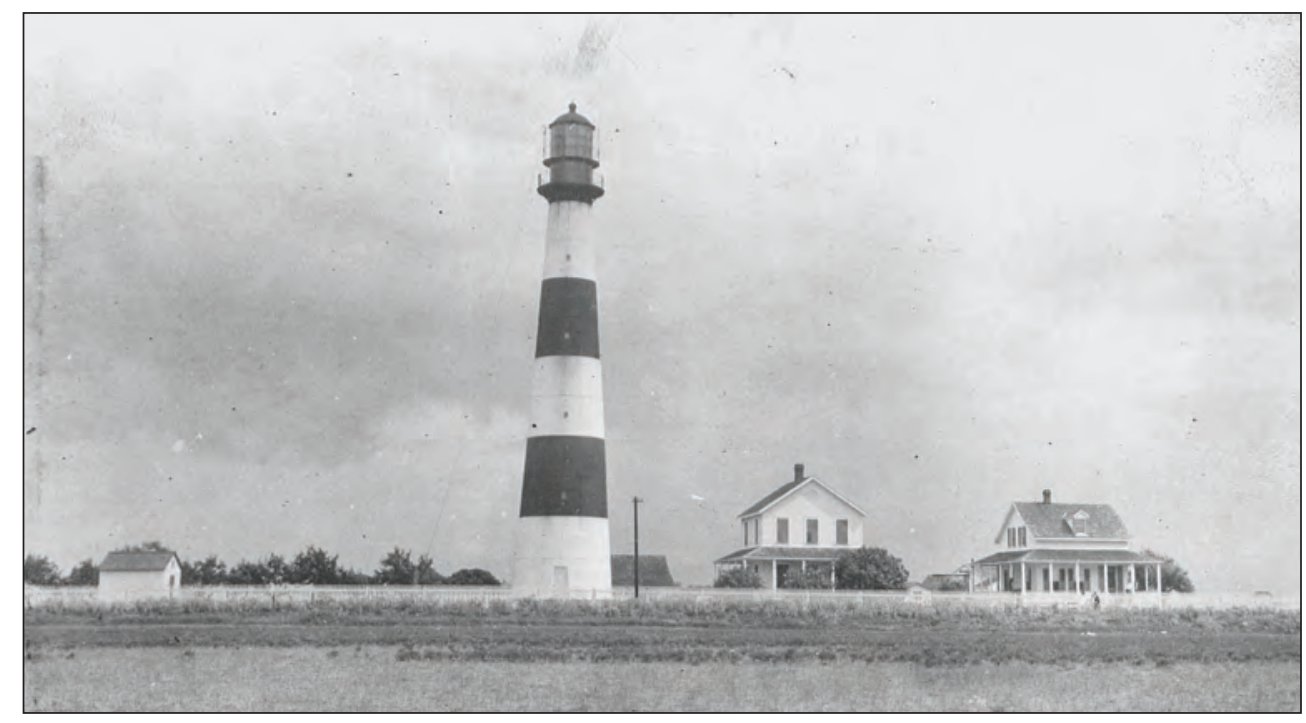

Figure 2. Second Point Bolivar lighthouse (source: http://www. uscg.mil/lantarea/ExternalAffairs/stormstories.asp).

In an effort to control sedimentation and deepen the channel between Fort Point and Pelican Spit, Captain C. W. Howell installed a more permanent breakwater that would run northeast along Fort Point towards the Bolivar channel and then turn seaward. A second parallel jetty was constructed along Bolivar Point. Due to a lack of known stone quarries in Texas, Howell proposed using man-made gabions to build the jetties. These gabion jetties were the initial attempt at channel deepening and sedimentation control. Successive efforts would eventually establish the current north and south jetties.

Gabions are cylindrical structures made of woven wicker that are covered with hydraulic cement. The Point Bolivar gabions measured $6 \mathrm{ft}$ tall and $6 \mathrm{ft}$ in diameter (Figure 3). Once the cement had hardened,

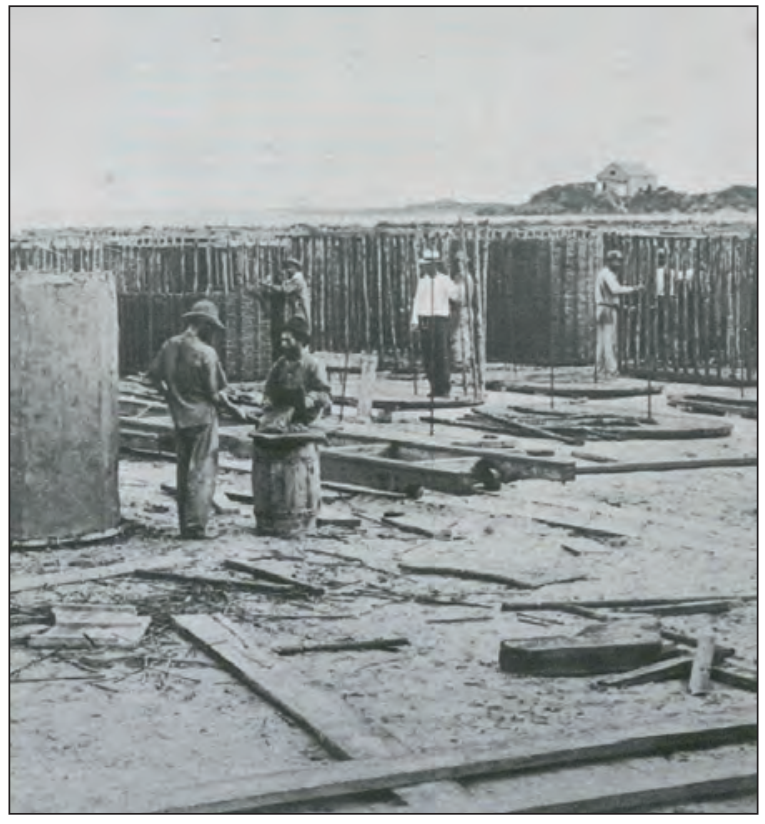

Figure 3. Gabion construction at Point Bolivar (source Alperin 1977). 
the cylinders were positioned (two rows for each jetty) and filled with sand and fastened together with copper wire (Alperin 1935:27). Construction and deployment of the gabions were delayed by weather, unavailable material, work suspensions, and other unanticipated obstacles. It took nearly seven years to complete, and in 1879 , it was determined that the Port Bolivar jetty produced no significant results. It was determined that in order to effect changes to the channel and the outer bar, the jetty would need to be extended farther into the Gulf of Mexico (Alperin 1935:33).

Land for the second Fort Travis was purchased in 1898 and was located on the southern end of Point Bolivar. It was built to supplement coastal artillery located across the pass in Galveston. Construction of the four batteries that would become the fort began in 1898 and lasted until 1943. Before the site was eventually demolished, the fort was comprised of twenty-seven buildings, all of which were occupied by troops in World War I and World War II.

All of the federally funded projects on Bolivar Peninsula brought families to the peninsula; many stayed and eventually established the community of Port Bolivar. The fertile soil allowed residents to grow crops like watermelon, wheat, and other fruit that could be sold in Galveston. Initially, these goods were transported from Port Bolivar to Galveston by small sailing vessels, but later would be replaced with ferries and barges. Crops and goods were also transported off the peninsula via the Gulf and Interstate Railway railroad. The rail line was severely damaged in the hurricanes of 1900 and 1915, which greatly affected commerce and settlement on the peninsula (Daniels 2012).

The State Highway Department took over operation of ferry service in 1933 between Bolivar Point and Galveston, allowing free public service across Bolivar Roads. Despite the great advantage of free ferry service, Bolivar Peninsula never saw a significant influx of people to inhabit the land. By the 1990s, the permanent population was approximately 4,000 people. Many of the homes are used by vacationers and weekend visitors who enjoy outdoor recreational activities.

\subsection{Previously Identified ShipWrecks AND Historic Cartographic Features}

The Team reviewed several databases of reported shipwrecks to help identify potential submerged cultural resources within or adjacent to the project area. These sources include the following:

- Bureau of Ocean Energy Management (BOEM) Resource Information Database

- Global Maritime Wrecks Database (GMWD)

- National Oceanic and Atmospheric Administration's (NOAA) Automated Wreck and Obstruction Information System (AWOIS)

- NOAA nautical charts

- Texas Archeological Sites Atlas 
- SEARCH shipwreck database (assembled from various sources)

- US Navy shipwreck database

Appendix A, Figure 1 and Table 1 include shipwrecks that have been reported within $1.0 \mathrm{~km}$ $(0.6 \mathrm{mi})$ of the project area. It is important to note that position accuracy for historic shipwrecks is tentative at best in most instances. Historic shipwrecks generally are plotted based upon contemporary records, maps, or oral histories. Many shipwreck databases provide a range of position accuracy or an accuracy reliability scale. Moreover, wrecking events oftentimes are unreported, especially those events that involve smaller, vernacular craft. It must be assumed, therefore, that Appendix A, Figure 1, and Table 1 do not constitute an exhaustive list of shipwrecks potentially within the buffer zone, nor can it be assumed that every shipwreck truly resides where it is depicted. The interpretation of the remote-sensing data for this project (presented below) identifies no potential submerged cultural resources within the project area; therefore, intensive archival or cartographic research to identify potential shipwrecks documented in additional sources was not conducted.

Closest to the study area is a mapped wreck of unknown origin, name, or age first charted in 1971 (USCGS Chart 518, Galveston Entrance), while farther to the southeast, historical records indicate that seven individual wrecks are located in the general area (Le Compte 1865, Pearl Rivers 1879, Tom Brown 1851, Beardstown 1875, Scandinavian 1895, and Climax 1831). With the exception of Climax, all of these vessels are listed State Archeological Landmarks (SALs) though their specific location could not be determined. The 1915-dated wreck of Little Dora, documented on the interior shoreline of Point Bolivar, is not listed as a SAL.

The Team did conduct additional cartographic research through NOAA's Office of Coast Survey Historical Map and Chart Collection to identify shoreline structures that might contribute to an increased potential for shipwrecks within the project area. The Team acquired historic charts between 1851 and 1953. An initial review of each chart was conducted to identify those that included structures potentially indicative of marine transport. These charts then were georeferenced in a GIS environment in order to depict the project location in relation to these historic structures. The historic charts were geo-referenced by registering geographic control points available in the chart (most often a graticule) with matching points in a modern, georeferenced navigation chart. Point registration resulted in a low total root mean square (RMS) error, which makes for an accurate geo-reference (Figure 4).

Prior to 1895 few structures existed on Bolivar Point. Structures consisted of a few buildings alongside the island's main road, presumably houses, and the locations of both lighthouses (the second lighthouse and some of these buildings can be seen in Figure 2. A railroad trestle jutting into the bay with a rail line extant between the trestle and the newly constructed north jetty are depicted on the southwest corner of the point between 1895 and 1899 (Figure 4, Chart 1). The rail line to the north jetty had been removed by 1908; a new rail line, the Gulf and Interstate Railway railroad, was constructed along the length of the island with its terminus at the trestle; and a 2.7-m-deep (9.0-ft) channel was dredged to the trestle (see Figure 4, Chart 2). Two vessel berths between three wharfs were constructed by 1910 and 1912. There is a gap in the collection between 1920 and 1933, at which time a second 3.7-m-deep (12-ft) channel 
terminating at a road on the southeast corner of the point had been dredged (see Figure 4, Chart 3). The channel terminates at a "Government Reservation" where it is labeled "Auto Ferry" on a 1936 chart. The channel is identified as the "Bolivar Ferry Channel" by 1937. The railroad wharfs are labeled "R.R. Ferry" on the 1936 chart. By 1944 a change in the location of automobile traffic across Bolivar Roads was underway. The rail line had been removed; a third channel had been dredged off the original "R.R. Ferry" channel, which terminates at a new road; and the "Auto Ferry" channel is no longer labeled, nor are there channel markers extant that depict its margin. The 1951 chart depicts a new ferry slip, labeled "Ferry," on the southwest corner of the point, which is labeled "Highway Ferry Channel" by 1953 (see Figure 4, Chart 4). The original "Auto Ferry" is labeled "Pier in Ruins" on the 1953 chart. From this point onward, automobile traffic crossed Bolivar Roads to land at this new ferry location.

\subsection{Previous InVestigations}

The Team reviewed the Marine Surveys layer of the THC's access-restricted ArcGIS Shipwreck Database to identify any previous marine surveys that have occurred within or adjacent to the project area. Ten previous maritime archeological investigations have been identified within $1.0 \mathrm{~km}(0.6 \mathrm{mi})$ of the project area, only one of which intersects the current project area (Figure 5). The western-most third of the proposed dredge expansion area has been previously surveyed through remote sensing by marine archeologists from PBS\&J in 2007 on behalf of TxDOT (TAC Permit 4467). Among the 47 magnetic anomalies identified that were recommended for avoidance or further evaluation, this Galveston-Bolivar Causeway survey identified two significant magnetic anomalies (13TAC 28.2) recommended for avoidance (M44 and M45). The avoidance zone boundaries recommended for these significant anomalies are located adjacent to or within the current survey corridor (see Appendix A). These significant anomalies are located in non-expansion portions of the APE. A 2004 marine remote sensing and hydro-probing survey by archeologists from Coastal Environments and PBS\&J for TxDOT's proposed third Bolivar Ferry Landing was conducted immediately to the west of the current dredge location and in the vicinity of the proposed expansion footprint (TAC Permit 3346). One magnetic anomaly was identified during survey and subsequently hydro-probed and found to not likely be a shipwreck. THC, having instated a 40-meter-radius avoidance zone around the anomaly, removed the avoidance and recommended the project could proceed with no properties affected (letter Lain Ellis to Steve Hoyt 7/22/2004). PBS\&J conducted a remotesensing survey of three sand borrow areas in Galveston Bay for the Texas General Land Office at various times between 2008 and 2010 (TAC Permit 4750). The Anchorage Basin C survey area is directly southwest of the current project area. PBS\&J's survey recorded numerous magnetic anomalies and side-scan sonar contacts throughout the three survey areas and recommended 19 anomalies as potential submerged cultural resources. None of the 19 anomalies are located within the current project area. No additional surveys have been conducted that overlap or lie directly adjacent to the currently-proposed dredge expansion APE. 


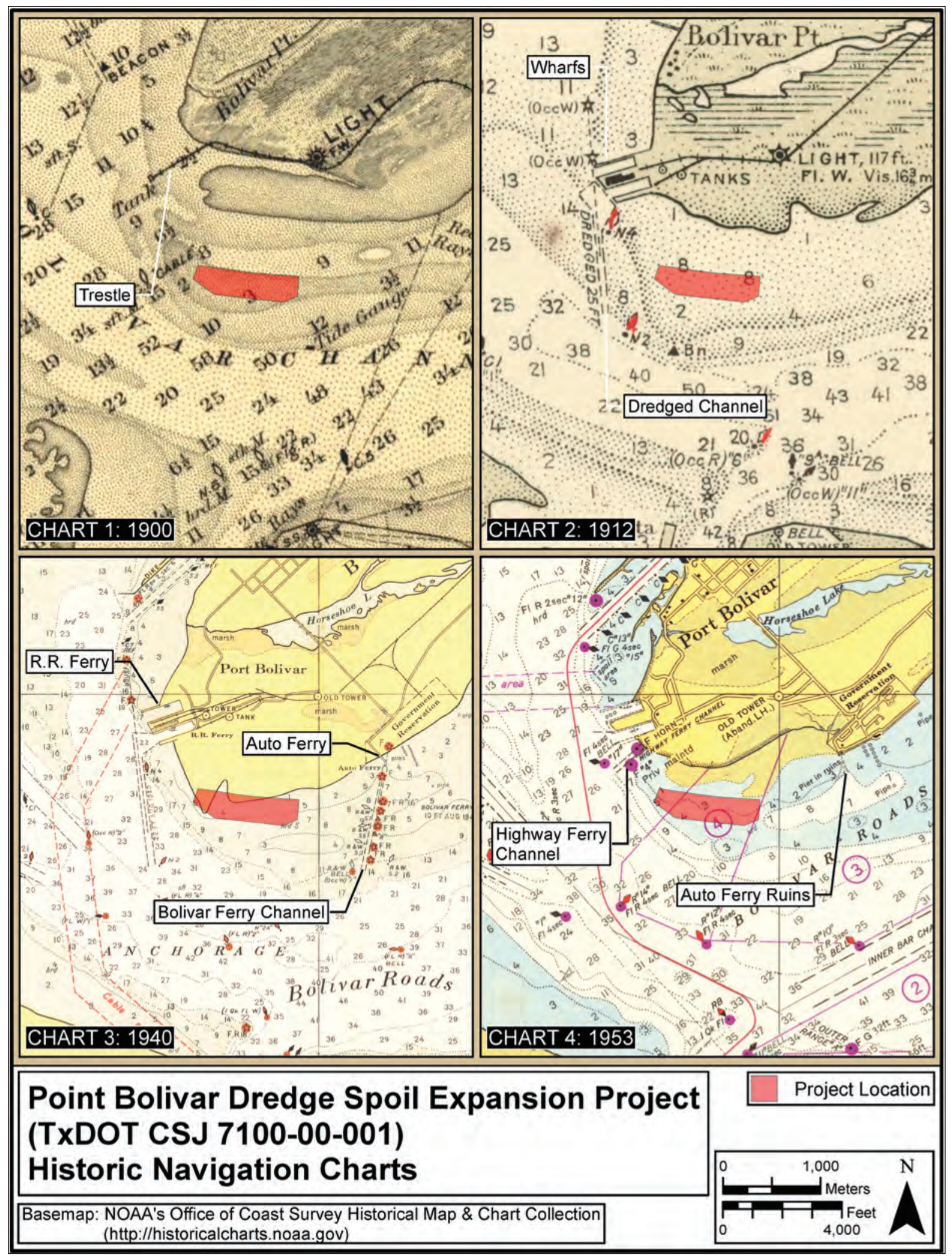

Figure 4. Historic Navigation Charts 


\section{Point Bolivar Dredge Spoil Expansion Project (TxDOT CSJ 7100-00-001) Archaeological Surveys within 1 Kilometer of Project Area}

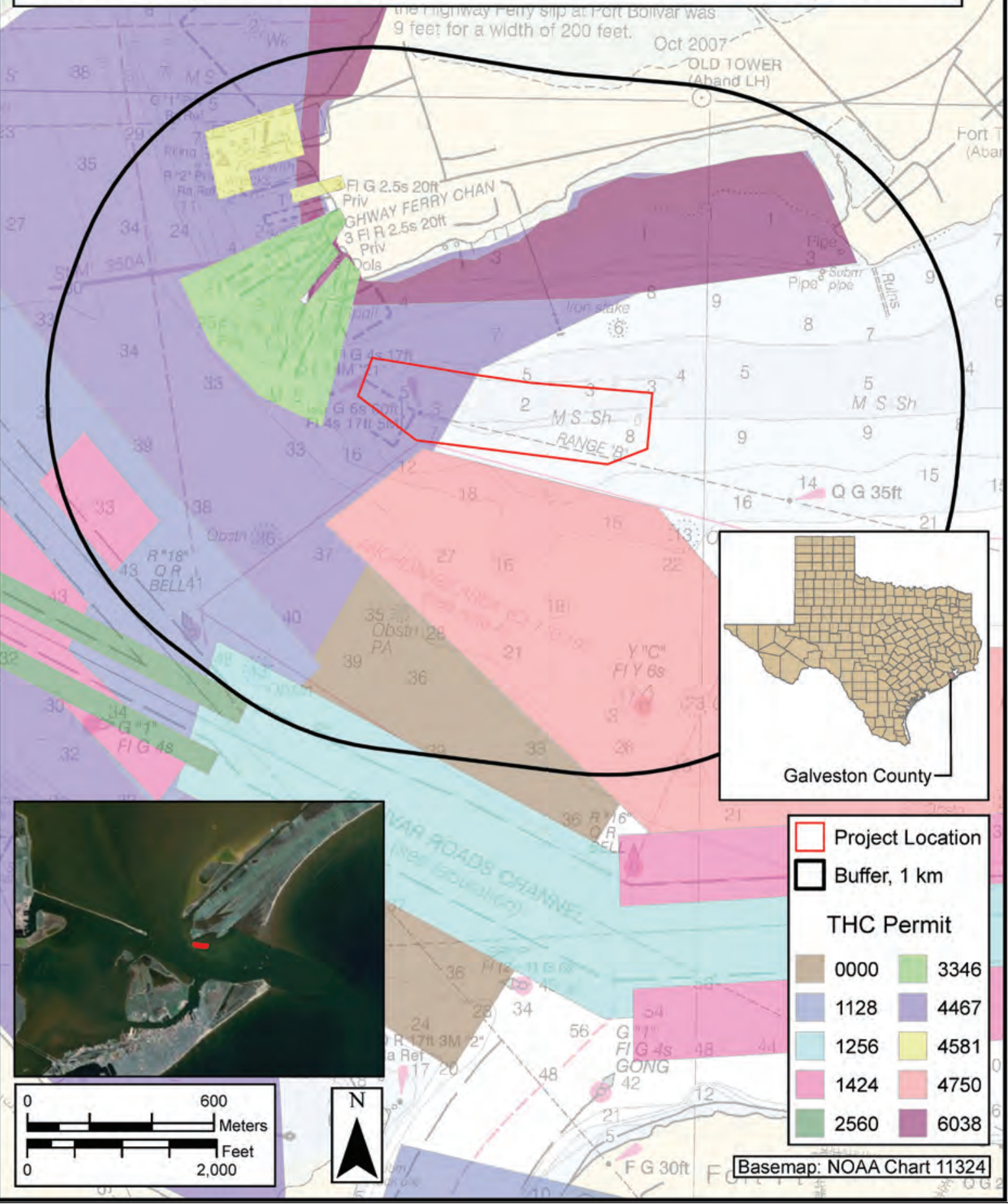

Figure 5. Map of previously conducted archeological surveys in the vicinity 


\section{Chapter 4 \\ Research Design and Field Methodology}

The Team developed a predictive model based upon environmental characteristics and maritime history of Galveston Bay presented in previous investigations (e.g., Enright 2009). The predictive model was utilized to help determine the potential for historic shipwrecks near the project area, as well as their likely design, composition, and age. The remote-sensing data collected for this project was then processed in a manner that facilitates identifying potential submerged cultural resources (described below). The predictive model provided a historical context for the interpretation of the processed remote-sensing data and a tool to help identify potential submerged cultural resources. The Team reviewed the Railroad Commission of Texas geographic information system (GIS) of oil and gas infrastructure and found no documented wells or pipelines within the project area that might correlate to remote-sensing data.

\subsection{Potential for Historic Shipwrecks}

Galveston Bay largely was ignored prior to the nineteenth century; maritime traffic at this time was limited to few exploration, trade, and pirating enterprises (Enright 2009:21). Maritime trade and transport in the bay proliferated beginning in the early nineteenth century, which increases the likelihood of historic shipwrecks in the project area dating to this era. The communities, towns, and ports established on the bay throughout the nineteenth and twentieth centuries served as impetus for waterborne commerce and recreation aboard watercraft ranging from small, vernacular sailing craft to larger steamboats and gas powered workboats. The potential exists, therefore, for the presence of historic shipwrecks of various types within the project area.

The documented abundance of small, wooden-hull sailing vessels between 1820 and 1900 likely will account for a significant portion of historic shipwrecks in Galveston Bay. This category of shipwreck will appear in the remote-sensing data as relatively smaller, lower amplitude magnetic anomalies with lower amplitude gradients. There likely would exist little to no side-scan sonar image associated with this vessel type due to the propensity of exposed wood to deteriorate rapidly in a marine environment, and a sufficient passage of time to bury any remaining structure. A somewhat less likely, but potential category of historic shipwrecks in Galveston Bay is the wooden-hull steamboat. An anomaly associated with this vessel type would be relatively larger and higher in amplitude, with a corresponding amplitude gradient. A side-scan sonar target could exist for this vessel type and might consist of exposed individual or complex concentrations of iron steam engine components. This image might not be identifiable as a shipwreck due to a lack of surviving, exposed hull. The 20th century workboat is another category of shipwreck to expect in Galveston Bay. This category likely constitutes a significant percentage of shipwrecks in the bay. Many of these shipwrecks will be located in close proximity to navigation channels. The magnetic anomaly of an iron or steel vessel propelled with a steam or gasoline engine would be strikingly large and intense, with a 
much higher amplitude gradient than other historic vessels. The hull and machinery are more likely to have survived in some form above the sediment level; therefore, there exists a high potential of recording a recognizable side-scan sonar image (Enright 2009:21-22).

Environmental conditions, as described in Chapter 2, indicate that shipwrecks, if found in the vicinity, would likely be relatively well preserved. The rapid covering by silt would preserve the hull materials and likely preserve their overall integrity as defined in 36 CFR 60.4.

\subsection{Survey Methodology}

During the course of survey, archeologists had access to all portions of the study area (Figure 6). Though the dredge spoil pile is located in the vicinity of the Bolivar Ferry landing and the busy Bolivar Roads corridor (including a chance sighting of a Space Shuttle replica being towed on a barge; Figure 7), ship traffic was generally low within the actual APE. A large navigation range light was noted standing within the southern half of the survey area while two crab pot buoys were easily avoided

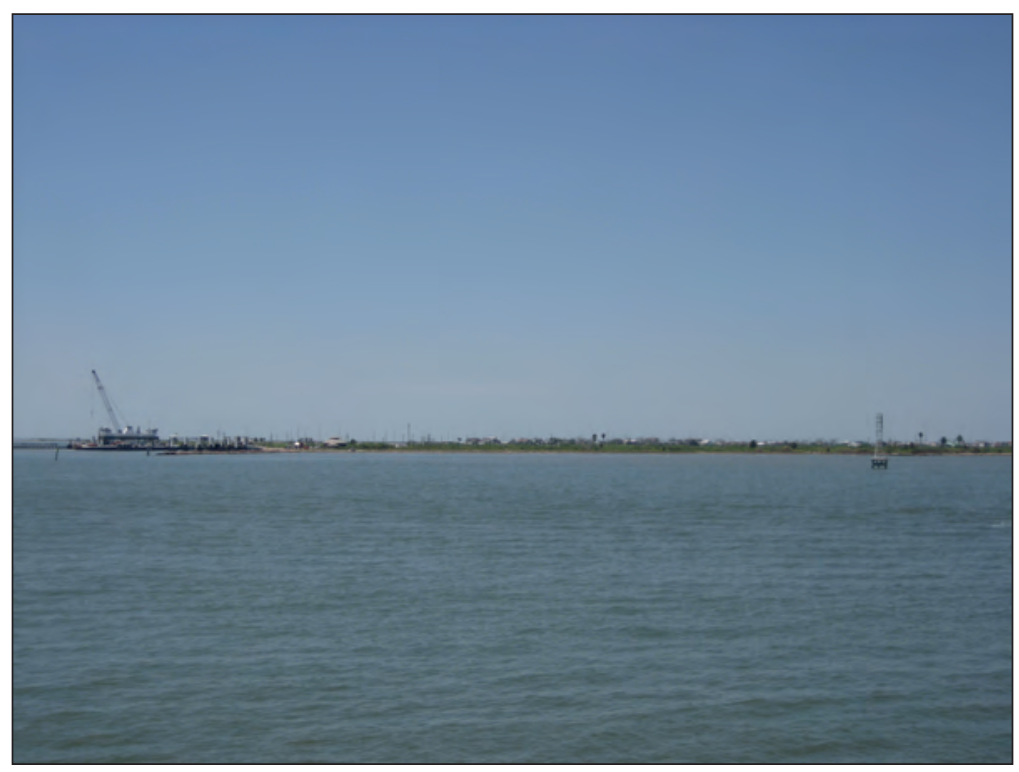

Figure 6. General photo of the project area (facing northwest). Note sighting marker in right-center of photograph. during survey. Work was conducted from a 6.7-m (22-

ft) fiberglass survey vessel (Figure 8). Environmental conditions at the beginning of the survey consisted of cloudy skies, light wind (less than 10 knots), and light to moderate water chop (less than $0.6 \mathrm{~m}[2.0 \mathrm{ft}]$ wave height). Squall conditions in the afternoon consisting of heavy rain, cloud to ground lightning, and low visibility interrupted the survey in the early afternoon (see Figure 9). These conditions lasted nearly 2 hours, after which the survey resumed. Environmental conditions for the remainder of the survey consisted of moderate wind (10-15 knots) and moderate water chop (0.6-0.9 m [2.0-3.0 ft] wave height). Water depths in the project area ranged from 0.9 to $4.3 \mathrm{~m} \mathrm{(3.0} \mathrm{to} 14 \mathrm{ft})$, which allowed the magnetometer towfish to be towed on the water's surface and the side-scan sonar towfish $0.9 \mathrm{~m}(3.0 \mathrm{ft})$ beneath the surface. This enabled sufficient survey altitude for both instruments. The survey design included 12 parallel survey lines spaced $20 \mathrm{~m}$ (66 ft) apart, for a total of 10 line-kilometers $(6.2$ line-mi) covering 67 acres (Figure 9). All work conformed to relevant guidance in the ACT as defined in 13 TAC 28.6. 
Figure 7. Photo of a Space Shuttle replica being towed into Galveston Bay during the brief, heavy thunderstorm that temporarily interrupted survey.

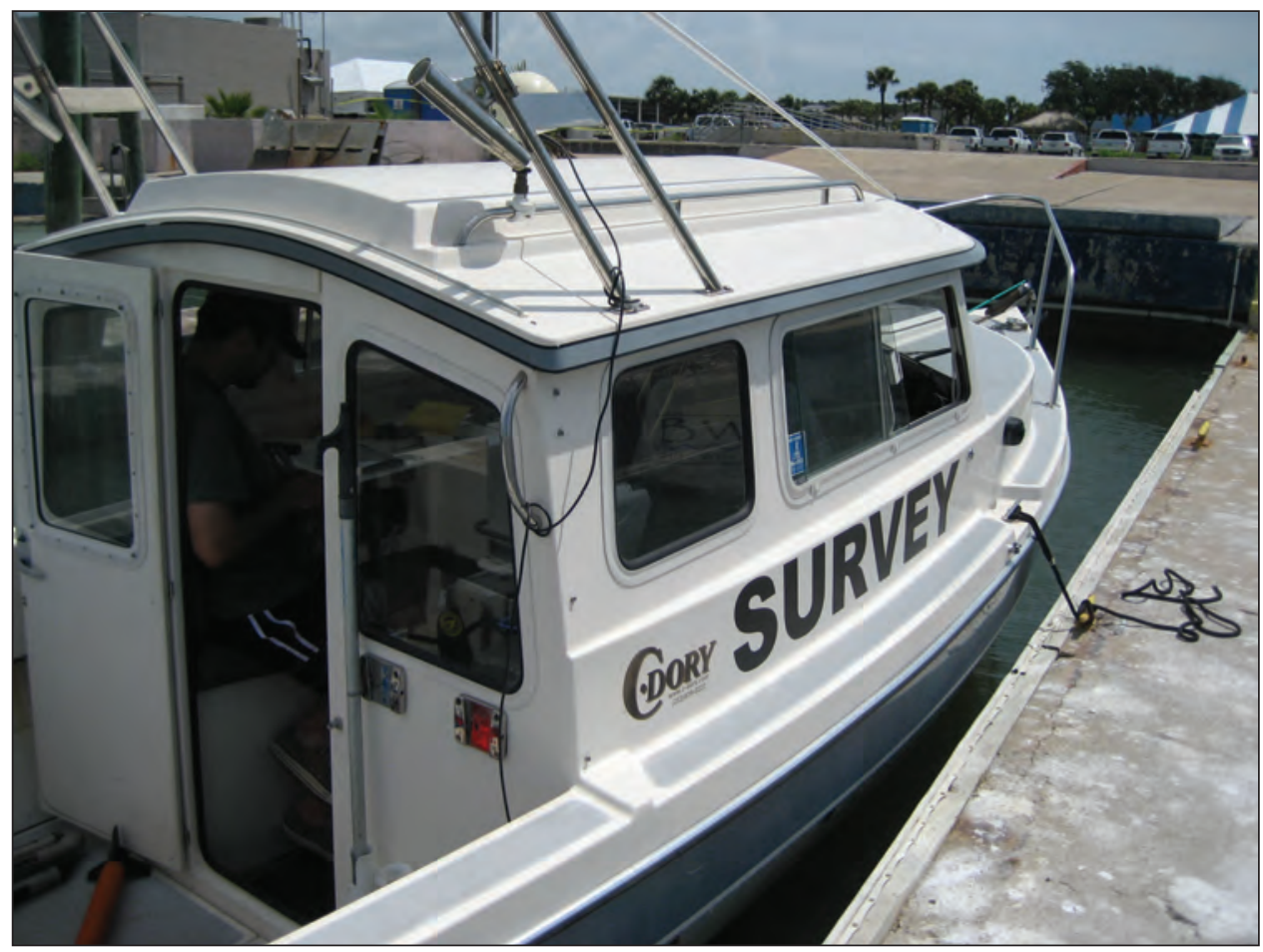

Figure 8. Survey vessel at port setting up for investigations. 


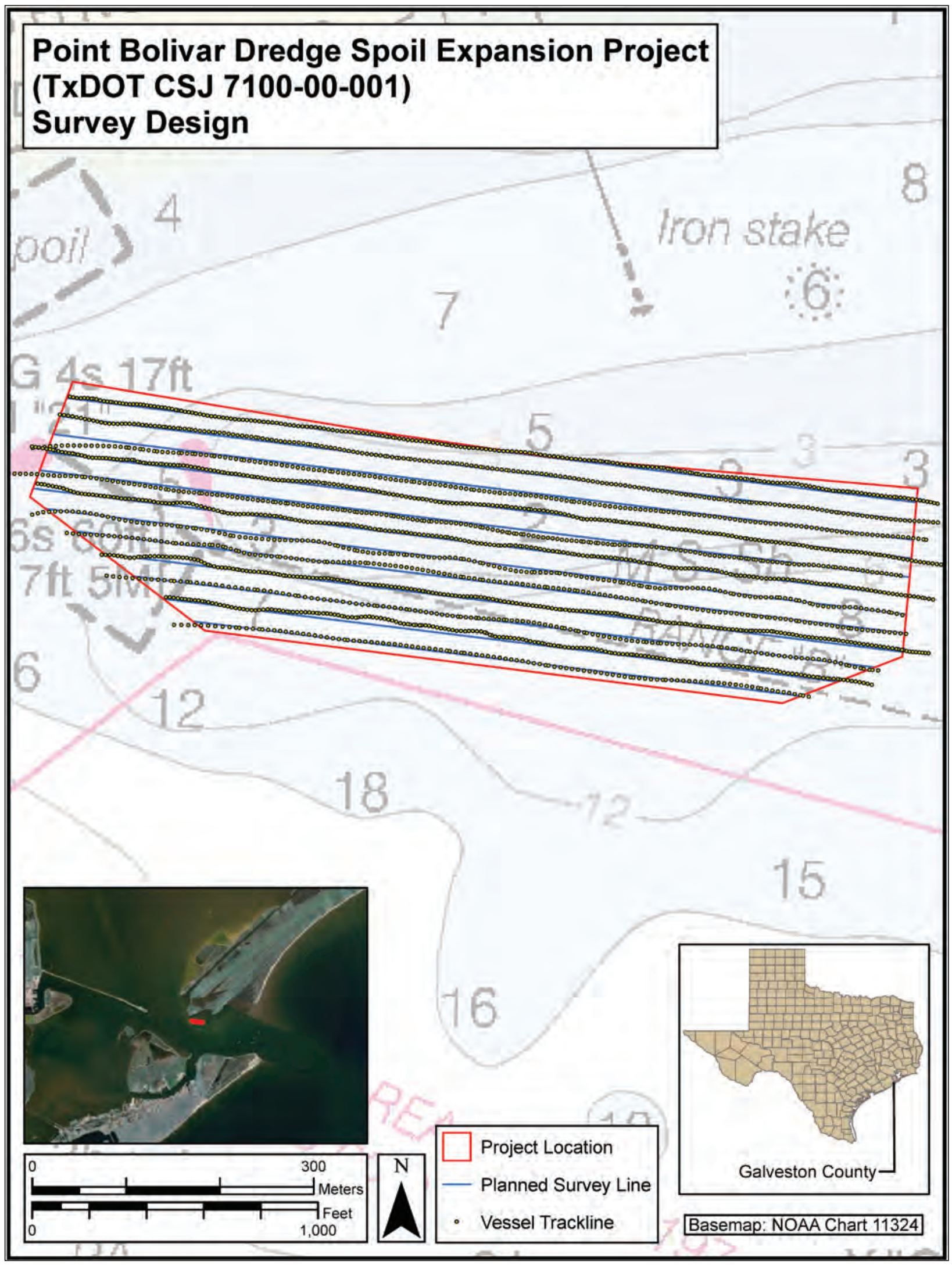

Figure 9. Survey transects followed to conduct marine investigations. 
Instrumentation for the survey consisted of a Trimble DSM 232 differentially corrected global positioning system receiver (DGPS); a Marine Magnetics Explorer Overhauser total-field magnetometer; an L-3 Klein System 3000 dual-frequency $(100 / 500 \mathrm{kHz})$ digital side-scan sonar; and a Garmin 160C echosounder $(200 \mathrm{kHz})$. Vessel guidance was accomplished utilizing HYPACK, Inc. hydrographic survey software. For the most part, vessel guidance proceeded uninterrupted at a speed that averaged 4.5 knots. HYPACK maintained equipment positioning throughout the survey, by means of layback calculations, and logged real-time positional, magnetic, and bathymetric data (Appendix C). The side-scan sonar operated at a frequency of $500 \mathrm{kHz}$ and a range of $25 \mathrm{~m}(82 \mathrm{ft})$ (i.e., total swath width $=50 \mathrm{~m}[164 \mathrm{ft}])$. The combination of survey line spacing and range allowed for 100 percent imagery coverage of the project area, including the nadir region beneath the towfish path. The DGPS was interfaced with the sonar topside acquisition computer, which embedded positional data into the imagery and allowed geo-rectification of the sonar record. Sonar imagery was collected at a constant stream while positional, magnetic, and bathymetric data were collected at a rate of $1 \mathrm{~Hz}$. Data from all instruments were collected over all 10 survey line-km (6.2 line-mi) without interruption. The survey was conducted in the Universal Transverse Mercator (UTM) coordinate system (Zone $15 \mathrm{~N}$ ) based on the North American Datum (NAD) 83 datum.

\subsection{Remote-Sensing Data Processing and INTERPRETATION METHODOLOGY}

\subsubsection{Magnetometer}

The raw magnetic data ( $\mathrm{x}$, y positional coordinates $+\mathrm{z}$ magnetic values) were processed into a contour map, which allows the best representation of three-dimensional data on a twodimensional plane and facilitates interpretation of the interaction of a magnetic source with the earth's magnetic field. The process involved with creating this contour map consists of removing the diurnal variation from the data, creating a regularly spaced grid of the irregularly spaced data points, and generating contours that are visually concise and accurately represent anomalies in the earth's magnetic field.

The earth's background magnetic value at any particular geographic location fluctuates slightly from day to day and throughout each day. This variation is evident in the raw magnetometer data ( $\mathrm{z}$ value) and results in a cluttered map when contoured. In order to overcome this, SEARCH filtered the raw magnetometer data through a mathematical algorithm. The algorithm defines each raw $z$ value as either higher than the magnetic background (positive) or lower than the magnetic background (negative). The algorithm replaces the raw $\mathrm{z}$ value with this positive or negative number, which is relative to the magnetic background at the particular date, time, and geographic location it was recorded. The diurnal variation is easily identified and removed from the relative $\mathrm{z}$ values, which facilitates contouring and provides a "clean" contour map.

The $\mathrm{x}, \mathrm{y}$, and relative $\mathrm{z}$ data were imported into Golden Software, Inc.'s Surfer contouring and 3-D surface mapping software. SEARCH instructed Surfer to grid the processed magnetic data based on data collection methodology and magnetic theory as it applies to the correlation 
between source amplitude and its distance from the magnetometer sensor. The inline distance between raw data points, based on the rate of collection $(1 \mathrm{~Hz})$ and the average survey vessel speed during data collection (4.5 knots), equates to approximately $2.3 \mathrm{~m}$ (7.5 ft). Data were collected along parallel survey lines spaced approximately $20 \mathrm{~m}(66 \mathrm{ft})$ apart. Based on these parameters, SEARCH's Surfer gridline geometry was set at $2.3 \mathrm{~m}(7.5 \mathrm{ft})$ between nodes, with

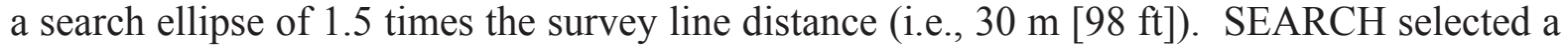
gridding interpolation method following the magnetic theory that magnetic amplitude decreases inversely proportional to the cube of the distance between the source and the magnetometer sensor (Breiner 1999). The resulting magnetic data grid consists of regularly spaced data nodes interpolated from the irregularly spaced magnetometer data. SEARCH next contoured the filtered relative magnetometer data using the interpolated magnetic data grid. Contour interval was set at 5 gammas $(\gamma)$ with $100-\gamma$ index contours. The contours illustrated in Appendix A, Figure 2 present 5- $\gamma$ positive contours as orange and negative contours as light blue. Index contours are illustrated in red (positive) and dark blue (negative).

Previous research concerning magnetic theory as it applies to archeological resources and remote-sensing survey (e.g., Breiner 1999; Enright et al. 2003, 2006; Garrison et al. 1989; Gearhart 2004, 2011; VonFrese 1986) assisted SEARCH's interpretation of the processed magnetic data and helped to identify the presence or absence of potential shipwreck anomalies. Research has demonstrated that the complex distributions of the many ferromagnetic components of a typical eighteenth-twentieth century vessel tend to cancel one another in the shipwreck's contoured magnetic signature, and present a relatively simple pattern as a whole. The composite magnetic signature of a complex source such as a shipwreck consists of the permanent magnetism of each individual ferromagnetic component plus the relatively weaker induced magnetism caused by the earth's magnetic field. Even though the permanent magnetism of the individual components alone would dominate the weaker earth-induced magnetism, a complex concentration of numerous magnetic anomalies overlapping one another tends to minimize or negate the permanent magnetism of individual ferromagnetic objects, leaving a composite anomaly dominated by the earth-induced signature. As such, a shipwreck anomaly tends to exhibit a general dipolar pattern (i.e., a positive lobe and a negative lobe) where the polar axis is dominated by the earth-induced portion of the composite and therefore aligns itself with the earth's magnetic field, regardless of site orientation. As such, the majority of negative contours are oriented in the northern hemisphere of a shipwreck anomaly, while the majority of positive contours are situated to the south. The polar axis of the principal dipole (the magnetic vector from positive peak to negative peak) is oriented toward magnetic north, within \pm 26 degrees.

Site formation processes and decreased distance between sensor and source will alter this arrangement somewhat and induce a more complex anomaly. Surveys that decrease the sensorto-shipwreck distance (e.g., shallow-water survey) will produce a complex, multi-component anomaly comprised of multiple monopoles and dipoles within the induced anomaly pattern. This occurrence is exacerbated with shipwrecks consisting of copious amounts of cast iron or large ferrous construction features or machinery (e.g., an iron-hull steamship). Gearhart (2011:104) states that when magnetic survey occurs "in close proximity to a shipwreck, localized amplitude peaks associated with large individual ferromagnetic components may 
contrast with the surrounding induced anomaly pattern of the shipwreck as a whole." However, the anomaly will still exhibit the broader, underlying induced pattern described above.

Site formation processes also can induce complexity outside of the principal dipole. For example, a large iron feature, such as a boiler, that has been deposited away from the main shipwreck site can produce a separate magnetic signature that adds complexity to the characteristics of the shipwreck anomaly as a whole. Or, a site formation process that has included radical seabed movement, or scrambling devices, that result in what Muckelroy (1978:196) terms a "discontinuous site," can alter anomaly patterns. Scrambling devices that can produce a discontinuous site include strong tidal currents and extreme wave action, occurrences exacerbated in shallow water, as well as salvage and explosion. Such a site can produce widely distributed ship components and anomalies with large areal extents. Depending on the level of distribution, a principal dipolar anomaly may or may not exist for a discontinuous site.

Polar alignment and complexity of the anomaly are perhaps the most important characteristics to consider when interpreting magnetic data for potential shipwrecks. Other characteristics that help distinguish shipwreck magnetic signatures from other signatures (e.g., capped petroleum wells and debris) include the peak-to-peak amplitude gradient, the negative-topositive amplitude ratio, and continuity. Continuity helps to differentiate a shipwreck, which is a complex distribution of objects, from debris fields, which also are complex distributions of objects. Shipwrecks possess more continuity among their central dipoles than do debris fields. Shipwrecks tend to possess peak-to-peak amplitude gradients higher than petroleum wells and a more equal amplitude distribution between their poles. Known examples of shipwreck magnetic signatures from Gearhart (2004) possess amplitude ratios less than 1:4. Examples of wood-hull sailing vessels possess gradients, between their poles, from 15 to $30 \mathrm{\gamma} / \mathrm{m}$, and examples of iron/steel and/or steam/gasoline-powered vessels possess gradients above

$100 \mathrm{\gamma} / \mathrm{m}$ (Gearhart 2004). Finally, Enright et al. (2006:147) has suggested that a 20-m (66-ft) survey line spacing would result in "...detection of a near-100-percent sample of small woodenhulled sailing vessel anomalies on two adjacent lines." The present survey line spacing of 20 $\mathrm{m}(66 \mathrm{ft})$ allows for a general statement regarding potential shipwreck anomalies: it can be expected that the majority of nineteenth and twentieth century shipwrecks within Galveston Bay will exhibit anomalies that span multiple survey lines.

\subsubsection{Side-Scan Sonar}

The Team reviewed each line of raw side-scan sonar imagery from the survey to locate manmade features and potential submerged cultural resources protruding above the seafloor. Each object was assigned a contact number, and descriptive information was collected and tabulated (e.g., length, width, DGPS position, possible identification, etc., Appendix D). SEARCH also generated a mosaic image of the project area comprising all raw sonar imagery (Appendix A, Figure 3). The ability to mosaic the imagery was made possible with embedded positional data from the DGPS data string utilizing SonarWiz.Map V5.05.0006 sonar processing software. High-frequency imagery files $(500 \mathrm{kHz})$ were imported into the software utilizing settings adjusted for the Klein System 3000 acquisition methods. Following importation of the raw 
imagery, bottom tracking was performed to identify the first acoustic return, which determines the altitude of the towfish above the seafloor, creates a slant-range corrected record, and removes the water column from the nadir region. Returns from the overlapping files were averaged. Thus, if a contact contrasts well on one track line but not on an adjacent line, averaged returns from both lines ensure significant contrast for contact detection. Gain, color, and contrast settings were adjusted for each file in order to produce an optimal and even image across the entire mosaic. The mosaic was exported as a geo-rectified image with a resolution of $0.05 \mathrm{~m} /$ pixel ( $0.16 \mathrm{ft} /$ pixel) and imported into ArcGIS 10 so that it could be layered with other project data (e.g., magnetic contour map, project boundary, etc.) and facilitate archeological analysis.

\subsubsection{Bathymetry}

Bathymetry was collected solely for future archeological planning purposes. As such, no processing of these data occurred. 


\section{Chapter 5 \\ Results of Field Investigations}

In reviewing the remote sensing data generated through field investigations, the archeological APE within the proposed dredge expansion area is considered likely devoid of historic-age shipwrecks/Historic Properties/SALs. Magnetometer contours (Appendix A, Figure 2) reveal a surface that is generally free of large features but dotted with isolated modern debris. With the exception of three targets (see below) none of the remaining anomalies are noteworthy as they do not exhibit negative-north oriented dipoles, amplitude gradients or ratios consistent with a shipwreck, and lack expected continuity across more than one survey line (as would be expected with a shipwreck). Sonar mosaics complement the magnetic data, revealing an underwater surface that is devoid of shipwrecks (Appendix A, Figure 3). Of note from a noncultural resource perspective, side-scan sonar imagery did reveal a portion of a large oyster reef extending into the archeological APE that may be a consideration in environmental permitting for the project. This reef is depicted in Appendix A, Figure 3.

\subsection{Noteworthy Targets/AnOMalies}

Anomaly M1/Contact S06 is located near the southern portion of the archeological APE. Through comparison with other, similar features standing in the vicinity, and its location in line with Range "B" on navigation Charts (Chart 11324), the Team can confirm that this anomaly is not a historic age shipwreck but is rather a modern, downed range light (navigation aid; Figures 10 and 11). Anomaly M2 was identified on two separate survey lines as a low amplitude $(-40 / 25 \gamma)$, dipolar feature with a gradient of $2.8 \gamma / \mathrm{m}$. A corresponding sonar contact (S01) was imaged, which consists of a 3 x 3-ft $(0.9$ x 0.9-m) boxlike element. While the

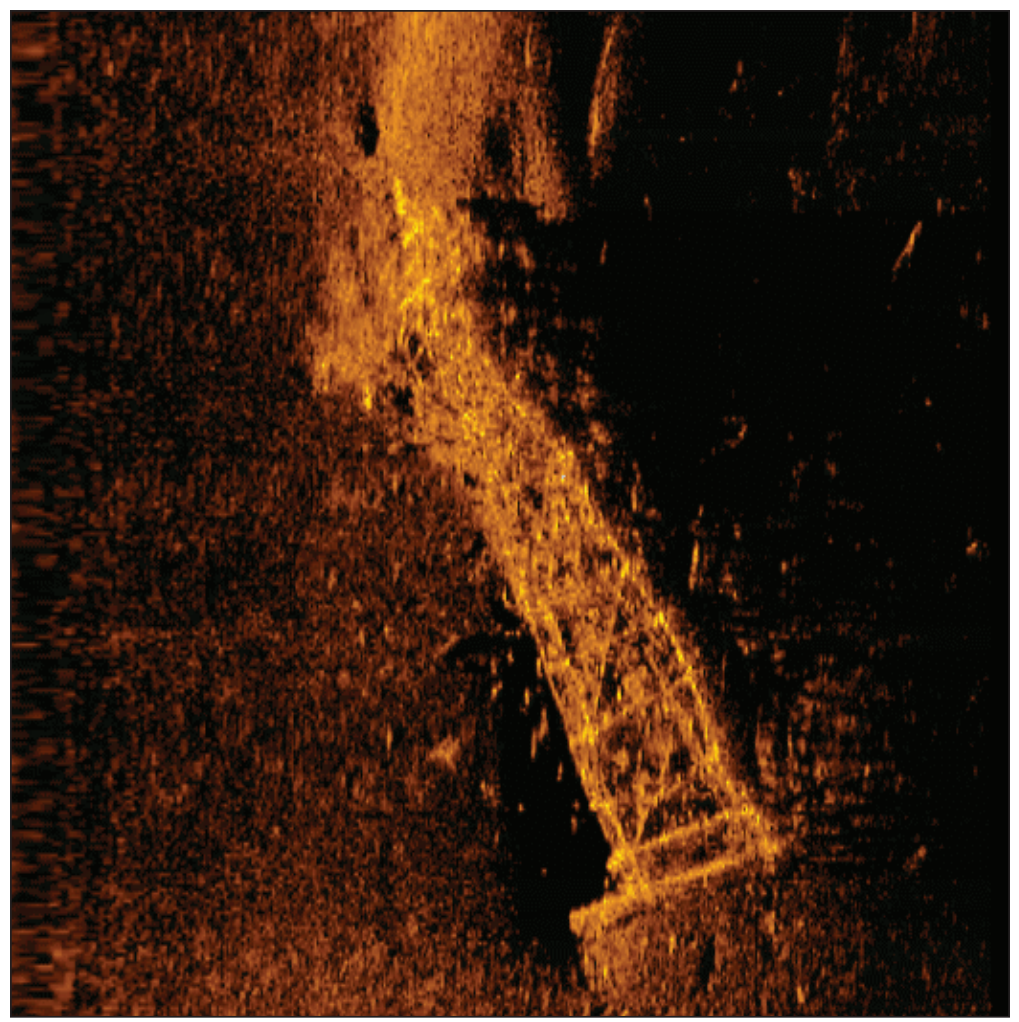

Figure 10. Side scan sonar detail of M1/S06. 
feature's magnetic orientation and amplitude ratio resemble known shipwreck signatures, its low amplitude and gradient, and corresponding sonar contact suggest that the source is likely modern debris. Finally, anomaly M44, documented within the existing dredge spoil pile area during PBS\&J's 2007 survey (at the western terminus of the archeological APE) was observed at the same location in the current investigation and is therefore considered intact (see Appendices A, C and D).

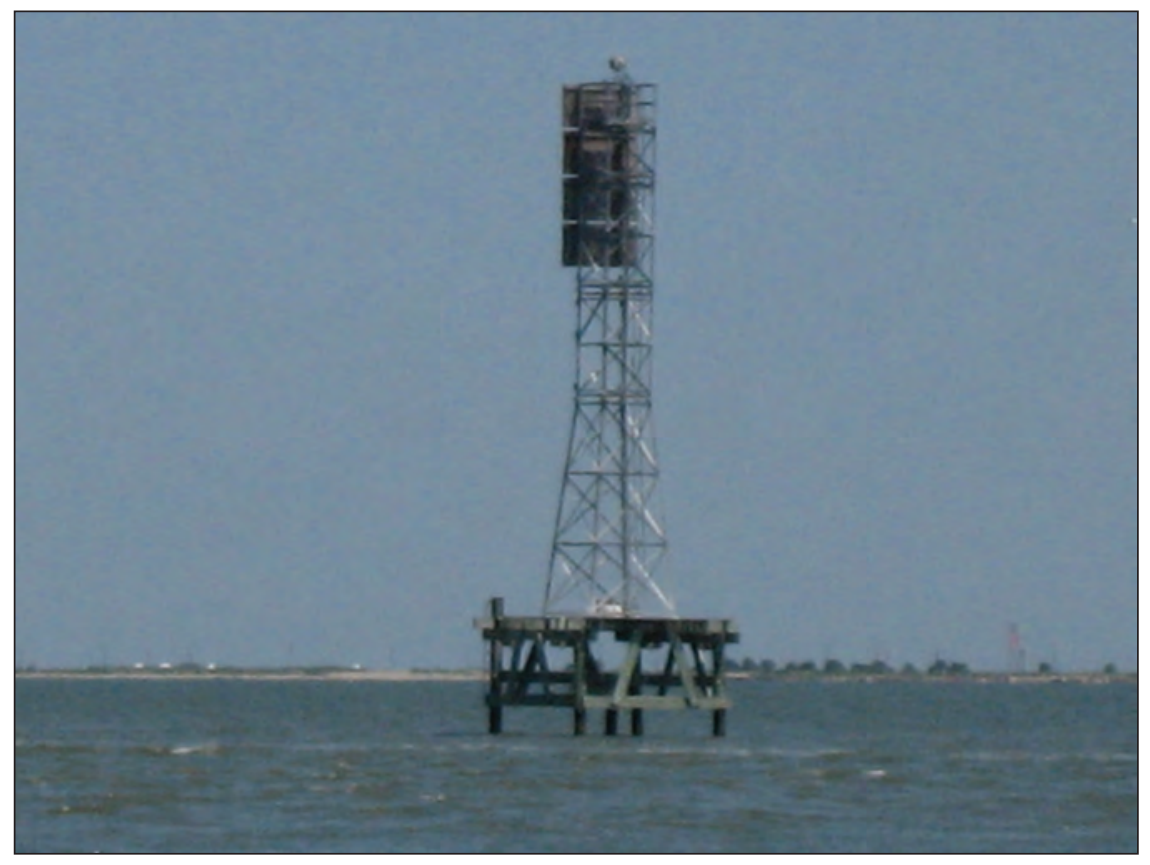

Figure 11. Photo of standing, modern range marker located in vicinity of M1/S06. 


\section{Chapter 6 \\ Conclusions And Recommendations}

Archeologists from AmaTerra and SEARCH conducted marine archeological survey within the archeological Area of Potential Effects of the proposed expansion of the Bolivar Ferry dredge spoil area. All work was completed on behalf of the TxDOT-ENV for compliance with the NHPA of 1966 and the ACT on land owned by the State of Texas (Texas General Land Office). Survey was conducted under Antiquities Permit 6272. Archeologists surveyed approximately 67 acres of the proposed and existing dredge spoils deposition area including 16 acres of previous spoils area and 51 acres of proposed expansions. No potential archeological sites, features, or artifacts were newly-documented as a result of the field effort, although one previously-identified anomaly (M44) was relocated.

The marine remote-sensing survey included magnetometer, side-scan sonar, and bathymetric investigation along twelve, 20-meter-interval linear survey transects with access to 100 percent of the archeological APE. Magnetometer results identified a bottom that was primarily dotted with isolated pieces of debris that are likely modern with none exhibiting signatures that are typical of historic-age shipwrecks or artifact scatters. Side-scan sonar imagery revealed no contacts within the survey area that are typical of submerged archeological resources.

One large fallen navigation range light was identified within both the magnetometer and side scan sonar data near the southern APE boundary (M1/S06). A small box-like element (M2/ S01) was identified within the survey corridor that did bear a magnetic signature similar to that of a historic shipwreck, but it is visibly of modern origin. Neither of these finds is considered a historic-age resource and neither is recommended for avoidance or cultural resource consideration in project planning. Archeologists did encounter a similar magnetic signature of the previously-identified M44 within the existing dredge pile area at the same location. It is assumed that the feature is still extant and the previously-established avoidance zone is recommended to remain active for this phase of work with no dredge deposition recommended within its boundary.

Avoiding the M44 area, the Principal Investigator recommends that the proposed undertaking has minimal potential to impact significant marine archeological resources and work is recommended to proceed in accordance with 36 CFR 800, 36 CFR 60, and 13 TAC 26 with no further archeological work required. If project plans change, additional archeological resource coordination and/or field investigations may be recommended. In the unlikely event that archeological resources are encountered during construction all work in the vicinity should cease until such time as they can be assessed and coordinated by a qualified archeologist prior to resuming work in the vicinity.

Having recorded no sites, all field-generated materials will be permanently curated at AmaTerra's offices in Austin, Texas. This report is offered in partial fulfillment of TAC Permit 6272 . 


\section{REFERENCES}

Alperin, L. M.

1977 Custodians of the Coast: History of the United States Army Engineers at Galveston. Galveston District United States Army Corps of Engineers, Galveston, Texas.

Barker, E. C. (editor)

1924 "The Austin Papers." In Annual Report of the American Historical Association for the Year 1919, 2 vols., Government Printing Office, Washington, D.C.

Bernard, H. A., R. J. LeBlanc, and C. F. Major

1962 "Recent and Pleistocene Geology of Southeast Texas," in Geology of the Gulf Coast and Central Texas and Guidebook of Excursions, Houston Geological Society, 175-224.

Block, W. T.

1995 Cotton Bales, Keelboats, and Sternwheelers: A History of the Sabine River and Trinity River Cotton Trades, 1837-1900. Dogwood Press, Woodville, Texas.

Breiner, S.

1999 Applications Manual for Portable Magnetometers. Geometrics, San Jose, California.

Bricker, R. W.

1998 Wooden Ships from Texas: A World War I Saga. Texas A\&M University Press, College Station, Texas.

Clopper, J. C.

1828 “J. C. Clopper's Journal and Book of Memoranda for 1828. Province of Texas." In Quarterly of the Texas State Historical Association, 13(1910): 52.

Cotham, E. T., Jr.

1998 Battle on the Bay: The Civil War Struggle for Galveston. University of Texas Press, Austin, Texas.

Daniels, A. P.

2012 "Bolivar Lighthouse." Handbook of Texas Online (http:/www.tshaonline.org/handbook/online/ articles/ccb03), accessed July 03, 2012. Published by the Texas State Historical Association.

2012 “Bolivar Peninsula.” Handbook of Texas Online (http://www.tshaonline.org/handbook/online/ articles/rrb06), accessed July 03, 2012. Published by the Texas State Historical Association. 
Darst, M.

2012 "Fort Travis." Handbook of Texas Online (http://www.tshaonline.org/handbook/online/articles/ qcf23), accessed July 03, 2012. Published by the Texas State Historical Association.

Enright, J. M.

2009 Maritime Archaeological Data Review and Phase II Underwater Investigations for the Denbury Green Pipeline Project, Galveston Bay, Texas. Submitted to SWCA Environmental Consultants by BIO-WEST, Inc., Rosenburg, Texas.

Enright, J. M., J. Watts, and R. L. Gearhart

2003 Marine Remote-Sensing Survey and Diving Assessment for Historic Properties Investigations, Corpus Christi Ship Channel Improvements and La Quinta Ship Channel Extension, Corpus Christi Bay, Texas. Submitted to U.S. Army Corps of Engineers, Galveston District by PBS\&J, Austin, Texas.

Enright, J. M., R. Gearhart, D. Jones, and J. Enright

2006 Study to Conduct National Register of Historic Places Evaluations of Submerged Sites on the Gulf of Mexico Outer Continental Shelf. Submitted to Minerals Management Service by PBS\&J, Austin, Texas.

Fisher, W. L., J. H. McGowen, L. F. Brown, Jr., and C. G. Groat

1990 Environmental Geological Atlas of the Texas Coastal Zone-Galveston-Houston Area. Bureau of Economic Geology. The University of Texas at Austin.

Fisk, H. N

1944 Geological Investigation of the Alluvial Valley of the Lower Mississippi River. Submitted to the U.S. Army Corps of Engineers, Mississippi River Commission, Vicksburg, Mississippi.

Francaviglia, R. V.

1998 From Sail to Steam: Four Centuries of Texas Maritime History, 1500-1900. University of Texas Press, Austin, Texas.

Frazier, D. S.

1998 Cottonclads! The Battle of Galveston and the Defense of the Texas Coast. McWhiney Foundation Press, Abilene, Texas.

Garrison, E. G., C. P. Giammona, F. J. Kelly, A. R. Tripp, and G. A. Wolff

1989 Anomalies from Remote Sensing Surveys and Historic Shipwreck Patterns Within the Northern Gulf of Mexico, Reevaluation of Historic Shipwreck Studies of the Northern Gulf of Mexico. Volume II. Prepared for Minerals Management Service. 
Gearhart, R.

2004 Marine Remote Sensing: The Next Generation. Symposium presented at the Society for Historical Archaeology, 37th Conference on Historical and Underwater Archaeology. St. Louis, Missouri.

2011 Archaeological Interpretation of Marine Magnetic Data. In The Oxford Handbook of Maritime Archaeology, edited by Alexis Catsambis, Ben Ford, and Donny L. Hamilton, pp. 90-113. Oxford University Press, New York.

Leatherwood, A.

1996 “Galveston Bay,” In The New History of Texas, Vol. 3:53. The Texas State Historical Association, Austin.

McClean, M. D. (editor)

1975 Papers Concerning the Robertson Colony in Texas, Vol 2, 1823 through September 1826, Leftwich's Grant. Texas Christian University Press, Fort Worth, Texas.

Muir, A. F.

2008 "Harrisburg, Texas." In the Handbook of Texas Online, http://www.tshaonline.org/handbook/ online/articles/HH/hvh27.html (accessed August 13, 2008).

Pratt, W. W. (editor)

1954 Galveston Island or A Few Months off the Coast of Texas: The Journal of Francis Sheridan, 1839-1840. University of Texas Press, Austin, Texas.

Price, M. W.

1951 "Ships that Tested the Blockade of the Gulf Ports, 1861-1865." In American Neptune, vol. 11, pg. 262-290.

Rosendal, H. E.

1965 "Northers of the Gulf of Mexico and Central American Waters," Electronic Document. Available URL: http://members.aol.com/rosendalehe/northers.htm (last accessed August 1, 2008)

VonFrese, R. R. B.

1986 Magnetic Investigations of Structurally Complex Archaeological Sites. Paper presented at the Annual Meeting of the Geological Society of America. San Antonio, Texas.

Weddle, R. S.

1985 Spanish Sea: The Gulf of Mexico in North American Discovery, 1500-1685. Texas A\&M University Press, College Station, Texas.

1991 The French Thorn: Rival Explorers in the Spanish Sea, 1682-1762. Texas A\&M University Press, College Station, Texas. 
1995 Changing Tides: Twilight and Dawn in the Spanish Sea, 1763-1803. Texas A\&M University Press, College Station, Texas.

Wiggins, M. S.

2012 "Point Bolivar." Handbook of Texas Online (http://www.tshaonline.org/handbook/online/ articles/rrp05), accessed June 28, 2012. Published by the Texas State Historical Association.

2012 "Point Bolivar." Handbook of Texas Online (http://www.tshaonline.org/handbook/online/ articles/rrp05), accessed July 03, 2012. Published by the Texas State Historical Association.

Young, E. B.

1997 Galveston and the Great West. Texas A\&M University Press, College Station, Texas. 


\section{Appendix A \\ Sensitive Cultural Resource LOCATIONAL INFORMATION}


Table A-1: Recorded Shipwrecks within One Kilometer of Current Project Area

\begin{tabular}{|c|c|c|c|c|c|c|}
\hline ID & Source & Name & Year Lost & SAL & Vessel Type & $\begin{array}{l}\text { Positional } \\
\text { Accuracy }\end{array}$ \\
\hline 66 & THC & LE COMPTE & 1865 & Yes & sailing ship, merchant & 1 mile \\
\hline 630 & $\mathrm{THC}$ & PEARL RIVERS & 1879 & Yes & sailing ship, merchant & \\
\hline 635 & $\mathrm{THC}$ & TOM BROWN & 1851 & Yes & sail-steam, merchant & \\
\hline 984 & THC & BEARDSTOWN & 1875 & Yes & sail-steam, merchant & \\
\hline 1300 & $\mathrm{THC}$ & UNKNOWN & pre-1971 & No & unknown & \\
\hline 1318 & THC & UNKNOWN & pre-1971 & No & unknown & \\
\hline 1321 & THC & UNKNOWN & 1970 & No & unknown & \\
\hline 1483 & THC & SCANDANAVIAN & 1895 & Yes & sailing ship, merchant & \\
\hline 1963 & THC & CLIMAX & 1831 & No & sailing ship & \\
\hline 2033 & THC & LITTLE DORA & 1915 & No & Unknown & \\
\hline 869 & GMWD & UNKNOWN & 1934 & & & \\
\hline 873 & GMWD & UNKNOWN & 1934 & & & \\
\hline 874 & GMWD & UNKNOWN & 1934 & & & \\
\hline 255901 & GMWD & UNKNOWN & & & & \\
\hline 262876 & GMWD & UNKNOWN & & & & \\
\hline 264621 & GMWD & UNKNOWN & & & & \\
\hline 7770 & NOAA & UNKNOWN & & & & \\
\hline 7771 & NOAA & UNKNOWN & & & & \\
\hline 7772 & NOAA & UNKNOWN & & & & \\
\hline
\end{tabular}




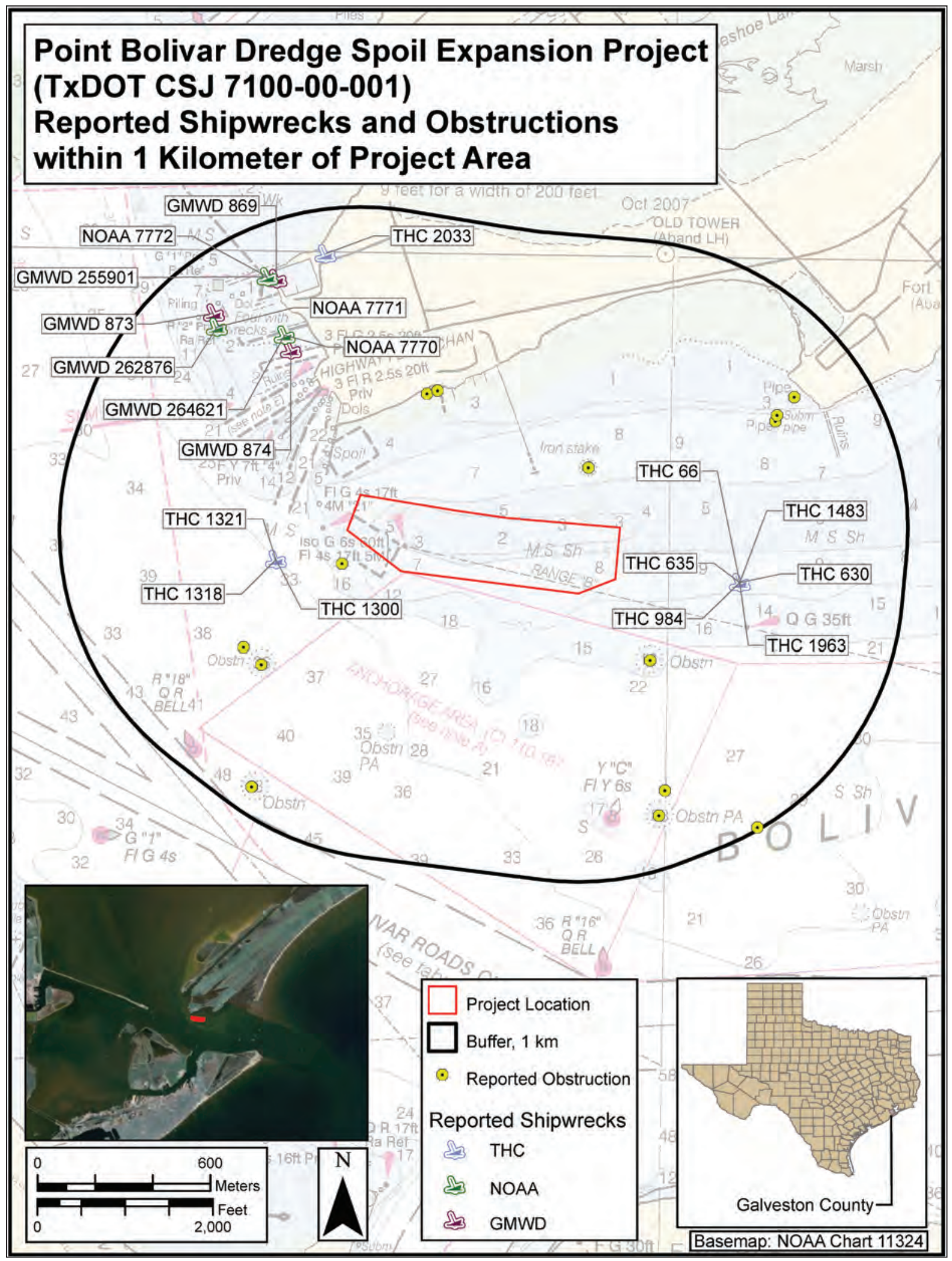

Figure A-1. Identified, previously recorded shipwrecks within one kilometer of the project area. 


\section{Point Bolivar Dredge Spoil Expansion Project (TxDOT CSJ 7100-00-001) Magnetic Contour Map}

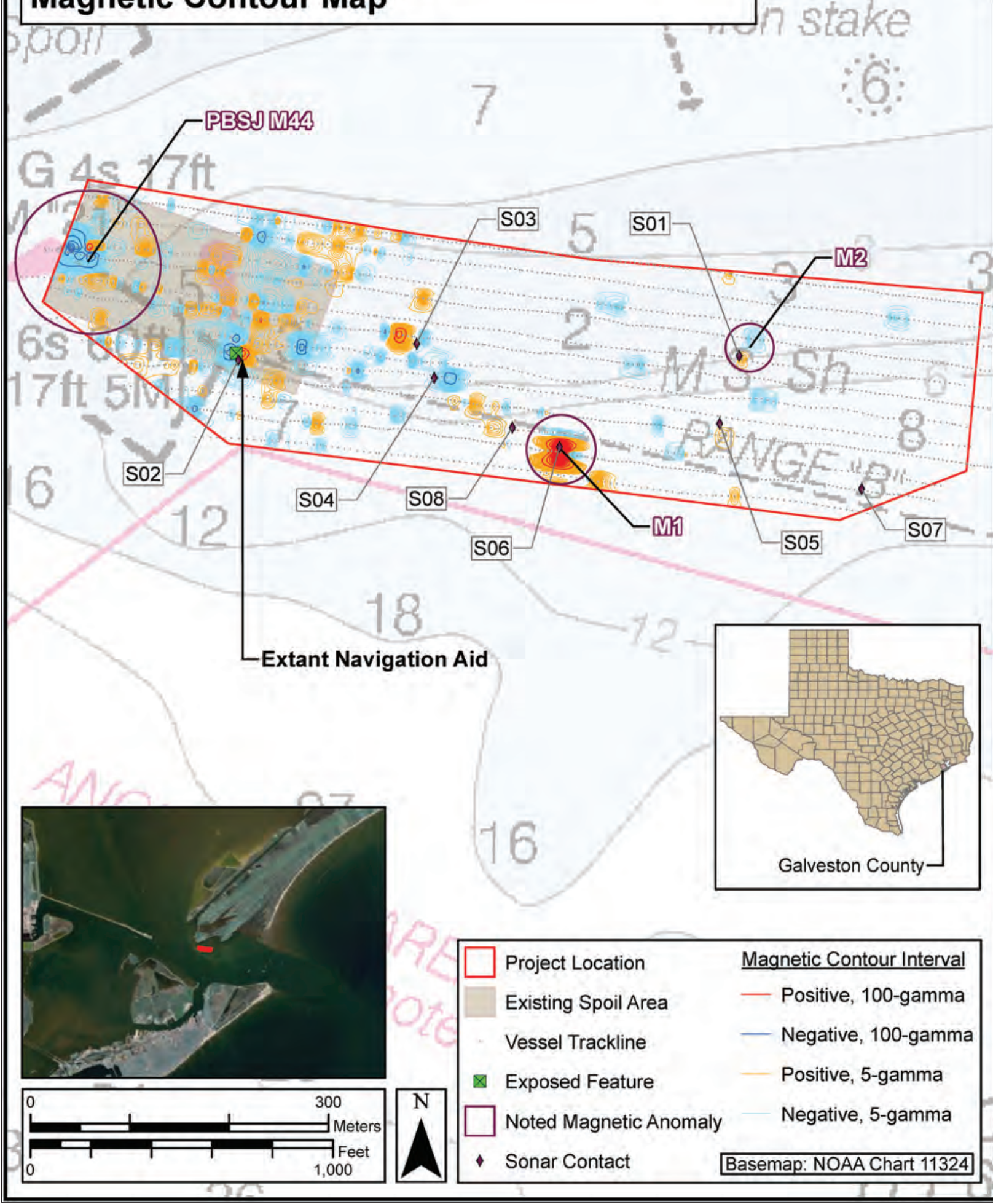

Figure A-2. Magnetometer survey contour map of the Bolivar Ferry dredge expansion survey area. 


\section{Point Bolivar Dredge Spoil Expansion Project (TxDOT CSJ 7100-00-001) Side-Scan Sonar Mosaic}

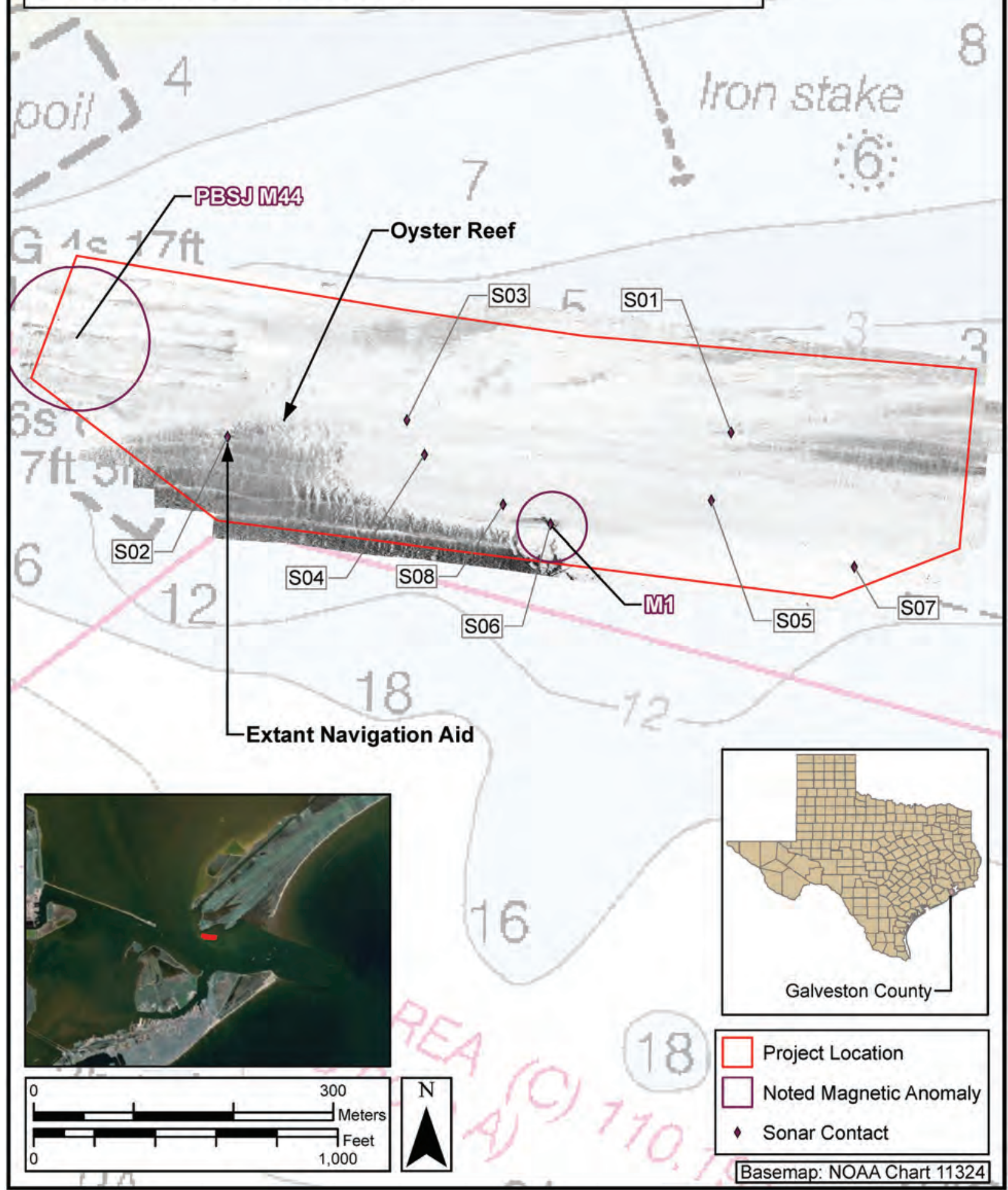

Figure A-3. Side Scan Sonar mosaic of the Bolivar Ferry dredge expansion survey area. 


\section{Appendix B Antiquities Permit Documentation}




\title{
TEXAS HISTORICAL COMMISSION
}

\author{
real places telling real stories
}

June 5,2012

Jeff Enright

Southeastern Archaeological Research, Inc.

428 E. Government Street

Pensacola, Florida 32502

Re: $\quad$ Project review under the Antiquities Code of Texas

Bolivar Dredge Placement Area, Galveston Bay, Tx (7100-00-001)

Texas Antiquities Permit Application \#6272

Dear Colleague:

Thank you for your Antiquities Permit Application for the above referenced project. This letter presents the final copy of the permit application from the Executive Director of the Texas Historical Commission, the state agency responsible for administering the Antiquities Code of Texas.

Please keep this copy for your records. The Antiquities Permit investigations requires the production and submittal of one printed copy of the final report, a completed abstract form submitted via our online system, two copies of the final report on a tagged PDF CD (one with site location information \& one without), and verification that any artifacts recovered and records produced during the investigations are curated at the repository listed in the permit. The abstract form maybe submitted via the THC website (www.thc.state.tx.us) or use url: https://106.thc.state.tx.us:4444/Abstract/Secure/index.aspx.

We would also like to request that shapefiles showing the boundaries of the project area and the areas actually surveyed be submitted via email to archeological projects@thc.state.tx.us.

If you have any questions concerning this permit or if we can be of further assistance, please contact Lillie Thompson at 512/463-1858. The reviewer for this project is Amy Borgens, 512/463-6096.

Sincerely,

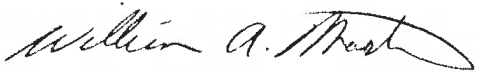

for

Mark Wolfe

Executive Director

$\mathrm{MW} / \mathrm{lft}$

Enclosures

Cc: Scott Pletka, Ph.D., TxDOT

Larry Laine, Tx GLO

RICK PERRY, GOVERNOR - SHERI S. KRAUSE, GHAIRMAN - WARK NOLFE, ERECUTIVE DIRECTOR

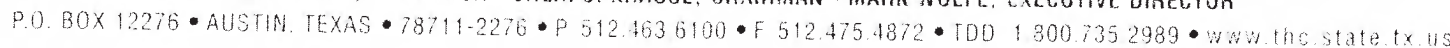




\section{- \\ State of Texas \\ TEXAS ANTIQUITIES COMMITTEE} ARCHEOLOGY PERMIT \# 6272

This permit is issued by the Texas Historical Commission, hereafter referred to as the Commission, represented herein by and through its duly authorized and empowered representatives. The

Commission, under authority of the Texas Natural Resources Code, Title 9, Chapter 191, and subject to the conditions hereinafter set forth, grants this permit for:

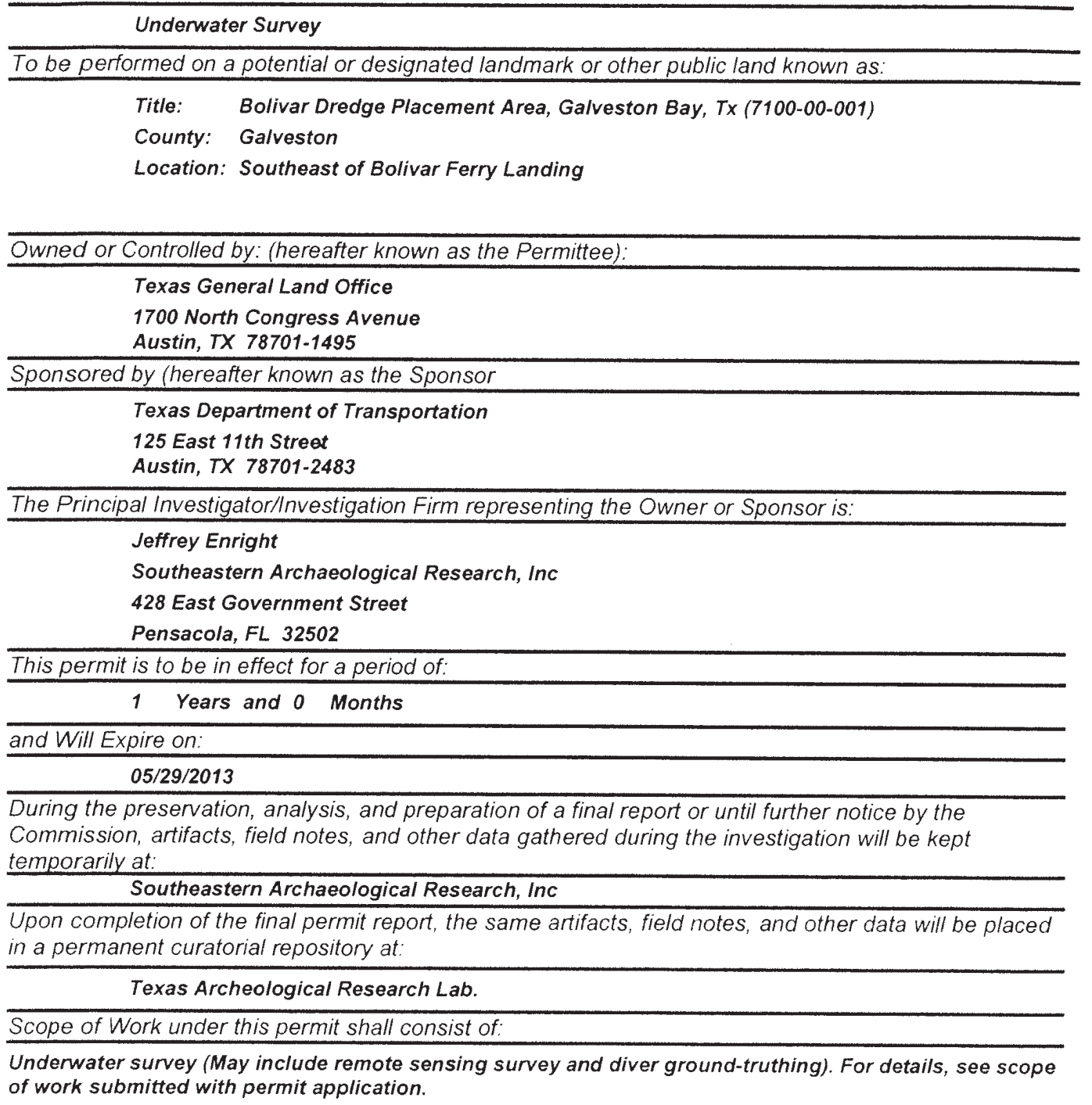




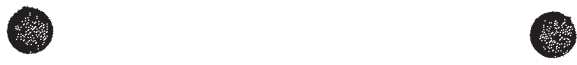

ARCHEOLOGY PERMIT\# 6272

This permit is granted on the following terms and conditions:

1) This project must be camed out in such a manner that the maximum amount of historic, scientific, archeological, and educational information will be recovered and preserved and must include the scientific, techniques for recovery, recording, preservation and analysis commonly used in archeological investigations. All survey level investigations must follow the state survey standards and the THC survey requirements established with the projects sponsor(s).

2) The Principal Investigator/Investigation Firm, serving for the Owner/Permittee and/or the Project Sponsor, is responsible for insuring that specimens, samples, artifacts, materials and records that are collected as a result of this permit are appropriately cleaned, and cataloged for curation. These tasks will be accomplished at no charge to the Commission, and all specimens, artifacts, materials, samples, and original field notes, maps, drawings, and photographs resulting from the investigations remain the property of the State of Texas, or its political subdivision, and must be curated at a certified repository. Verification of curation by the repository is also required, and duplicate copies of any requested records shall be furmished to the Commission before any permit will be considered complete.

3) The Principal Investigator/Investigation Firm serving for the Owner/Permittee, and/or the Project Sponsor is responsible for the publication of results of the investigations in a thorough technical report containing relevant descriptions, maps, documents, drawings, and photographs. A draft copy of the report must be submitted to the Commission for review and approval. Any changes to the draft report requested by the Commission must be made or addressed in the report, or under separate written response to the Commission. Once a draft has been approved by the Commission, one (1) printed, unbound copy of the final report containing at least one map with the plotted location of any and all sites recorded and two copies of the report in tagged PDF format on an archival quality CD or DVD shall be fumished to the commission. One copy must include the plotted location of any and all sites recorded and the other should not include the site location data. A paper copy and an electronic copy of the completed Abstracts in Texas Contract Archeology Summary Form must also be submitted with the final report to the Commission. (Printed copies of forms are available from the Commission or also online at www.thc. state.tx.us.)

4) If the Owner/Pemittee, Project Sponsor or Principal Investigator/Investigation Fim fails to comply with any of the Commission's Rules of Practice and Procedure or with any of the specific terms of this permit, or fails to property conduct or complete this project within the allotted time, the permit will fall into default status. A notification of Default status shall be sent to the Principal Investigatorilnvestigation Firm, and the Principal Investigator will not be eligible to be issued any new permits until such time that the conditions of this permit are complete or, if applicable, extended.

5) The Owner/Permittee, Project Sponsor, and Principal Investigator/Investigation Firm, in the conduct of the activities hereby authorizes, must comply with all laws, ordinances and regulations of the State of Texas and of its political subdivisions including, but not limited to, the Antiquities Code of Texas; they must conduct the investigation in such a manner as to afford protection to the rights of any and all lessees or easement holders or other persons having an interest in the property and they must retum the property to its original condition insofar as possible, to leave it in a state which will not create hazard to life nor contribute to the deterioration of the site or adjacent lands by natural forces.

6) Any duly authorized and empowered representative of the Commission may, at any time, visit the site to inspect the fieldwork as well as the field records, materials, and specimens being recovered.

7) For reasons of site security associated with historical resources, the Project Sponsor (if not the Owner/Permittee). Principal Investigator Owner, and Investigation Firm shall not issue any press releases, or divulge to the news media, either directly or indirectly, information regarding the specific location of, or other information that might endanger those resources, or their associated artifacts without first consulting with the Commission, and the State agency or political subdivision of the State that owns or controls the land where the resource has been discovered.

8) This permit may not be assigned by the Principal Investigator/Investigation Firm, Owner/Permittee, or Project Sponsor in whole, or in part to any other individual, organization, or corporation not specifically mentioned in this permit without the written consent of the Commission. 9) Hold Harm/ess: The Owner/Permittee hereby expressly releases the State and agrees that Owner/Permittee will hold harmless, indemnify, and defend (including reasonable attomey's fees and cost of litigation) the State, its officers, agents, and employees in their official and/or individual capacities from every liability, loss, or claim for damages to persons or property, direct or indirect of whatsoever nature arising out of, or in any way connected with, any of the activities covered under this permit. The provisions of this paragraph are solely for the benefit of the State and the Texas Historical Commission and are not intended to create or grant any rights, contractual or otherwise, to any other person or entity.

10) Addendum: The Owner/Permittee, Project Sponsor and Principal Investigator/Investigation Firm must abide by any addenda hereto attached.

Upon a finding that it is in the best interest of the State, this permit is issued on 05/29/2012

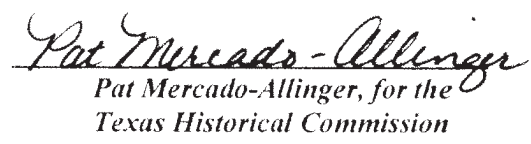

AmaTerra Environmental, Inc. 


\section{TEXAS HISTORICAL COMMISSION}

\section{ANTIQUITIES PERMIT APPLICATION UNDERWATER ARCHEOLOGY}

\section{GENERAL INFORMATION}

\section{PROPERTY TYPE AND LOCATION}

Project Name (and/or Site Trinomial) Survey at the Proposed Bolivar Dredge Placement Area, Galveston Bay, Texas (7100-00-001) County (ies)_ Galveston USGS Quadrangle or NOAA Chart Name and Number _ NOAA Galveston Bay Entrance Chart (11324)

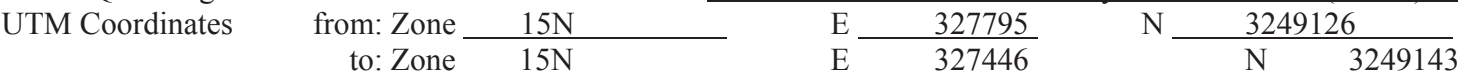
Location __ Southeast of Bolivar Ferry Landing
Federal Involvement
$\checkmark$ Yes
$\square$ No

Name of Federal Agency

Agency Representative

US Army Corps of Engineers and US Fish and Wildlife Service

\section{OWNER (OR CONTROLLING AGENCY)}

Owner _ Texas General Land Office

\begin{tabular}{ll} 
Representative & Robert Siddall \\
\cline { 2 - 2 } Address & $1700 \mathrm{~N}$. Congress Avenue
\end{tabular}

City/State/Zip _ Austin / Texas / 78701-1495

Telephone (include area code) $\quad 512-463-8530$

Email Address robert.siddall@glo.state.tx.us

III. PROJECT SPONSOR (IF DIFFERENT FROM OWNER)

Sponsor $\quad$ Texas Department of Transportation

Representative $\quad$ Scott Pletka

Address 125 E. $11^{\text {th }}$ Street

City/State/Zip Austin, TX 78701-2483

Telephone (include area code) 512-463-2633_Email Address $\quad$ spletka@txdot.gov

\section{PROJECT INFORMATION}

\section{PRINCIPAL INVESTIGATOR (ARCHEOLOGIST)}

Name Jeffrey M. Enright

Affiliation _. Southeast Archeological Research, Inc.

Address 428 East Government Street

City/State/Zip _ Pensacola, FL 32502

Telephone (include area code) _ 850-607-2846 Email Address jeff@searchinc.com

\section{PROJECT DESCRIPTION}

$\sqrt{ }$ Underwater survey (May include remote sensing survey and diver ground-truthing)

$\square$ Underwater testing

$\square$ Underwater site excavation (data recovery)

Texas Historical Commission

Archeology Division

P.O. Box 12276, Austin, TX 78711-2276

Phone 512/463-6096

www.thc.state.tx.us

TEXAS

HISTORICAL COMMISSION

The State Agency for Historic Preservation 


\section{ANTIQUITIES PERMIT APPLICATION UNDERWATER ARCHEOLOGY (CONTINUED)}

III. PERMIT DURATION (Maximum Allowed: Survey - 1 Year; Testing - 2 Years; Data Recovery - 4 Years)

Requested Permit Duration 1 year

Proposed starting date of fieldwork $5 / 29 / 12$

Proposed starting date of report preparation $\quad 6 / 15 / 12$

\section{ARTIFACT CONSERVATION AND CURATION}

Artifact Conservation Facility _ Southeastern Archeological Research, Pensacola, FL

Permanent Curatorial Facility Texas Archeological Research Laboratory

\section{FUNDING}

List funding sources to cover the costs of fieldwork, report preparation and artifact conservation and curation Texas Department of Transportation

\section{LAND OWNER'S CERTIFICATION}

I,__ Robert Siddall as legal representative of the Land Owner, Texas GLO_, do certify that I have reviewed the plans and research design and that no investigation will be preformed prior to the issuance of a permit by the Texas Historical Commission. Furthermore, I understand that the Owner, Sponsor and Principal Investigator are responsible for completing the terms of this permit.

Signature

Date

\section{SPONSOR'S CERTIFICATION}

I, Scott Pletka as legal representative of the Sponsor, TxDOT, do certify that I have reviewed the plans and research design and that no investigation will be preformed prior to the issuance of a permit by the Texas Historical Commission. Furthermore, I understand that the Sponsor, Owner and Principal Investigator are responsible for completing the terms of this permit.

Signature

Date

\section{PRINCIPAL INVESTIGATOR’S CERTIFICATION}

I, Jeffrey M. Enright , as Principal Investigator employed by SEARCH, Inc.. (Investigative Firm), do certify that I will execute this project according to the submitted plans and research design and will not conduct any work prior to the issuance of a permit by the Texas Historical Commission. Furthermore, I understand that the Principal Investigator (and the Investigative Firm), as well as the Owner and Sponsor, are responsible for completing the terms of this permit. Signature

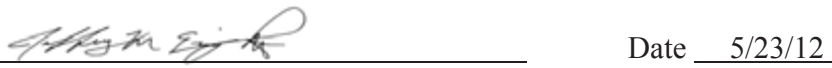

Principal Investigator must attach an outline of proposed work for survey and a research design for testing or data recovery, a copy of the USGS quadrangle or NOAA chart showing project boundaries, and any additional pertinent information. Curriculum vita of Principal Investigator must be on file with the Texas Historical Commission's Archeology Division.

\section{TEXAS HISTORICAL COMMISSION'S OFFICIAL USE ONLY}

Reviewer

Permit Number

Type of Permit
Date Permit Issued

Permit Expiration Date

Date Received for Data Entry 


\title{
Texas Department of Transportation
}

\section{BOLIVAR FERRY DREDGE SPOIL EXPANSION MARINE ARCHEOLOGICAL SURVEY SCOPE OF WORK}

CSJ No. 7100-00-001

\author{
Prepared by \\ Mason Miller \\ AmaTerra Environmental, Inc \\ and \\ Jeffrey M. Enright \\ Southeast Archeological Research, Inc.
}

May 23, 2012 


\section{Project Description}

The Texas Department of Transportation (TxDOT) has proposed to conduct new dredging activities at the Bolivar Ferry Landing at Point Bolivar in Galveston County, Texas (Attachment A). Dredge spoil has been deposited at a previously surveyed and designated disposal area to the southeast of the dredging site but additional area is now required to deposit the remaining sediments from the current effort. TxDOT has proposed to expand the existing dredge placement area and has received a temporary, one time clearance from the US Fish and Wildlife Service (USFWS) to deposit those materials at that location. The proposed dredge spoil expansion area is approximately $300 \times 700$ meters ( $984 \times 2,297 \mathrm{ft}$ ), covering a total area of about 51 acres (21 hectares; 67 acres including the existing, previously-surveyed dredge spoil pile; see Attachments A and B). Dredge excavation activities are not considered part of this project and are located within lands that have been previously surveyed. In reviewing the proposed expansion, the US Army Corps of Engineers (USACE), through their Galveston office, recommended the expansion be archeologically surveyed prior to use for compliance with Section 106 of the National Historic Preservation Act (Section 106) to assess the spoils deposition's potential for impacting submerged historic properties (cultural resources considered eligible for listing on the National Register of Historic Places [NRHP]; letter Kimberly McLaughlin to Pat Henry 2/17/2012). Additionally, this dredge pile is located within a state-owned (Texas General Land Office [GLO]) tract of submerged land (GLO Tract 136a) as a high-probability area for shipwrecks. Known significant shipwrecks and unidentified significant magnetic anomalies are located nearby. In initial project coordination, TxDOT received a similar recommendation for survey from the State Marine Archeologist at the Texas Historical Commission (THC).

From available information the undertaking's area of potential effects (APE) is defined as the threedimensional limits of impacts that could result from a federal undertaking. For this undertaking the APE is defined as the 67 acres of proposed dredge spoils with the majority of those impacts limited to the proposed 51acre expansion footprint. Impacts are anticipated to be limited to the submerged ground surface (or slightly below) that result from dumping dredged sediment. No private lands will be impacted by the proposed expansion and no PSLs or other facilities are anticipated.

Under the scope provided below, AmaTerra Environmental, Inc. (AmaTerra) working in conjunction with Southeastern Archeological Research, Inc. (SEARCH) will perform a Phase I marine remote-sensing survey to determine the presence or absence of potential submerged cultural resources in the expanded dredge placement area. If necessary, a second phase of investigations will directly inspect significant anomalies or 
sites identified during the Phase I survey. This work is being conducted to assist TxDOT with meeting its obligation under Section 106 and the ACT. All work will be conducted under the terms and conditions of the First Amended Programmatic Agreement (2005) among the Federal Highway Administration (FHWA), TxDOT, the THC and the Advisory Council on Historic Preservation and the Memorandum of Understanding (MOU) between TxDOT and the Texas Historical Commission (THC). The work will take place on public land controlled by the Texas General Land Office (GLO).

\section{Environmental Background}

Galveston Bay lies within the Gulf Coastal Plain Physiographic province and is the largest estuarine system in Texas. The bay covers approximately 600 square miles and averages 7-9 feet (2.1-2.7 meters) deep (Leatherwood 1996:53). The bay formed between 10,000 and 3,500 years before present (BP). Starting around 4,500 BP, longshore currents and waves transported eroded sands southwestward and formed spits and bars offshore from Galveston Bay (Fisher et al. 1990). Eventually, sedimentation accumulation resulted in the formation of Bolivar Peninsula, Galveston Island, and Follets Island. These barrier islands help buffer oceanic processes such as tides, currents, and waves within the bay. Galveston Bay sediments are dominated by Pleistocene and Late Holocene deposits consisting of sands, silts, and muds (Fisher et al. 1990). Recently, currents, eroding streams, and urbanization have altered the natural drainage of the modern bay-estuary lagoon system and increased deposition of sediment. Although the presence of barrier islands helps protect the Bay from extreme oceanic forces, its relatively shallow water, localized shoals, and oyster reefs created treacherous conditions for historic mariners, as they do for modern mariners. Once wrecked in Galveston Bay, the lower portion of a vessel would sink into the Holocene sediments while continuous sedimentation builds around it. As a result it is possible that a substantial portion of a shipwreck will remain buried and, in turn, preserved within Galveston Bay than in other, more open waterways.

\section{Background Research, Previous Investigations, and Potential for Historic Shipwrecks}

Galveston Bay has witnessed a rich maritime history that flourished in the 19th and 20th centuries. Prior to Mexican independence the region was largely ignored by the Spanish. Maritime traffic was limited to few exploration, trade, and pirating enterprises. The likelihood of shipwrecks in Galveston Bay dating to this period is low. As Galveston rose to preeminence as a Texas port, and small communities sprouted along the shores of Galveston Bay to support the movement of goods and people inland, traffic in the bay proliferated. There are numerous documented accounts of small vernacular craft plying the waters of Galveston Bay beginning in the 1820 s, while steamboats became a regular site in the bay between the late 1830s and the turn of the century. Sloops, schooners, barges, and steamboats criss-crossed Galveston Bay between the port of Galveston and burgeoning communities like Anáhuac, Harrisburg, and Houston. Throughout the late 19th and early 20th centuries smaller, wooden-hull sailing vessels were replaced with larger iron and steel workboats powered by 
steam and gasoline engines. The increase in vessel traffic starting in the early 1800 s, coupled with geologic factors like the shallowness of the bay, numerous shoals, and oyster reefs, and climatic factors like the propensity of strong northers and hurricanes in the region, increases the potential for wrecking events in Galveston Bay during this time period. Later, the creation of various shipping channels in Galveston Bay, especially the Houston Ship Channel and its precursor, focused maritime transportation into narrow corridors; shipwreck events decreased as a result.

The documented abundance of small, wooden-hull sailing vessels between 1820 and 1900 likely will account for a significant portion of historic shipwrecks in Galveston Bay. This category of shipwreck will appear in the remote-sensing data as relatively smaller, lower amplitude magnetic anomalies with lower amplitude gradients. There likely would exist little to no side-scan sonar image associated with this vessel type due to the propensity of exposed wood to deteriorate rapidly in a marine environment, and a sufficient passage of time to bury any remaining structure. A somewhat less likely, but potential category of historic shipwrecks in Galveston Bay is the wooden-hull steamboat. An anomaly associated with this vessel type would be relatively larger and higher in amplitude, with a corresponding amplitude gradient. A side-scan sonar target could exist for this vessel type and might consist of exposed individual or complex concentrations of iron steam engine components. This image might not be identifiable as a shipwreck due to a lack of surviving, exposed hull. The 20th century workboat is another category of shipwreck to expect in Galveston Bay. This category likely constitutes a significant percentage of shipwrecks in the bay. Many of these shipwrecks will be located in close proximity to navigation channels. The magnetic anomaly of an iron or steel vessel propelled with a steam or gasoline engine would be strikingly large and intense, with a much higher amplitude gradient than other historic vessels. The hull and machinery are more likely to have survived in some form above the sediment level; therefore, there exists a high potential of recording a recognizable side-scan sonar image.

Another tool that the Team utilized to help identify potential submerged cultural resources within or adjacent to the project corridor consists of secondary sources and databases of reported shipwrecks. These sources include the THC Office of the State Marine Archeologist shipwreck files, Texas Historic Sites Atlas, the National Oceanic and Atmospheric Administration's (NOAA) Automated Wreck and Obstruction Information System (AWOIS), NOAA nautical charts, Merchant Vessels of the United States /Merchant Vessel Losses of the United States (United States Coast Guard), and other proprietary shipwreck databases. Table 1 lists shipwrecks that have been reported within one kilometer of the current project's archeological APE. 
Table 1: Recorded Shipwrecks within One Kilometer of Current Project Area

\begin{tabular}{|r|l|l|l|l|l|l|}
\hline \multicolumn{1}{|l|}{ ID } & Source & Name & $\begin{array}{l}\text { Year } \\
\text { Lost }\end{array}$ & SAL & Vessel Type & $\begin{array}{l}\text { Positional } \\
\text { Accuracy }\end{array}$ \\
\hline 66 & THC & LE COMPTE & 1865 & Yes & $\begin{array}{l}\text { sailing ship, } \\
\text { merchant }\end{array}$ & 1 mile \\
\hline 630 & THC & PEARL RIVERS & 1879 & Yes & $\begin{array}{l}\text { sailing ship, } \\
\text { merchant }\end{array}$ & \\
\hline 635 & THC & TOM BROWN & 1851 & Yes & sail-steam, merchant & \\
\hline 984 & THC & BEARDSTOWN & 1875 & Yes & sail-steam, merchant & \\
\hline 1300 & THC & UNKNOWN & 1970 & No & unknown & \\
\hline 1318 & THC & UNKNOWN & 1971 & No & unknown & \\
\hline 1321 & THC & UNKNOWN & 1970 & No & unknown & \\
\hline 1483 & THC & SCANDANAVIAN & 1895 & Yes & $\begin{array}{l}\text { sailing ship, } \\
\text { merchant }\end{array}$ \\
\hline 1963 & THC & CLIMAX & 1831 & No & sailing ship & \\
\hline 2033 & THC & LITTE DORA & 1915 & No & Unknown & \\
\hline 869 & GMWD & UNKNOWN & 1934 & & & \\
\hline 873 & GMWD & UNKNOWN & 1934 & & & \\
\hline 874 & GMWD & UNKNOWN & 1934 & & & \\
\hline 255901 & GMWD & UNKNOWN & & & & \\
\hline 262876 & GMWD & UNKNOWN & & & & \\
\hline 264621 & GMWD & UNKNOWN & & & & \\
\hline 7770 & NOAA & UNKNOWN & & & & \\
\hline 7771 & NOAA & UNKNOWN & & & & \\
\hline 7772 & NOAA & UNKNOWN & & & & \\
\hline & & & & & \\
\hline
\end{tabular}

According to the THC's Sites Atlas there are three recorded shipwreck locations in the general project vicinity (within approximately 1000 meters of the APE). Closest to the study area is a mapped unknown wreck from 1970, while farther to the southeast, historical records indicate that seven individual wrecks are located in the general area (Le Compte 1865, Pearl Rivers 1879, Tom Brown 1851, Beardstown 1875, Scandinavian 1895, and Climax 1831). With the exception of Climax all of these vessels are listed State Archeological Landmarks (SALs) though their specific location could not be determined. The 1910-dated wreck of Little Dora is documented on the interior shoreline of point Bolivar is not listed as a SAL and is not likely to be impacted by the current dredge spoil expansion. No other wrecks are reported in the vicinity.

A 2004 marine remote sensing and hydroprobing survey by archeologists from Coastal Environments and PBS\&J for TxDOT's proposed third Bolivar Ferry Landing was conducted immediately to the west of the current dredge location and in the vicinity of the proposed expansion footprint (TAC Permit 3346). One magnetic anomaly was identified during survey and subsequently hydroprobed and found to not be a likely shipwreck. THC, having instated a 40-meter-radius avoidance zone around the anomaly, removed the avoidance and recommended the project could proceed with no properties affected (letter Lain Ellis to Steve 
Hoyt 7/22/2004). The western-most third of the proposed dredge expansion area has been previously surveyed through remote sensing by marine archeologists from PBS\&J in 2007 on behalf of TxDOT (TAC Permit 4467). This Galveston-Bolivar Causeway survey identified two high probability areas (HPAs) recommended for avoidance (M44 and M45) whose avoidance zone boundaries are located adjacent to or within the current survey corridor (see Appendix A). These HPAs are located in non-expansion portions of the APE but will be of particular interest to the survey team to assure that proposed spoils deposition will not impact them. No other surveys have been conducted that overlap or lie directly adjacent to the currently-proposed dredge expansion APE.

\section{Scope of Work}

Phase I Survey and Data Processing

AmaTerra will utilize remote-sensing equipment and a methodology that follows the THC's standards for conducting remote-sensing surveys, as stated in the Title 13, Part 2, Chapter 28 of the Texas Administrative Code (13 TAC 28). The survey will be limited to the 51 acres of proposed dredge spoils expansion rather than the entire 67-acre APE as the original dredge spoil pile has been previously investigated, cleared, and is likely heavily disturbed. Equipment for the survey will include a differentially-corrected global positioning system receiver (GPS), a cesium magnetometer, a side-scan sonar, and an echo-sounder. Survey will be conducted along preplanned transects spaced no greater than 20 meters apart. Approximately one third (the western third) of the proposed dredge expansion area has been surveyed previously. The eastern portion has not been surveyed and measures approximately 700 meters (east-west) x 300 meters (north-south), which equates to 15 roughly east-west transects and a total of approximately 10.5 linear survey kilometers. Vessel speed will be dependent upon sea conditions, but should average approximately 4.5 knots.

HYPACK navigation software will provide vessel guidance and data logging for positional, magnetic, and bathymetric data. The GPS, magnetometer, and echo-sounder will gather data at a rate of 1 reading per second, which will provide an in-line data spacing of approximately 2.3 meters. The GPS will be interfaced with the side-scan sonar acquisition system, and positional data will be embedded into the graphics to facilitate subsequent processing and target identification. The side-scan sonar will be set to image the seafloor at a $25-\mathrm{m}$ (82-foot) range (i.e. 50-m total swath width). This range setting is sufficient to overlap the nadir region beneath the towfish and provide 100-percent imagery coverage. Methods similar to these are generally considered the operational standard for marine remote sensing survey in the area and have the greatest potential for identifying submerged cultural resources while remaining functionally practical. No artifacts will be collected during the survey.

Processing of Phase I survey data will be conducted to determine the presence/absence of potential submerged cultural resources and the need for subsequent target identification. Data processing will include 
generating a magnetic contour map of the survey area and a review of the raw side-scan sonar imagery. Any sonar contacts will be correlated with the magnetic contour map to assist with archaeological interpretation. All project data will be incorporated into a GIS geo-database, following demobilization from the field effort, for organization, interpretation, and display. Magnetic data interpretation involves comparison of anomalies recorded within the project corridor to previously documented and verified shipwreck anomalies, and an analysis of anomaly characteristics that help differentiate potential submerged cultural resources from debris.

Shortly after concluding field survey, AmaTerra will submit an electronic interim report (via email) of their findings to TxDOT-ENV for review and forward to the THC. Included with this interim report will be a basic survey narrative, a list of magnetic anomalies and side-scan sonar contacts identified as potential submerged cultural resources, a map depicting the location of recommended anomalies and contacts, and recommendations for avoidance or further investigation. If anomalies and/or contacts are identified that, through coordination, require additional investigations to assess their identities and make a preliminary assessment of NRHP eligibility, AmaTerra will mobilize for the Target Investigation phase of fieldwork that will be coordinated through TxDOT and the office of the State Marine Archeologist separately.

\section{Target Investigation (Insert text)}

If targets are identified that require direct investigation, a dive team will be readied to visually inspect each target (up to a maximum of three targets). AmaTerra will develop a diving operations and safety plan and coordinate proposed dive operations with the US Coast Guard prior to initiating the field effort. These forms and copies of correspondence will be provided to TxDOT for their records throughout this process. Pre-/postfield mobilization/demobilization will include equipment checks and loading/unloading, dive vessel rental and mobilization (a 32-foot flat-deck vessel), travel to/from the study area, and equipment setup/removal on the dive vessel.

Using GPS data gathered from the survey, each target will be relocated and inspected by divers. A crew of five is proposed for the target investigations to cover all tasks in the water and on the boat (diving, communications, tending, etc.). Targets that are found to protrude above the bottom will be visually inspected and documented. Targets that do not extend above the soil surface will be investigated by hydro-probing at an interval determined by the Principal Investigator and environmental conditions. All work conducted under the target investigation phase will be guided by safety protocol outlined in the USACE's EM 385-1-1 safety regulations. Hard-hat diving with surface-supplied air will be used with hard-wired communication maintained between individual divers and the topside crew. Each target will be assessed for size, composition, age, and integrity in an effort to identify the target and make a preliminary assessment of its eligibility for listing as a Historic Property and/or as a State Archeological Landmark (SAL). 
Once each target has been fully assessed, AmaTerra will provide TxDOT with a brief interim report detailing the findings. This report will summarize the archeologists' assessment of each target and provide preliminary recommendations for NRHP/SAL eligibility and/or the need for any further work. This report will be submitted electronically to TxDOT via email for review and forward to the THC.

\section{Reporting and Curation}

Following review and comment of the interim electronic report and additional field efforts (if necessary), the Team will prepare a technical report following the Council of Texas Archeologists format, as required in the ACT and the project's Texas Antiquities Permit (13 TAC 26.24). This report will include a summary of archival and background information, a survey narrative, a list of sites/anomalies identified along with their recommended NRHP/SAL eligibility, and recommendations for further work (if any) necessary for compliance with Section 106 and the ACT (36 CFR 800, 13 TAC 26.20). Four copies of the draft report will be submitted to TxDOT-ENV for review and comment and ultimately forwarded to the State Marine Archeologist and cultural resource staff at the USACE's Galveston office for review and approval. Once approved by all reviewing parties, the requisite number of final report copies (both hard copies and tagged PDF electronic copies on $\mathrm{CD}$ ) will be supplied to TxDOT, the THC and the USACE in compliance with permitting requirements (13 TAC 26.24). One version of this final report will remove all site locational data and will be distributed to libraries for public reference while the others will be unabridged and retained by regulatory agencies.

AmaTerra does not intend to collect any artifacts in the field during either phase of investigations and will rather rely on notes, photographs, and other methods to document any objects that are observed. Field notes, forms, and other materials will be curated at the Texas Archeological Research Laboratory in the event that an archeological site is documented. Otherwise, those materials will be kept at the respective offices of SEARCH and AmaTerra.

\section{References Cited}

Fisher, W. L., J. H. McGowen, L. F. Brown, Jr., and C. G. Groat

1990 Environmental Geologic Atlas of the Texas Coastal Zone - Galveston-Houston Area. Bureau of Economic Geology, The University of Texas at Austin.

Leatherwood, A.

1996 "Galveston Bay" in The New History of Texas, vol. 3, pg. 53. The Texas State Historical Association, Austin. 
Attachment A: Project Location Map

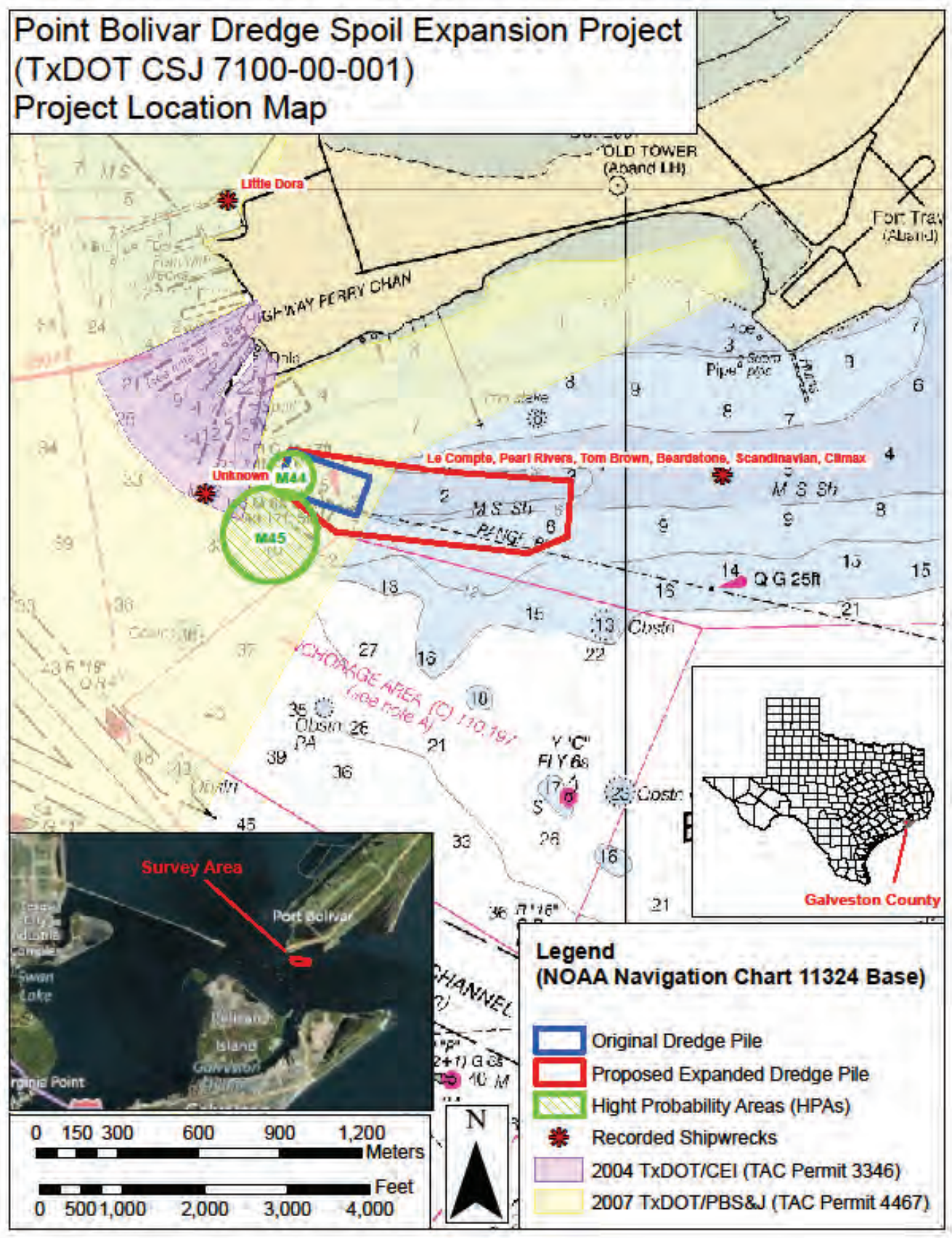




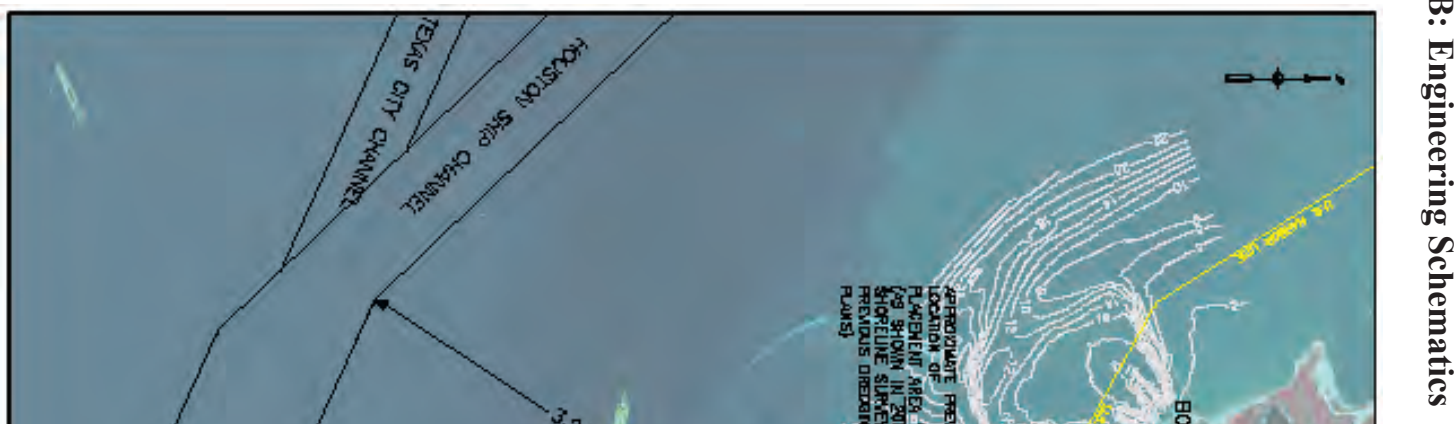

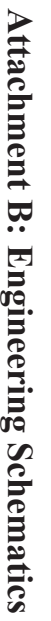




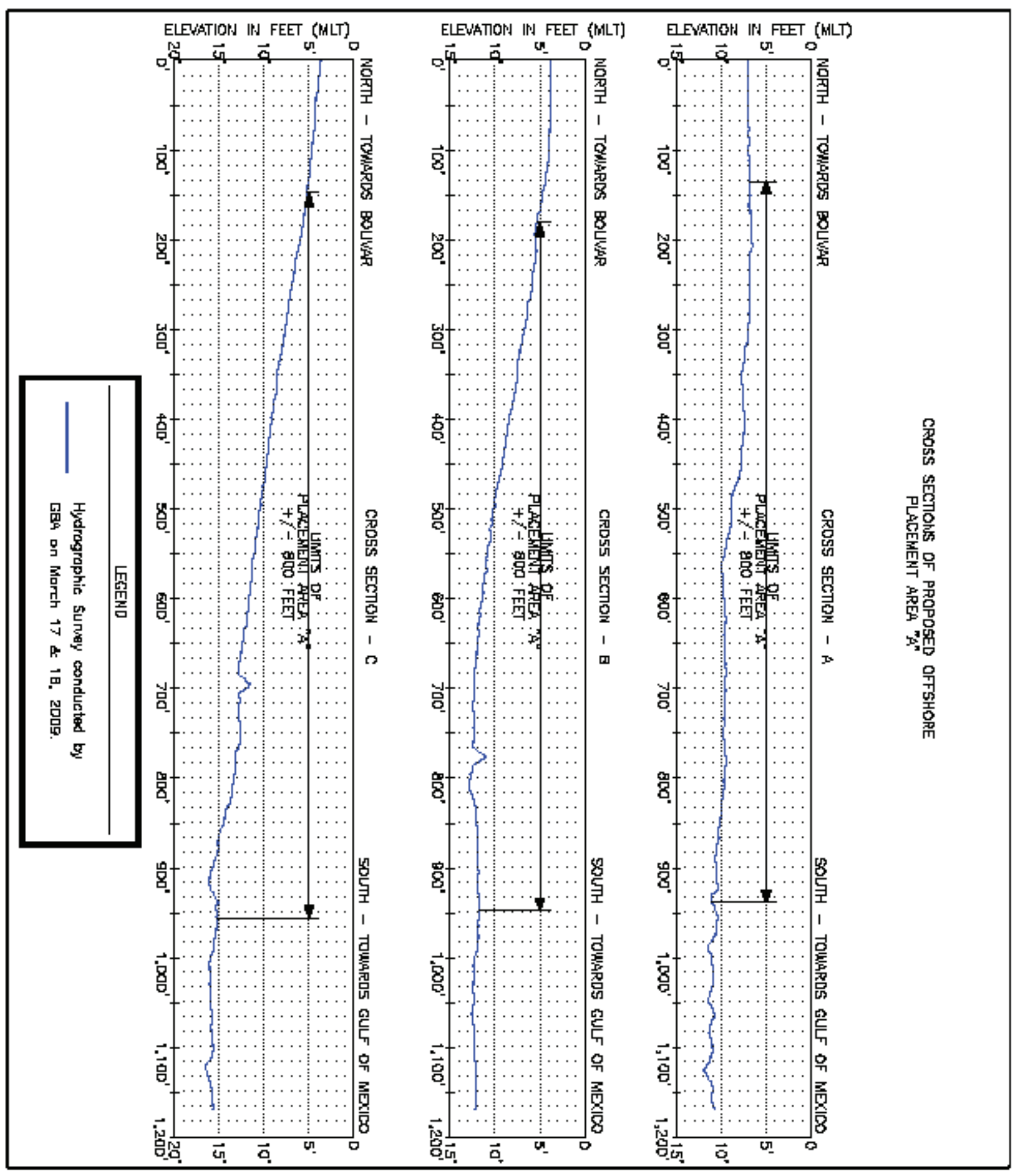

\begin{tabular}{|c|c|c|c|c|}
\hline \multicolumn{2}{|c|}{ APPLICUKT: TESAS DEPARTHTRT DF TRUNGPDRTATIDN } & \multirow{4}{*}{ 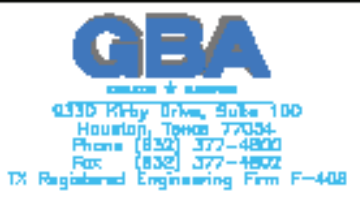 } & \multicolumn{2}{|c|}{ FOR COE USE ONLY } \\
\hline \multirow{2}{*}{\multicolumn{2}{|c|}{ 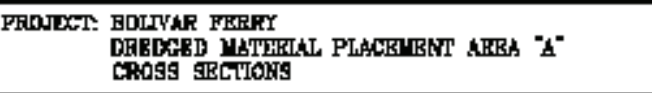 }} & & \multicolumn{2}{|c|}{ Permit Applicant \#: } \\
\hline & & & \multicolumn{2}{|c|}{ Applicant Name: } \\
\hline COONMT: AALPBSTOH & RJFY, DA'TB & & SCALE: ASINDICATED & SHEET 3 OF 4 \\
\hline
\end{tabular}




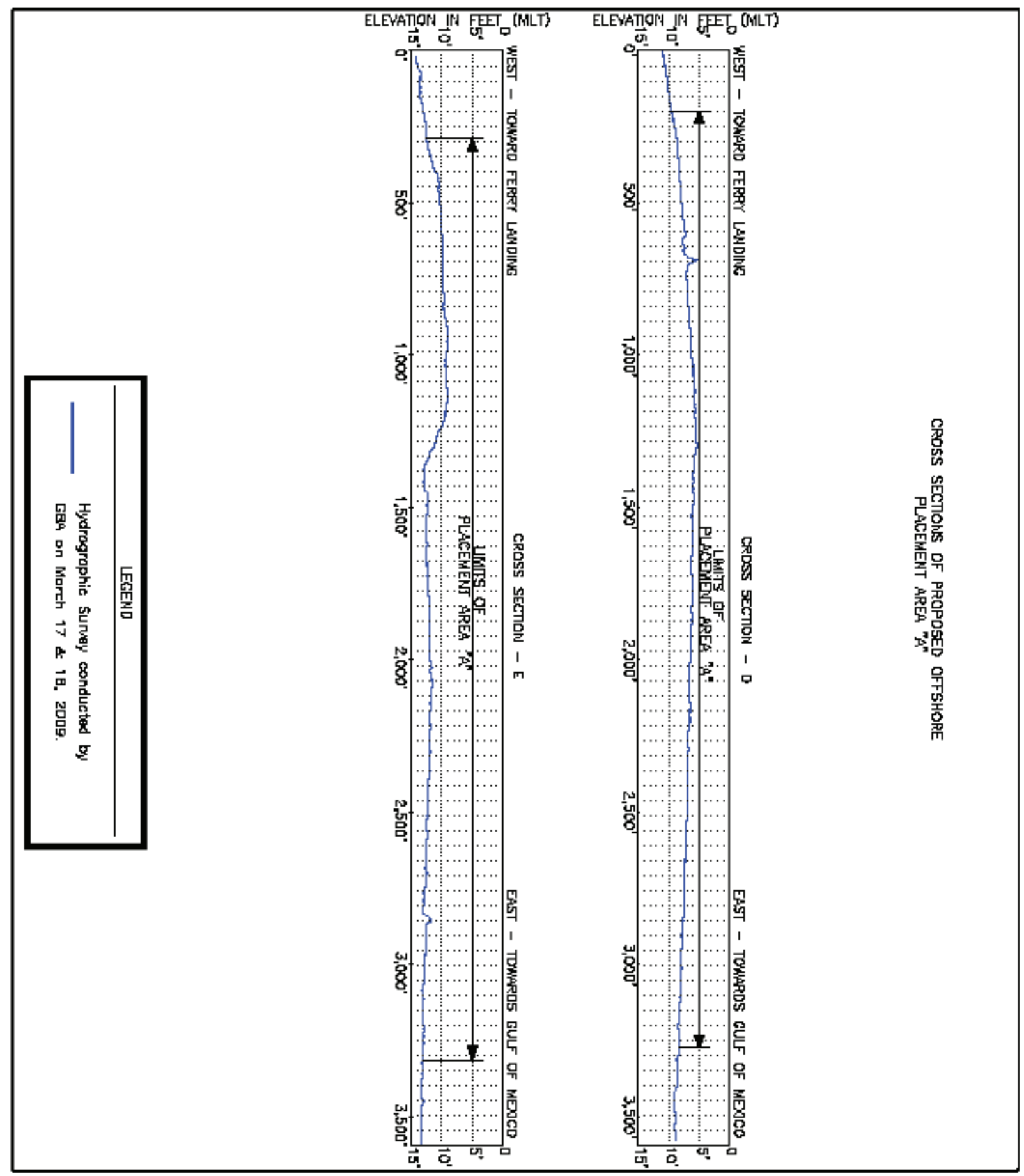

\begin{tabular}{|c|c|c|c|c|c|}
\hline \multicolumn{3}{|c|}{ APPLICUNT: TESAS DEPARTHENT DF TRUNSPDETATIDN } & \multirow{4}{*}{ 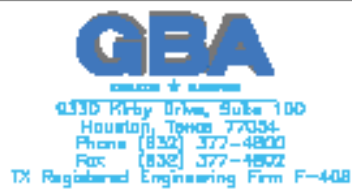 } & \multicolumn{2}{|c|}{ FOR COE USE ONLY } \\
\hline \multirow{2}{*}{\multicolumn{3}{|c|}{ 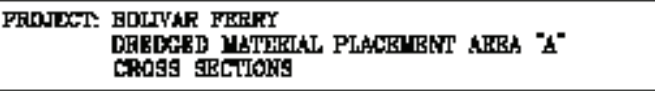 }} & & \multicolumn{2}{|c|}{ Permit Applicant \#: } \\
\hline & & & & \multicolumn{2}{|c|}{ Applicant Name: } \\
\hline & COOMT: AALFESTON & REY, DATB & & SCALE: ASINDICATED & SHEET 4 OF \\
\hline
\end{tabular}




\section{Appendix C \\ Remote-Sensing Survey Log}


Appendix C Remote-Sensing Survey Log 


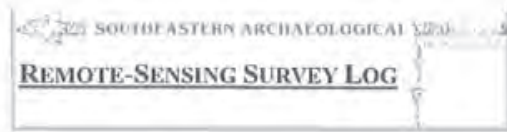

Start Date: $M$ A 31 Lo/2

End Date: May $31 \quad 2012$

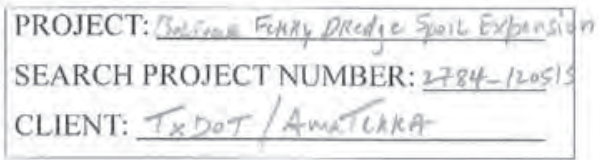

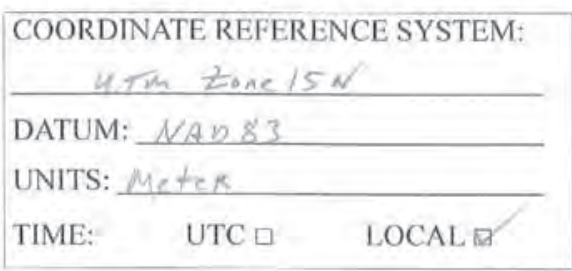

Lead Surveyor: Ji EnRight Crew: D. kobents, M. Millek
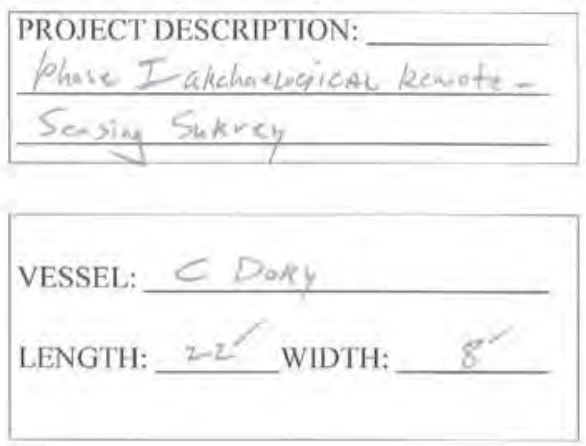

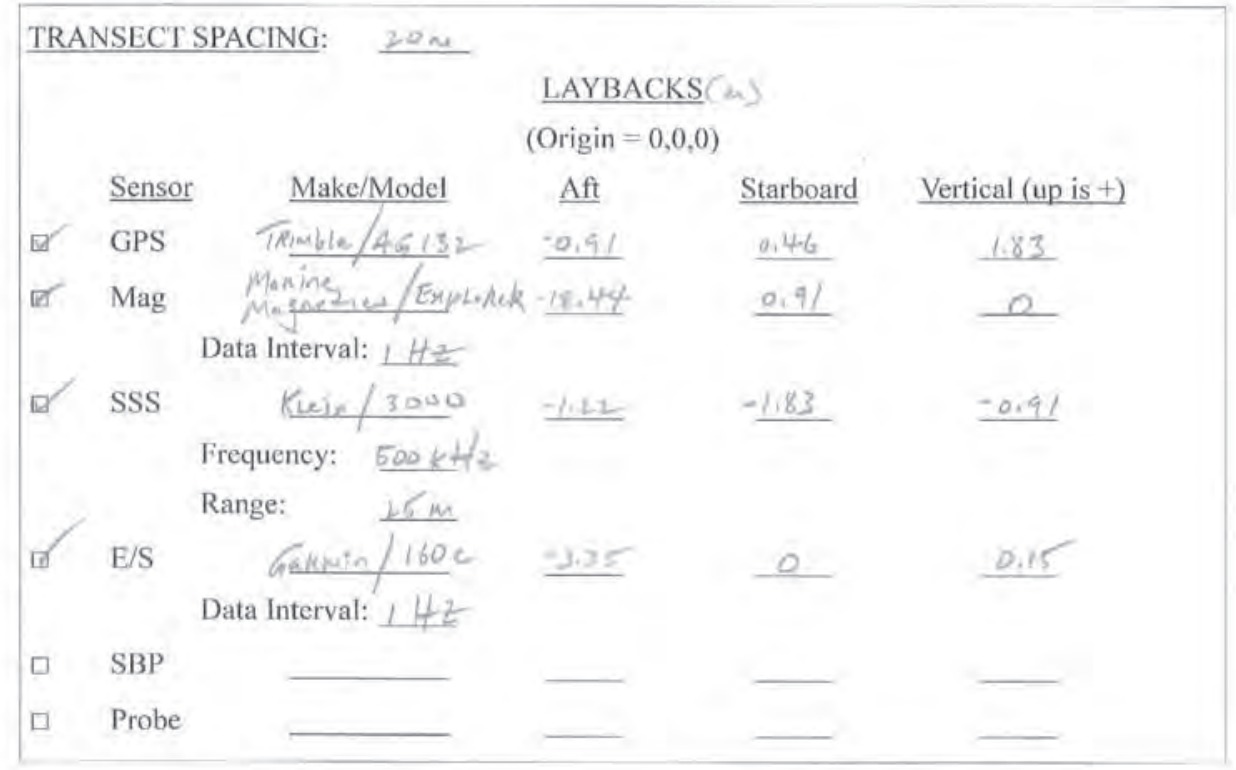

NOTES:

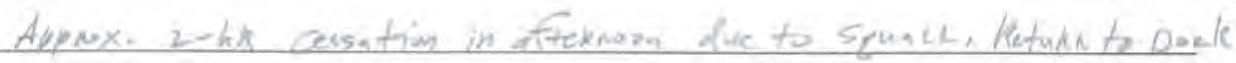

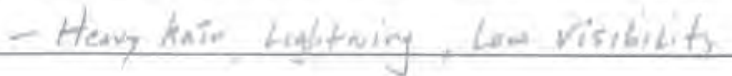


Appendix C Remote-Sensing Survey Log 


\section{Appendix D \\ Side-Scan Sonar Contact Report}




\section{Contact Report: Bolivar Ferry SSS Contacts}

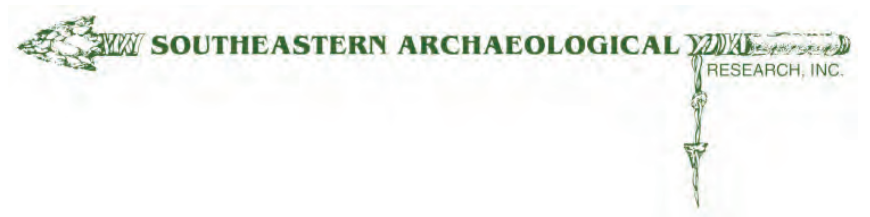

Report file: Bolivar_Ferry_SSS_Contacts.doc Generated on: $06 / 25 / 2012$ 03:29:19 PM

By: targetReportGen2 V3.15.15

(Projection: UTM83-15)

Contacts in this report:

S01
S02
S02_duplicate
S03
S04
S05
S05_duplicate
S06
S06_duplicate
S07
S08

S01

S02

S03

$\mathrm{SO4}$

S05_duplicate

S06

S07

S08 $\begin{array}{ll}\text { 05/31/2012 } & 13: 36: 33 \\ \text { 05/31/2012 13:59:24 } \\ \text { 05/31/2012 15:43:40 } \\ \text { 05/31/2012 14:00:22 } \\ \text { 05/31/2012 16:17:59 } \\ \text { 05/31/2012 16:19:38 } \\ \text { 05/31/2012 16:24:49 } \\ \text { 05/31/2012 16:32:57 } \\ \text { 05/31/2012 16:39:43 } \\ \text { 05/31/2012 16:34:37 } \\ \text { 05/31/2012 } 16: 40: 07\end{array}$

\begin{abstract}
29.3575975862 Lat 29.3574894370 Lat 29.3574901734 Lat 29.3576626209 Lat 29.3573544633 Lat 29.3569785386 Lat 29.3570029816 Lat 29.3567428459 Lat 29.3567601421 Lat 29.3564020815 Lat 29.3569135690 Lat
\end{abstract}

-94.7709304028 Lon -94.7761266259 Lon -94.7761259647 Lon -94.7742791781 Lon -94.7740900772 Lon -94.7711233169 Lon -94.7711162059 Lon -94.7727796030 Lon -94.7727726779 Lon -94.7696379609 Lon -94.7732712896 Lon 


\section{Report: Bolivar Ferry SSS Contacts}

Generated on: 06/25/2012 03:29:19 PM by SonarWiz.MAP targetReportGen2 V3.15.15

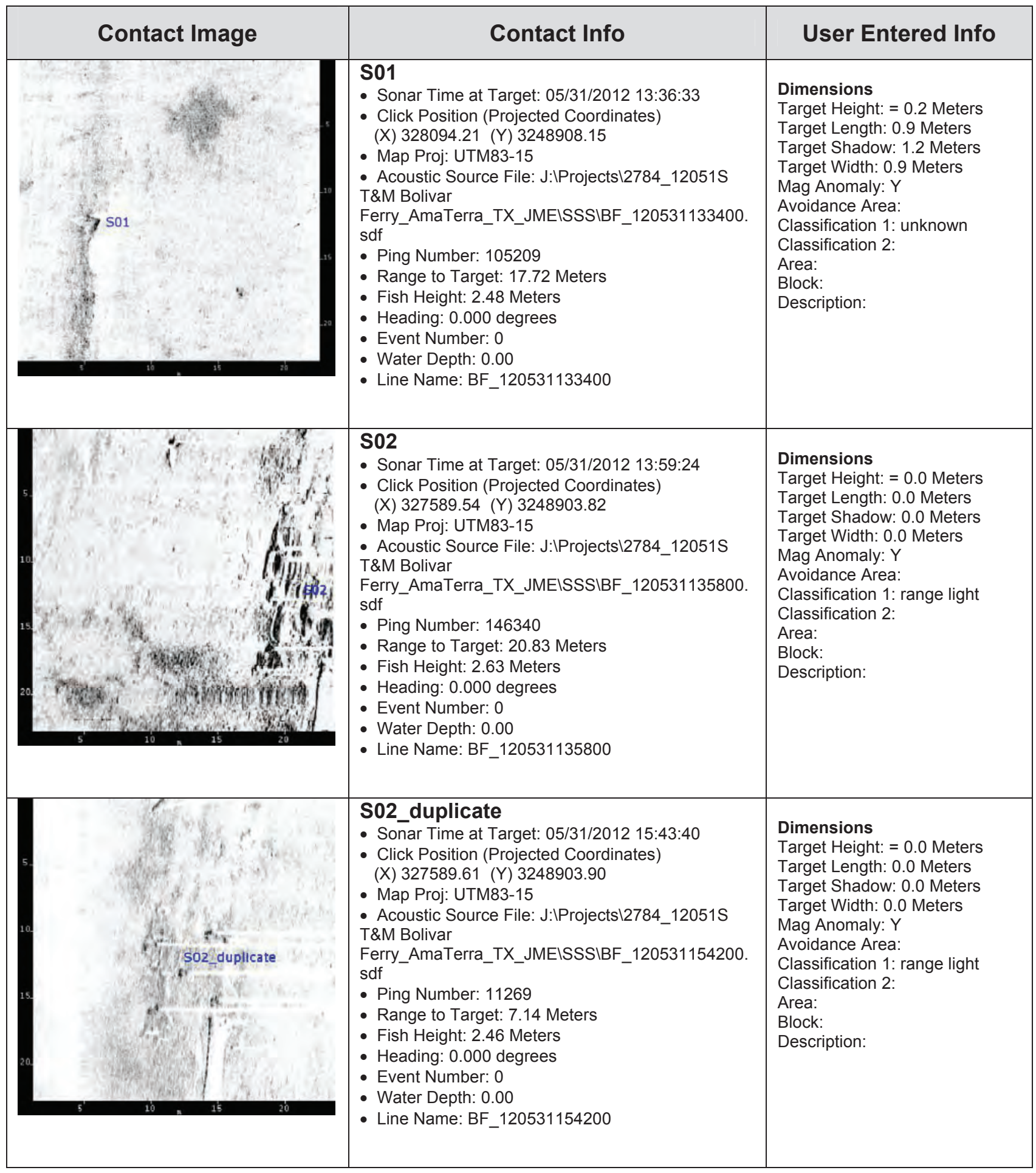




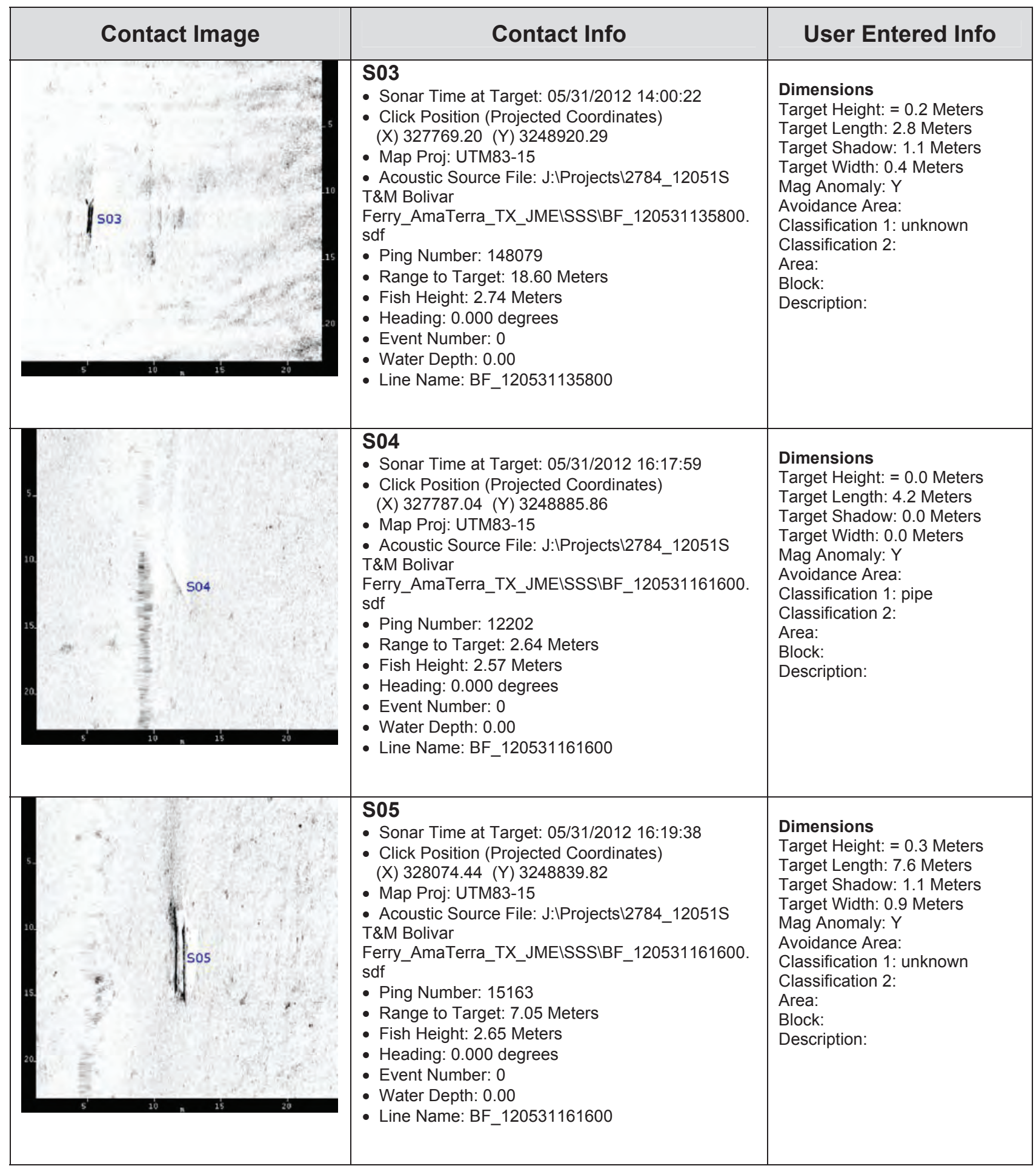




\begin{tabular}{|c|c|c|}
\hline Contact Image & Contact Info & User Entered Info \\
\hline & $\begin{array}{l}\text { S05_duplicate } \\
\text { - Sonar Time at Target: 05/31/2012 16:24:49 } \\
\text { - Click Position (Projected Coordinates) } \\
\text { (X) } 328075.17 \text { (Y) 3248842.52 } \\
\text { - Map Proj: UTM83-15 } \\
\text { - Acoustic Source File: J:IProjectsI2784_12051S } \\
\text { T\&M Bolivar } \\
\text { Ferry_AmaTerra_TX_JMEISSSIBF_120531162200. } \\
\text { sdf } \\
\text { - Ping Number: } 24473 \\
\text { - Range to Target: } 14.89 \text { Meters } \\
\text { - Fish Height: } 3.15 \text { Meters } \\
\text { - Heading: 0.000 degrees } \\
\text { - Event Number: } 0 \\
\text { - Water Depth: } 0.00 \\
\text { - Line Name: BF_120531162200 }\end{array}$ & $\begin{array}{l}\text { Dimensions } \\
\text { Target Height: }=0.0 \text { Meters } \\
\text { Target Length: } 0.0 \text { Meters } \\
\text { Target Shadow: } 0.0 \text { Meters } \\
\text { Target Width: } 0.0 \text { Meters } \\
\text { Mag Anomaly: Y } \\
\text { Avoidance Area: } \\
\text { Classification 1: unknown } \\
\text { Classification 2: } \\
\text { Area: } \\
\text { Block: } \\
\text { Description: }\end{array}$ \\
\hline 4. & $\begin{array}{l}\text { S06 } \\
\text { - Sonar Time at Target: 05/31/2012 16:32:57 } \\
\text { - Click Position (Projected Coordinates) } \\
\text { (X) } 327913.24 \text { (Y) 3248816.14 } \\
\text { - Map Proj: UTM83-15 } \\
\text { - Acoustic Source File: J:IProjectsI2784_12051S } \\
\text { T\&M Bolivar } \\
\text { Ferry_AmaTerra_TX_JMEISSSIBF_120531163000. } \\
\text { sdf } \\
\text { - Ping Number: } 39113 \\
\text { - Range to Target: } 14.24 \text { Meters } \\
\text { - Fish Height: } 3.02 \text { Meters } \\
\text { - Heading: 0.000 degrees } \\
\text { - Event Number: } 0 \\
\text { - Water Depth: } 0.00 \\
\text { - Line Name: BF_120531163000 }\end{array}$ & $\begin{array}{l}\text { Dimensions } \\
\text { Target Height: = } 1.0 \text { Meters } \\
\text { Target Length: } 17.4 \text { Meters } \\
\text { Target Shadow: } 7.4 \text { Meters } \\
\text { Target Width: } 5.6 \text { Meters } \\
\text { Mag Anomaly: Y } \\
\text { Avoidance Area: } \\
\text { Classification 1: range light } \\
\text { Classification 2: } \\
\text { Area: } \\
\text { Block: } \\
\text { Description: }\end{array}$ \\
\hline . & $\begin{array}{l}\text { S06_duplicate } \\
\text { - Sonar Time at Target: 05/31/2012 16:39:43 } \\
\text { - Click Position (Projected Coordinates) } \\
\text { (X) } 327913.94 \text { (Y) } 3248818.05 \\
\text { - Map Proj: UTM83-15 } \\
\text { - Acoustic Source File: J:IProjects|2784_12051S } \\
\text { T\&M Bolivar } \\
\text { Ferry_AmaTerra_TX_JMEISSSIBF_120531163600. } \\
\text { sdf } \\
\text { - Ping Number: } 51287 \\
\text { - Range to Target: } 7.70 \text { Meters } \\
\text { - Fish Height: } 3.24 \text { Meters } \\
\text { - Heading: 0.000 degrees } \\
\text { - Event Number: } 0 \\
\text { - Water Depth: } 0.00 \\
\text { - Line Name: BF_120531163600 }\end{array}$ & $\begin{array}{l}\text { Dimensions } \\
\text { Target Height: }=0.0 \text { Meters } \\
\text { Target Length: } 0.0 \text { Meters } \\
\text { Target Shadow: } 0.0 \text { Meters } \\
\text { Target Width: } 0.0 \text { Meters } \\
\text { Mag Anomaly: } Y \\
\text { Avoidance Area: } \\
\text { Classification 1: range light } \\
\text { Classification 2: } \\
\text { Area: } \\
\text { Block: } \\
\text { Description: }\end{array}$ \\
\hline
\end{tabular}




\begin{tabular}{|c|c|c|}
\hline Contact Image & Contact Info & User Entered Info \\
\hline 'i ', & $\begin{array}{l}\text { S07 } \\
\text { - Sonar Time at Target: 05/31/2012 16:34:37 } \\
\text { - Click Position (Projected Coordinates) } \\
\text { (X) } 328217.68 \text { (Y) } 3248773.75 \\
\text { - Map Proj: UTM83-15 } \\
\text { - Acoustic Source File: J:IProjects|2784_12051S } \\
\text { T\&M Bolivar } \\
\text { Ferry_AmaTerra_TX_JMEISSSIBF_120531163000. } \\
\text { sdf } \\
\text { - Ping Number: } 42133 \\
\text { - Range to Target: } 16.14 \text { Meters } \\
\text { - Fish Height: } 3.02 \text { Meters } \\
\text { - Heading: 0.000 degrees } \\
\text { - Event Number: } 0 \\
\text { - Water Depth: } 0.00 \\
\text { - Line Name: BF_120531163000 }\end{array}$ & $\begin{array}{l}\text { Dimensions } \\
\text { Target Height: }=0.0 \text { Meters } \\
\text { Target Length: } 4.8 \text { Meters } \\
\text { Target Shadow: } 0.0 \text { Meters } \\
\text { Target Width: } 1.9 \text { Meters } \\
\text { Mag Anomaly: Y } \\
\text { Avoidance Area: } \\
\text { Classification 1: unknown } \\
\text { Classification 2: } \\
\text { Area: } \\
\text { Block: } \\
\text { Description: }\end{array}$ \\
\hline . & $\begin{array}{l}\text { S08 } \\
\text { - Sonar Time at Target: 05/31/2012 16:40:07 } \\
\text { - Click Position (Projected Coordinates) } \\
\text { (X) } 327865.79 \text { (Y) 3248835.79 } \\
\text { - Map Proj: UTM83-15 } \\
\text { - Acoustic Source File: J:IProjects|2784_12051S } \\
\text { T\&M Bolivar } \\
\text { Ferry_AmaTerra_TX_JMEISSSIBF_120531163600. } \\
\text { sdf } \\
\text { - Ping Number: } 52007 \\
\text { - Range to Target: } 16.47 \text { Meters } \\
\text { - Fish Height: } 3.20 \text { Meters } \\
\text { - Heading: 0.000 degrees } \\
\text { - Event Number: } 0 \\
\text { - Water Depth: } 0.00 \\
\text { - Line Name: BF_120531163600 }\end{array}$ & $\begin{array}{l}\text { Dimensions } \\
\text { Target Height: }=0.0 \text { Meters } \\
\text { Target Length: } 1.6 \text { Meters } \\
\text { Target Shadow: } 0.0 \text { Meters } \\
\text { Target Width: } 0.7 \text { Meters } \\
\text { Mag Anomaly: N } \\
\text { Avoidance Area: } \\
\text { Classification 1: crab pot } \\
\text { Classification 2: } \\
\text { Area: } \\
\text { Block: } \\
\text { Description: }\end{array}$ \\
\hline
\end{tabular}




\section{Appendix E \\ Bolivar Ferry Dredge Expansion Project Engineering Schematics}




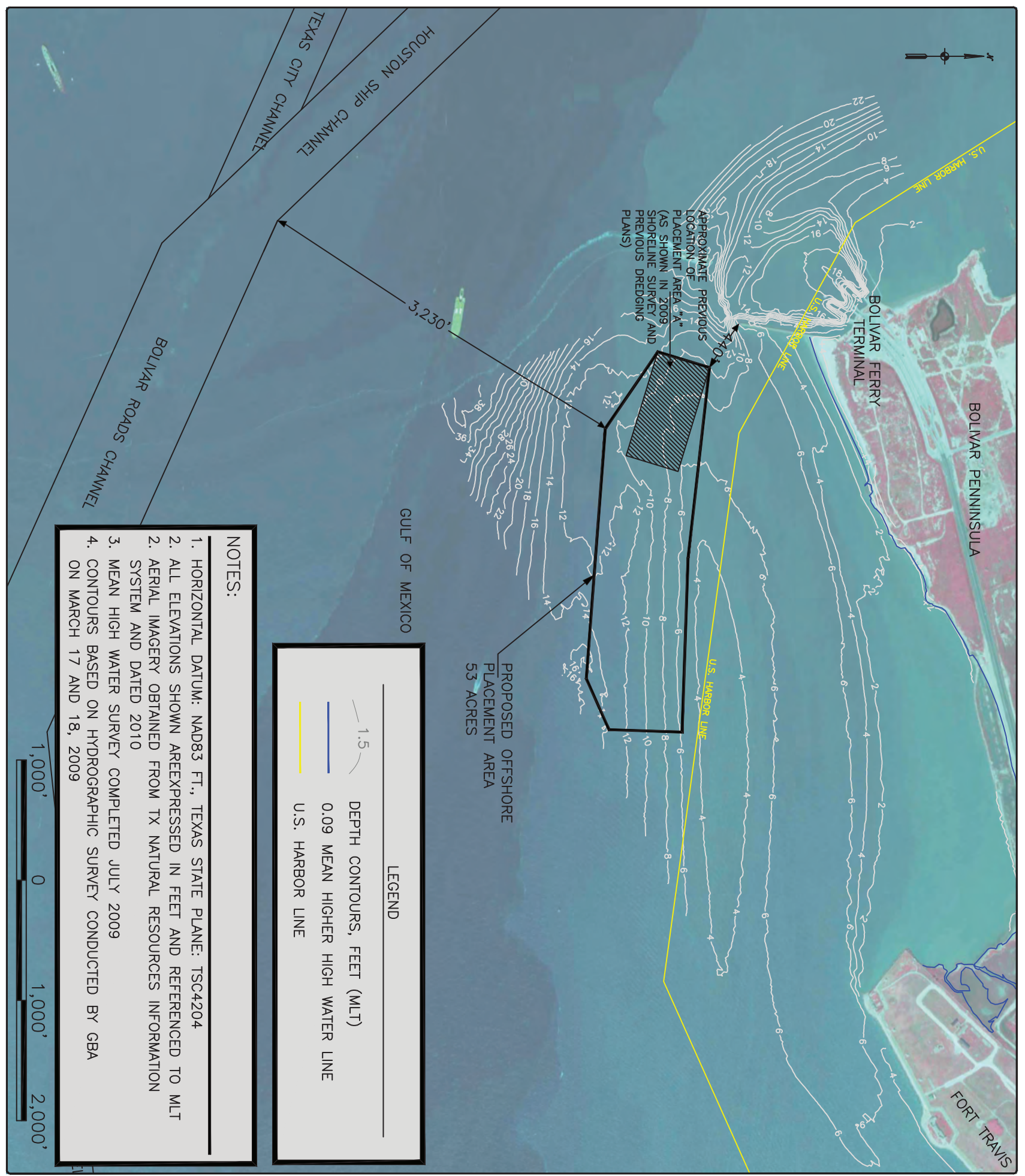

\begin{tabular}{|c|c|c|c|c|c|}
\hline \multirow{2}{*}{\multicolumn{3}{|c|}{$\begin{array}{l}\text { APPLICANT: TEXAS DEPARTMENT OF TRANSPORTATION } \\
\text { PROJECT: BOLIVAR FERRY }\end{array}$}} & \multirow{4}{*}{ 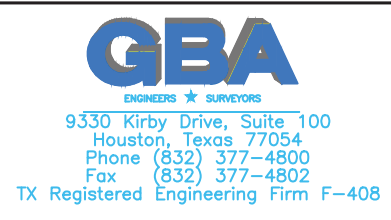 } & \multicolumn{2}{|c|}{ FOR COE USE ONLY } \\
\hline \multirow{2}{*}{\multicolumn{3}{|c|}{$\begin{array}{l}\text { PROJECT: BOLIVAR FERRY } \\
\text { DREDGED MATERIAL PLACEMENT AREA "A" }\end{array}$}} & & Permit Applicant \#: & \\
\hline & & & & Applicant Name: & \\
\hline & $\begin{array}{l}\text { COUNTY: GALVESTON } \\
\text { A-Permit.drg }\end{array}$ & REV. DATE & & SCALE: AS INDICATED & SHEET 1 OF 4 \\
\hline
\end{tabular}




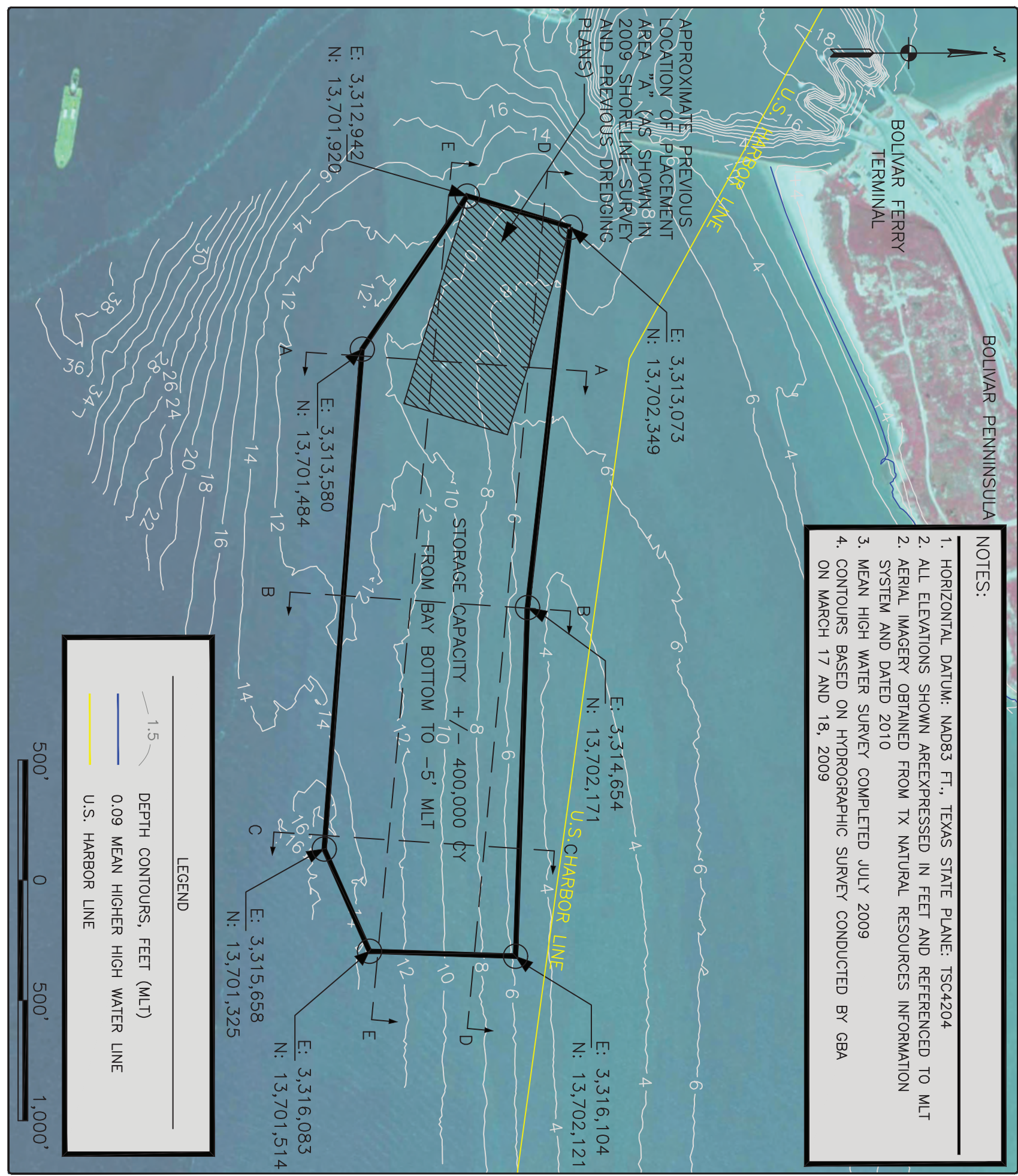

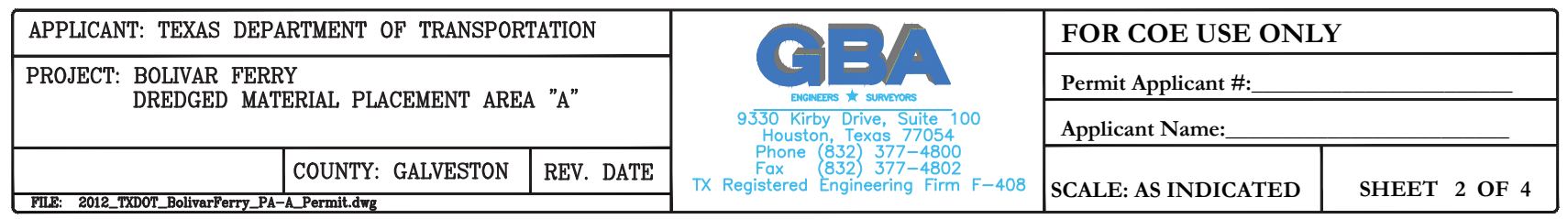




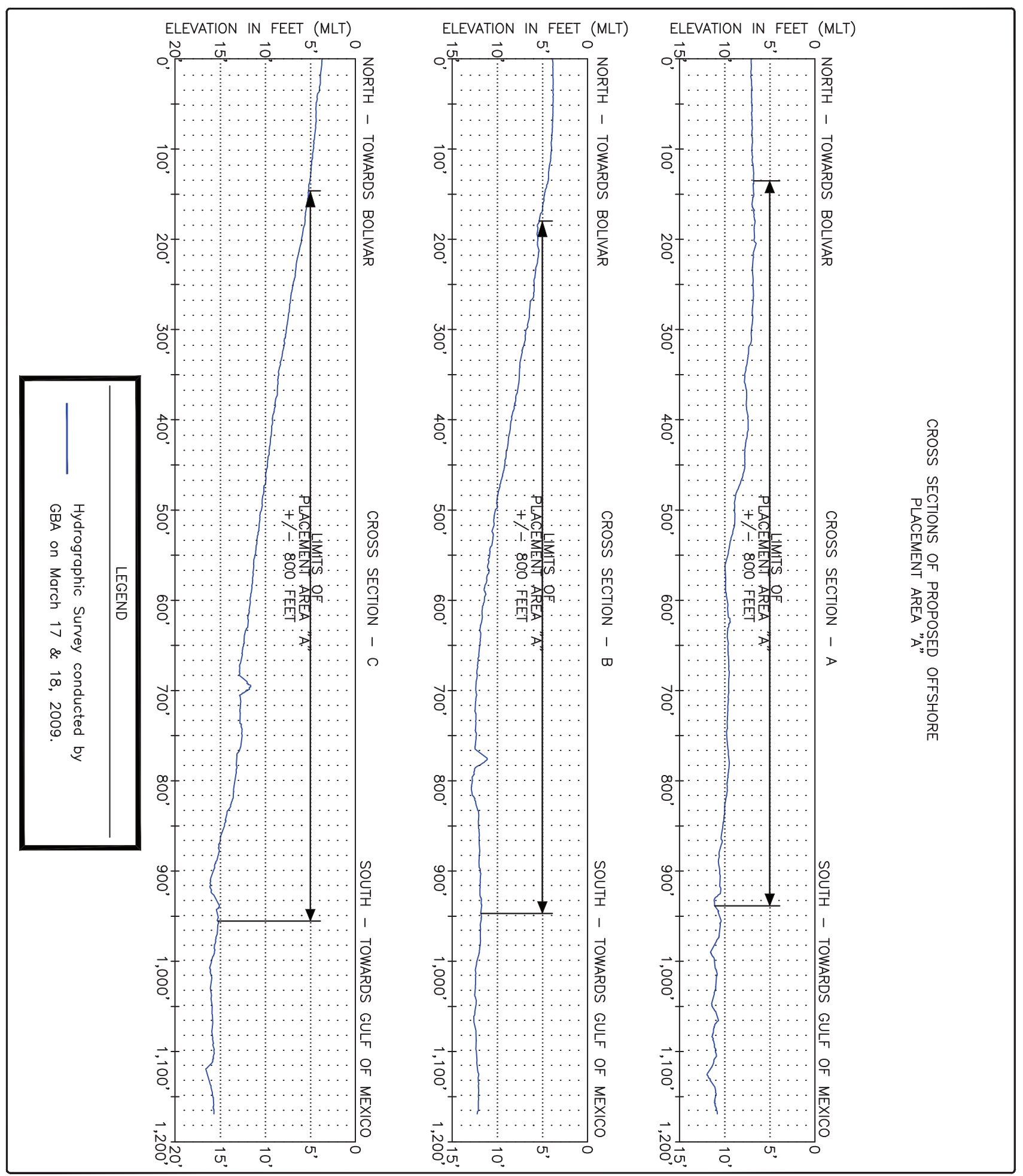

\begin{tabular}{|c|c|c|c|c|c|}
\hline APPLICANT & RTMENT OF TRANSPOR & ATION & & FOR COE USE ON & \\
\hline PROJECT: & 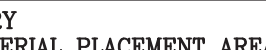 & & & Permit Applicant \#: & \\
\hline & & & $\begin{array}{l}93 \overline{3} \text { Ko Kirby Drive, Suite } \\
\text { Houston, Texas } 77054\end{array}$ & Applicant Name:- & \\
\hline & COUNTY: GALVESTON & REV. DATE & $\begin{array}{l}\text { FX Registered Engineering Firm F-408 } \\
\text { Ex }\end{array}$ & SCALE: AS INDICATED & SHEET 3 OF 4 \\
\hline
\end{tabular}



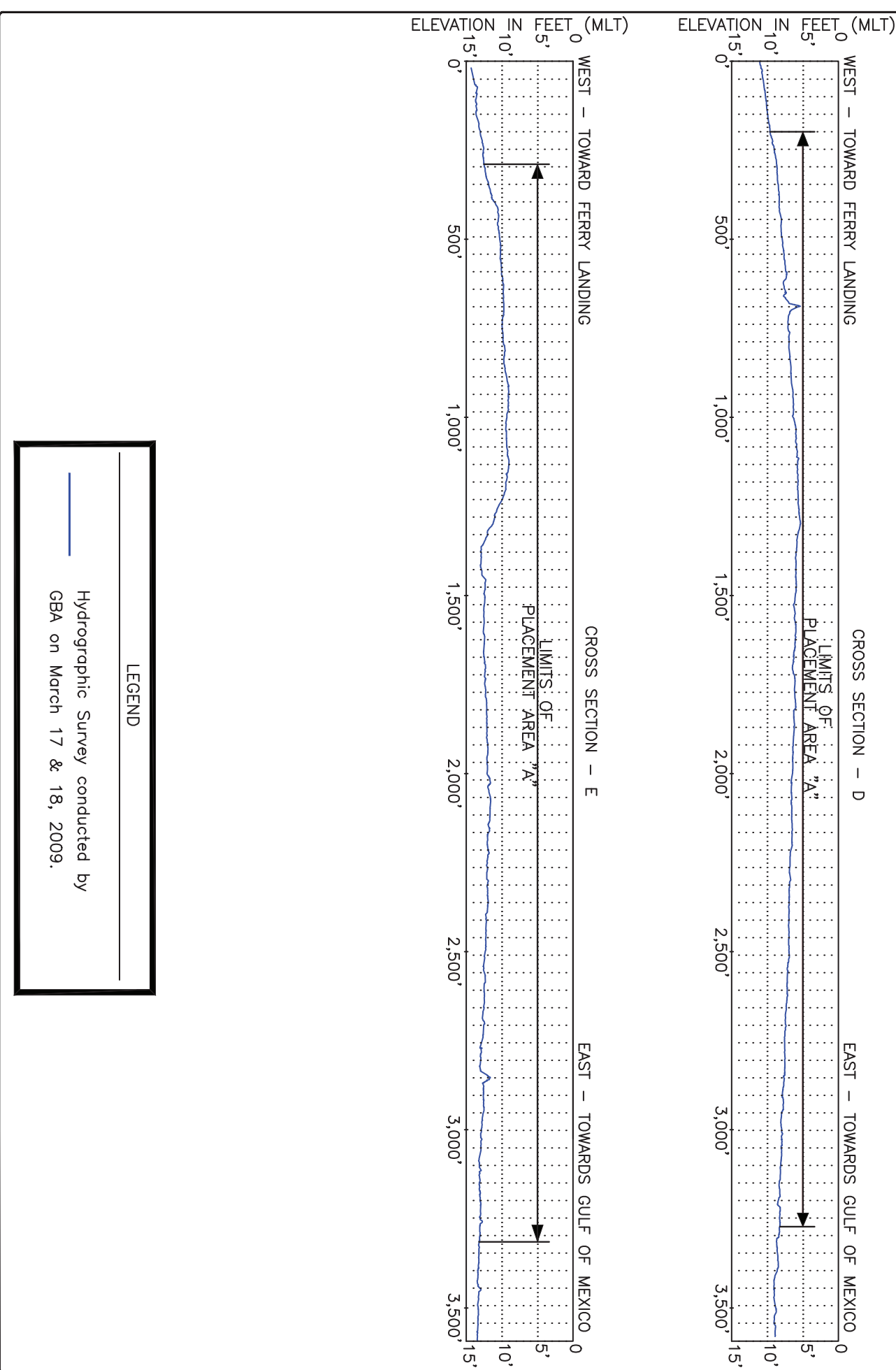

\begin{tabular}{|c|c|c|c|c|}
\hline \multicolumn{2}{|c|}{ APPLICANT: TEXAS DEPARTMENT OF TRANSPORTATION } & \multirow{4}{*}{$\begin{array}{l}\text { Eunewers * suwneros } \\
9330 \text { Kirby Drive, Suite } 100 \\
\text { Houston, Texas } 77054 \\
\text { Phone (832) } 377-4800 \\
\text { Fax (832) 377-4802 } \\
\text { TX Registered Engineering Firm F-408 }\end{array}$} & \multicolumn{2}{|c|}{ FOR COE USE ONLY } \\
\hline \multirow{2}{*}{\multicolumn{2}{|c|}{$\begin{array}{l}\text { PROJECT: BOLIVAR FERRY } \\
\text { DREDGED MATERIAL PLACEMENT AREA "A" } \\
\text { CROSS SECTIONS }\end{array}$}} & & \multirow{2}{*}{\multicolumn{2}{|c|}{$\begin{array}{l}\text { Permit Applicant \#: } \\
\text { Applicant Name: }\end{array}$}} \\
\hline & & & & \\
\hline COUNTY: GALVESTON & REV. DATE & & SCALE: AS INDICATED & SHEET 4 OF 4 \\
\hline
\end{tabular}


